\title{
TRABALHO AGRICOLA DO MENOR NA CAFEICULTURA E SUA INTERFERENNCIA NO PROCESSO EDUCATIVO
}

MARTHA PEREGRINO DA SILVA

Orientadora: Dra. MARIA IGNEZ GUERRA MOLINA

Dissertação apresentada à Escola Superior de Agricultura "Luiz de Queiroz", da Universidade de São Paulo, para obtenção do título de Mestre em Agronomia - Área de Concentração em Sociologia Rural.

\footnotetext{
$P \mid R A C I C A B A$

Estado de São Paulo - Brasil

1983
} 
- ii.

A memōria de meus pais

Aos meus irmãos

A criança brasileira 
Ä Professora Doutora Maria Ignez Guerra Molina, pela orientação, incentivo, observações, crîticas e suges tões e, sobretudo, pelo interesse com que acompanhou cada fase deste trabalho.

A Professora Doutora Maria de Lourdes T.B. Wiendl, pelas sugestões e cuidadosas críticas apresentadas na leitura dos originais.

Ao Professor Doutor José Molina Filho, pelas sugestões e valiosa crítica às análises feitas em relação às Unidades de Produção Agrícola e pela interpretação de sua pro posta de classificação, na leitura dos originais.

A Professora e amiga, Benedita de Camargo Barros, pela dedicação com que acompanhou cada minúcia deste tra balho, em suas diferentes etapas e por sua colaboração eficien te na coleta de dados.

A Professora Lygia P. Morales, pelo apoio que viabilizou a Pesquisa de Campo.

Às minhas irmãs Margarida e Esmeralda, pelo apoio no desenvolvimento da Pesquisa e auxílio indispensável às necessicades inerentes à elaboração final desta dissertação. 
Ao Sr. Delegado de Ensino e aos Professores das Escolas Rurais de Osvaldo Cruz, por sua pronta e efetiva colaboração.

Aos Srs. Edmilson Carlos Romanini e José Martins iveto, pela colaboração desinteressada e eficaz durante a coleta de dados.

Aos Srs. Engenheiros Agrônomos, Drs. Fäbio Cos ta Couto, da Delegacia Agrícola e Luiz Armando Gasparetti, res ponsävel pela Casa da Agricultura em Osvaldo Cruz, pelo apoio dispensado e informações apresentadas.

Aos responsáveis pela Unidades Produtivas Agri colas, às Familias e aos Menores trabalhadores que, com suas informações e acolhimento aberto e compreensivo, contribuiram e facilitaram a coleta de dados.

A todos aqueles que direta ou indiretamente con tribuiram para a concretização do presente trabalho. 


\section{INDICE}

pāgina

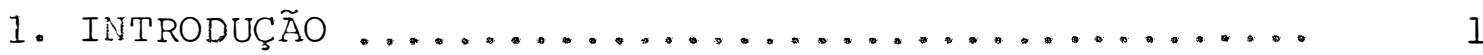

2. O PROBLEMA E SUA IMPORTÂNCIA ................. 7

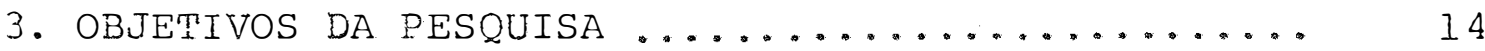

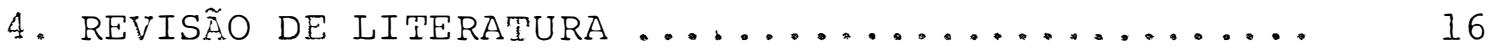

4.1. Trabalho do Menor na Agricultura ......... 16

4.2. Educação e/ou Escolarização e trabalho Rural

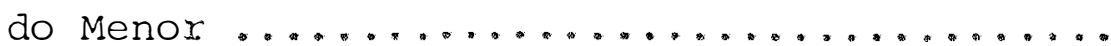

5. ORIENTAÇÃO TEO̊RICA E HIPŌTESES DA PESQUISA ...... 54

5.1. Referencial reórico .................. 54

5.2. Explicitação dos Conceitos ............. 56

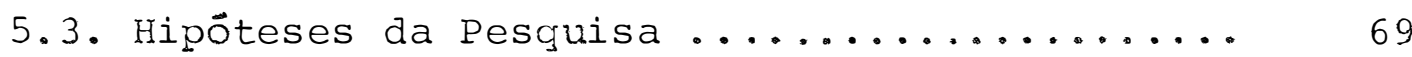

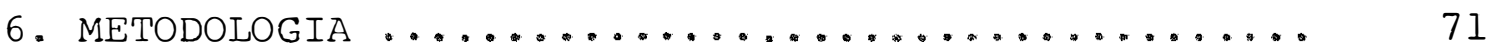

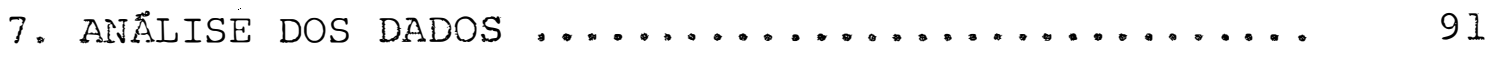

7.1. Breves Considerações Sobre a Area da Pesquisa $\ldots \ldots \ldots \ldots \ldots \ldots \ldots \ldots \ldots \ldots \ldots \ldots . . . \ldots \ldots$

7.2. Anālise dos Dados e Verificação da Hipóteses 98

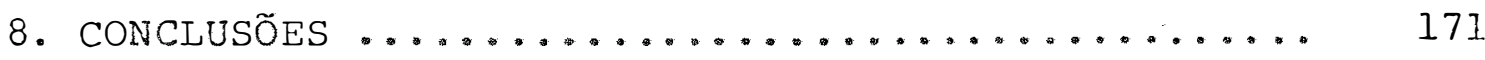

9. BIBLIOGRAFiA CitAdA E CONSULtadA ............ 176

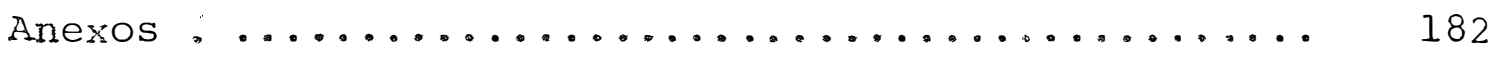


LISTA DE QUADROS

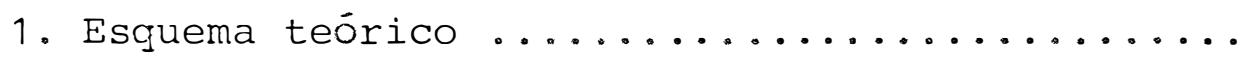

2. V.C. (Unidades Produtivas Agricolas) _ H.1. ..

3. Dimensões das Unidades Produtivas da Anostra Municipio de Osvaldo Cruz - SP - $1981 \ldots . .$. .

4. Categoria dos Produtores por UPAs cafeicultoras - Município de Osvaldo Cruz - SP - 1981 ..

5. Proprietários da Amostra possuidores de outras UPAs no Município, fora dele ou fora do Estado - Municipio de Osvaldo Cruz - SP - 1981 .....

6. Unidades Produtivas Cafeicultoras - Município de Osvaldo Cruz - SP - $1981 \ldots \ldots \ldots \ldots \ldots$

7. Utilização da mão-de-obra Infanto-Juvenil nas UPAs Cafeicultoras - Municipio de Osvaldo Cruz - SP - 1981

8. Mão-de-obra utilizada nas Empresas Agrícolas Capitalistas - Município de Osvaldo Cruz - SP -

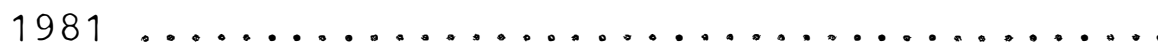

9. Mão-de-obra utilizada nas Empresas Familiares - Municipio de Osvaldo Cruz - SP - 1981 ...... 105

10. Mão-de-obra utilizada nas Unidades Familiais Pré-Empresariais - Município de Osvaldo Cruz -

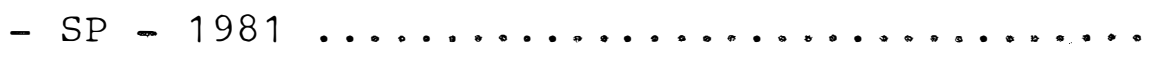


11. Mão-de-obra utilizada nos diferentes tipos de UPAs Cafeicultoras - Município de Osvaldo Cruz -

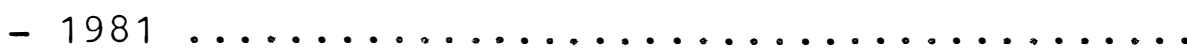

12. Mão-de-obra utilizada nas uPAs Cafeicultoras -Município de Osvaldo Cruz - SP - 1981 ....... 108

13. Utilização da Força-de-trabalho dos Menores nas UPAs Cafeicultoras, segundo a faixa etária dos Menores e segundo o tipo de Trabalho - Município de Osvaldo Cruz - SP $-1981 \ldots \ldots \ldots \ldots \ldots$

14. Menores que desempenhavam tarefas agrícolas nas diferentes UPAs cafeicultoras, segundo a faixa etária - Município de Osvaldo Cruz - SP - 1981 .

15. Nível Salarial de Adultos e Menores em UPAs Cafeicultoras - Município de Osvaldo Cruz - SP 198

16. Categorias Laborais dos Pais ou Responsáveis por Menores que, em idade escolar, desempenhavam tarefas agrícolas - Município de Osvaldo Cruz - SP - 1981

17. Trabalho dos lienores pertencentes às Familias En trevistadas - Município de Osvaldo Cruz - SP 1981 
18. Desempenho de atividades agrícolas entre a popu lação de menores das familias entrevistaảas Município de Osvaldo Cruz - SP - $1981 \ldots \ldots \ldots 118$

19. Relação entre a utilização do trabalho do menor e as Relações Sociais de Trabalho dos Pais - Mu nicípio de Osvaldo Cruz - SP - $1981 \ldots \ldots \ldots$.... 119

20. Matrículas nas Escolas Isoladas e de Emergência - Município de Osvaldo Cruz - SP - 1981 .......

21. Frequência dos contatos da familia rural com o meio urbano - Município de Osvaldo Cruz - SP $-1981$

22. Justificativas apresentadas pelo agricultor para explicar seus contatos com o meio urbano Município de Osvaldo Cruz - SP - $1981 \ldots \ldots \ldots$

23. Aspirações da população rural em relação à possibilidade de residência na cidade - Município de Osvaldo Cruz - SP - $1981 \ldots \ldots \ldots \ldots \ldots \ldots 136$

24. Justificativas apresentadas pela população rural com referência às aspirações relativas ao desejo de residir na cidade - Município de Osvaldo Cruz - SP - $1981 \ldots \ldots \ldots \ldots \ldots \ldots$. . . 
25. Justificativas apresentadas pela população rural referentes ao desejo de permanecer no próprio meio - Município de Osvaldo Cruz - SP -

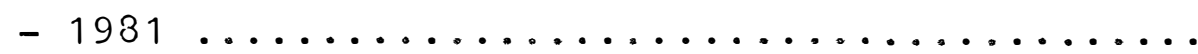

26. Escolaridade na Familia Rural de UPAs Cafeicultoras - Município de Osvaldo Cruz - SP - 1981.

27. Motivos que levaram os Pais a enviarem os fiIhos à Escola - Município de Osvaldo Cruz - SP

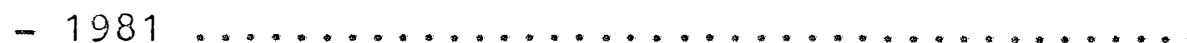

28. Aspirações dos pais em relação à continuidade do estudo dos filhos - Município de Osvaldo Cruz - SP $-1981 \ldots \ldots \ldots \ldots \ldots \ldots \ldots \ldots \ldots \ldots \ldots \ldots$

29. Aspirações dos Pais em relação à futura profissão dos filhos - IIunicipio de Osvaldo Cruz - SP $-1981$

30. Aspirações Profissionais dos Menores Trabalhado res - Município de Osvaldo Cruz - SP - 1981 ...

31. Juizos de valor dos alunos das Escolas Rurais sobre a vida na roça e na cidade - Município de Osvaldo Cruz - SP - $1981 \ldots \ldots \ldots \ldots \ldots \ldots \ldots$

32. Preferências Profissionais dos Alunos do meio rural - Município de Osvaldo Cruz -. SP - 1981 . 
33. Tempo de nomeação dos professores para regerem classes nas Escolas visitadas - Municipio de Osvaldo Cruz $-\mathrm{SP}-1981 \ldots \ldots \ldots \ldots \ldots \ldots \ldots \ldots \ldots$

34. Causas da evasão escolar dos Menores Trabalhadores Agrícolas - Municipio de Osvaldo Cruz - SP -

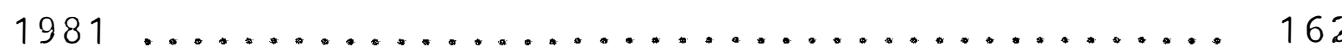

35. Expetativas dos Menores Trabalhadores em relação ao retorno à Escola - Município de Osvaldo Cruz-

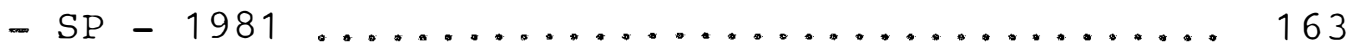

36. Razões atribuidas pelos Pais para a evasão escolar definitiva dos filhos - Municipio de Osvaldo

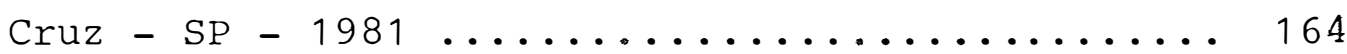

37. Contato dos Pais com os Professores - Município de Osvaldo Cruz - SP $-1981 \ldots \ldots \ldots \ldots \ldots \ldots$

38. Frequência dos Pais à Escola dos Filhos - Municí pio de Osvaldo Cruz - SP - $1981 \ldots \ldots \ldots \ldots \ldots \ldots$ 
TRABALHO AGRICOLA DO MENOR NA CAFEICULTURA

E SUA INTERFERENCIA NO PROCESSO EDUCATIVO

Autor: MARTHA PEREGRINIO DA SILVA

Orientador: Dra. MARIA IGNEZ GUERRA MOLINA

RESUMO

Voltado para a relação "trabalho agrícola-esco larização" este estudo procurou analisar a utilização da mão-de-obra infanto-juvenil e suas consequências para a escolari zação do menor no meio rural.

Realizou-se uma pesquisa empírica em um municí pio cafeicultor, no Estado de São Paulo para verificar, nessa cultura, a intensidade e as formas de utilização da mão-de-obra infanto-juvenil nos diferentes tipos de Unidades Produtivas Agrícolas.

Teve-se como pressuposto básico que o atual contexto do País obriga a familia rural a incorporar o trabalho dos filhos menores à sua força de trabalho, o que já foi institucionalizado pelas estatísticas censitárias que incluem na população econômicamente ativa da agricultura os menores 
que trabalham, a partir dos 10 anos, remunerados ou não.

Verificou-se que a mão-de-obra infanto-juvenil è habitualmente utilizada em todos os tipos de Unidades Prodụ tivas na cafeicultura da região e em quase todas as tarefas agrícolas nela desempenhadas. Sua participação no trabalho familiar mostrou-se acentuada e crescente.

Verificou-se também que o Estado investe na Es cola Rural equipando-a de material e pessoal, mas orienta o processo ensino-aprendizagem definindo os conteúdos programäticos, direcionando suas metas, ainda que o faça sem obrigar os agentes, cuja formação também define.

Veiculando interesses urbanos a Escola Rural, servindo ao meio, o nega. Consciente ou inconscientemente difunảe valores que motivam expetativas urbanas, estimulando o êxodo rural, no que é coadjuvada pelos meios de comunicação e pela interação campo-cidade.

Não se pode afirmar que exista entre os profes sores a consciência do que sua ação representa no meio rural, mas é possível concluir, pelos dados da pesquisa, que a Escola nesse meio serve à preparação de futuros trabalhadores que, proletarizados, venham a se constituir no chamado exército de reserva exposto à exploração do capital industrial. 
THE PARTICIPATION OF MINORS IN COFFEE CROPPING AND

ITS INTERFERENCE IN THEIR EDUCATIONAL PROCESS

Author: MARTHA PEREGRINO DA SILVA

Adviser: Dra. MARIA IGNEZ GUERRA MOLINA

SUMMARY

Based on the "agricultural work/schooling" relationship, an attempt was made in this study to analyze the use of infant-juvenile labor and its reflections on the schooling of minors in the rural setting.

An empirical research was carried out in a coffee growing municipality in the state of são Paulo to assess the intensity and forms of infant-juvenile labor employment for this crop in the different types of Agricultural Proâctive Units.

The basic assumption was that the country's present context impels the rural families to incorporate the work of their younger children into their labor force. This has been institutionalized in censor statistics which have included these working minors (from 10 years of age, whether 
wage earners or not) as part the economically active agricultural population.

It was observed that infant-juvenile labor is utilized in all types of coffee cropping productive units in the region, as well as in almost all agricultural tasks carried out in these units. Whe participation of infants-juveniles in the family's work was show to be increasing and pronounced.

It was also observed that the state invests in Rural Schools, providing supplies and personnel, but orients the teaching-learning process by defining the program content and directing its goals, even though the agents (whose education is also defined by the state) are not obliged.

By disseminating urban interests, the rural schools, while, serving their environment, are denying it. Either consciously or unconsciously, it disseminates values that motivate urban expectations, stimulating rural exodus, with the help of the communication media and field-city interaction.

It cannot be stated the teachers are conscious of what their activities represent in the rural setting, however, based on research results it is possible to conclude that the rural school prepares future workers who, proletarianized, eventually will compose the so-called reserve army, exposed to the exploitation of the industrial capital. 
1. INTRODUCAO

O presente estudo voltou-se inicialmente para o trabalho do menor no meio rural, tendo como objetivo verifi car o grau ou extensão da exploração da mão-de-obra agrícola infanto-juvenil.

Partiu-se do pressuposto de que o processo de capitalização na agricultura brasileira apresenta graus diver sos de desenvolvimento nas diferentes regiões do País, podendo manifestar várias formas de exploração da terra nas quais o trabalho infanto-juvenil seria explorado com maior ou menor intensidade.

Iniciados os estudos em questão, observou-se que o trabalho do menor no meio rural não pode ser analisado isoladamente. Além da problemática mais abrangente do contex to sócio-econômico, no qual se insere o trabalho agrỉcola do menor, condicionando-o, ficou evidente a intima relaçẽo trabạ 
lho agrícola e educação sistemática ou escolarização do menor no meio rural.

Existem muitas controvérsias a respeito do papel da Escola nesse meio, e da interferência do trabalho agri cola no processo educativo do menor.

Alguns autores, analisando o sistena global de ensino, responsabilizam o Estado pela situação educacional precária no meio rural; outros veem na problemática econômico-so cial do Pais a causa das dificuldades da Escola nesse meio.

Entre aqueles que estudaram a situação do menor no meio rural, distinguem-se os que enfatisam o problema da escolarização e os que dão maior destaque à q̧uestão do trabalho. Uns e outros se deparam com a mesma relação trabalho rural e educação sistemática ou escolarização do menor.

Estas consideraçōes motivaram a reorientação do enfoque da pesquisa, o qual passou a ser definido como "Tra balho Agrícola do Menor na Cafeicultura e sua Interferência no Processo Educativo".

o trabalho foi estruturado a partir do levanta mento do problema e da revisão da literatura existente sobre temas relacionados com a questão.

A primeira fase da revisão possibilitou: 
a. dimensionar o problema em seus diferentes aspectos;

b. definir os objetivos da pesquisa;

c. especificar as hipóteses do trabalho.

A segunda fase possibilitou fosse estabelecido o referencial teórico que deveria orientar a pesquisa. Este foi definido através de quatro conceitos fundamentais:

1. o conceito de Unidades Produtivas Agrícolas (UPAs);

2. o de Relações Sociais de 'Trabalho;

3. o de Relação Campo-Cidade; e

4. o de Institucionalização e Organização do Ensino.

Os conceitos 1 e 2 pareceram necessārios, uma vez que o estudo do problema tinha como unidade de anālise o MENOR, cujo processo educativo se supunha prejudicado pelo trabalho agrícola realizado em UPAs cafeeiras, através de pos siveis e diferentes Relasões Sociais de Trabalno.

Os conceitos 3 e 4 foram destacados em razão dos próprios objetivos do estudo, tendo-se por pressuposto que a Relacão Campo-Cidade interfere também no processo educa tivo do menor, sendo este condicionado à organizasão do Ensino Rural.

Definido o referencial teórico, passou-se a es tabelecer os caminhos da Pesquisa, o que levou à elaboração do Modelo Conceitual, instrumento útil, embora não indispensâ vel. 
A Pesquisa foi realizada em um Municipio situa do em uma das sub-regiões da Divisão Regional Agrícola de Pre sidente Prudente, a qual encontra-se sub-dividida nas Sub-Regiões de Presidente Prudente, Martinópolis, Osvaldo Cruz, Dra cena e Presidente Venceslau. A Sub-Região de Osvaldo Cruz, na qual se encontra a área da Pesquisa, abrange os Municípios de Osvaldo Cruz (sede sub-regional), Adamantina, Flórida Paulista, Lucélia, Mariápolis, Parapuã, Rinópolis e Salmorão.

Foi escolhido o Município-sede da Sub-Região de Osvaldo Cruz por se considerar que o mesmo apresentava con dições significativas,com suas 777 UPAs distribuidas em uma ārea de 24.098 ha.

Sabe-se que houve aumento na utilização do trạ balho de menores na agricultura no período $70 / 75$, nas micro-regiões da Alta Sorocabana e de Presidente Prudente, na qual está inserida a sub-região de Osvaldo cruz.

Em 1970, nesses duas DIRAS, 13.631 menores tra balhavam na lavoura. O nümero elevou-se, em 1975, para 17.243, o que representa um aumento de 3.612 menores.

A cafeicultura constitui-se em um tipo de cultura permanente que exige, além de outras mais pesadas, a exe cução de tarefas agrỉcolas consideradas leves (*). No desem-

(*) São consideradas leves na região, além da colheita do café, a arruação, a esparramação e até mesmo a adubação do solo para o plantio do café. Também são consideradas leves a capina., a colheita e adubação do solo para as lavouras intercalares. 
penho dessas tarefas são ocupadas a mão-de-obra infanto-juvenil e a feminina, o que diminui sensivelmente o custo operacional da produção pela depreciação dos salários da mulher e do menor e, sobretudo, pela maior utilização do trabalho familiar.

Considerando-se que o menor é mais ocupado na lavoura do que na pecuária e que, entre os produtos cultivados na região o café se destaca como produto principal, ocupando a maior parte das terras cultivadas, concluiu-se que o estudo na área poderia trazer ponderáveis contribuições em re lação ao problema.

E pertinente observar que a região conta com o maior e mais compacto bloco de café do Estado de são Paulo, segundo monografia mimeografada do Municipio (1978), fornecida pela Prefeitura de osvaldo cruz, o que também justifica a escolha da área geográfica para a Pesquisa. A viabilidade foi outro dado que interferiu na opcão, condicionada aos recursos e ao tempo disponiveis.

No presente trabalho é feita inicialmente a co locação geral do problema e de sua importância. A seguir são definidos os objetivos gerais e especificos da pesquisa. Fez -se, então, a revisão bibliográfica sob dois enfoques: "Traba Iho do Menor na Agricultura" e "Educação e/ou Escolarização do Menor no meio Rural". Segue-se o Modelo Teórico, fundamen tado nas reflexões despertadas pela revisão da Literatura, ex 
plicitando os conceitos utilizados e as hipóteses que orienta ram o trabalho.

Na apresentação da Metodologia seguida foram colocados os procedimentos gerais e o Modelo Conceitual, com a definição das variáveis a serem analisadas para verificação das hipóteses. A demoinstração destas é iniciada com breves considerações sobre a área da Pesquisa, seguida da Análise dos dados e das conclusões do trabalho.

Não se pretende ter esgotado o tema. Acredita-se, entretanto, que o estudo feito possa contribuir para aju dar sociólogos, educadores, trabalhadores sociais e demais técnicos envolvidos com o problema e oferecer subsídios para os planejadores da Política Social e Educacional do País e so bretudo da Região. 
Entre as preocupações da moderna sociedade ociㅗ dental, aquelas que dizem respeito ao menor são consideradas como responsabilidade da Família e do Estado. Destacam-se, entre outras, as preocupações com o trabalho infanto-juvenil e com a educação do menor.

A história revela que o trabalho infanto-juvenil tem sido usado a favor de forças econômicas pressionadoras. Na Inglaterra, a partir da revolução industrial, crianças de 5 anos trabalhavam cerca de onze a dezesseis horas por dia, cozendo luvas. Foi também aí que apareceu, pela primeira vez, a reação em defesa do menor trabalhador atravēs da voz dos operários e de alguns parlamentares. Entretanto, ape nas a partir de 1808 foi possivel a conquista do limite de idade para 14 anos. 
A Conferência Internacional do Trabalho, reuni da em Gèneve em 1921, devem-se os primeiros esforços para regulamentar o uso do trabalho de menores na agricultura. Ao Convênio que então se firmou aderiram poucos paises. Esse con vênio procurava controlar o limite de idade de ingresso do me nor no trabalho agrícola através da regulamentação da frequên cia escolar.

A IV Conferência dos Estados da América, reali zada em 1949 em Montevidéu, explicitou recomendações para o estabelecimento de leis e regulamentos nacionais que fixassem a idade minima legal de admissão ao trabalho, reconhecendo, porém, a validade de um limite mais baixo em relação às ativi dades agrỉcolas.

No Brasil as leis que fixaram as normas a respeito do trabalho infanto-juvenil datam de 1891. A lei 1313, que se referia ao trabalho do menor em geral, proibia a sua ocupação noturna em certos serviços e limitava ao máximo de 7 horas a jornada de trabalho dos menores de 12 a 15 anos, para o sexo feminino, e de 12 a 14 , para o masculino.

A Constituiqão Federal de 1934, em seu artigo 121, letra d, proibiu o trabalho do menor que não tivesse atingido 14 anos. Mantida a proibição pela Constituição de 1937 (artigo 137, letra k), houve um retrocesso na Constitui\&ão de 1946 que, em seu artigo 157, inciso IX, mantendo embo- 
ra a idade minima de 14 anos, permitia o trabalho do menor, uma vez "respeitadas em qualquer caso, as condições estabelecidas em lei e as exceções admitidas pelo Juiz competente."

A Constituigão de 1967 recuou ainda mais e a emenda de 1969, no artigo 165, inciso XV, confirmou o limite previsto em 1967 para 12 anos, conquanto imponha o ensino obrigatório dos 7 aos 14 anos. A nova organização do ensino, instituindo o Ensino de Primeiro Grau, integrando o primário e o antigo ginásio, leva a estender este período até os 15 anos.

A C.L.T. (Consolidação das Leis do Trabalho 1943), em seu artigo 403 confirma o limite de 12 anos e estabelece como condições que, ao menor dos 12 aos 14 anos:

a. seja garantida a frequência à escola de modo a assegurar a formação em nível primārio;

b. os serviços sejam de natureza leve, não nocivos à saúde e ao desenvolvimento.

O Estatuto do Trabalhador Rural, Lei 4.214 de 02.03.1963 estabelece normas sobre o trabalho do menor. Apre senta, porém, certa ambiguidade porque:

a. não estabelece o limite mínimo de idade;

b. o artigo 11 estabelece e institui "em todo o território nacional, para as pessoas maiores de 14 anos, sem distinção de sexo ou nacionalidade, a carteira profissiom 
nal de trabalhador rural;

c. o artigo 34 trata do direito que tem 0 menor, com mais de 16 anos, a receber salário igual ao salário do adulto e estatui para o menor com menos de 16 anos a metade do salário mínimo pago ao adulto;

d. os artigos 57 e 59 referem-se a menores de 18 anos e com menos de 21 anos respectivamente.

F'ica evidente que a questão do trabalho do menor tem preocupado legisladores, juristas e organizações de trabalho.

Quanto aos estudos sociológicos sobre o assunto, particularmente sobre o trabalho do menor no meio rural,e sua interferência na escolarização e no processo educativo, são raros os trabalhos existentes.

O assunto é relevante, tanto por sua significa ção intrỉseca, quanto pela escassês de pesquisas sociológicas que sirvam de suporte para emendas de leis sobre o trabalho infanto-juvenil ou modificações significativas em sistemas educacionais.

o trabalho que insere o homem no processo geral de produção, sobretudo o trabalho agrícola com suas exigências de ocupação mais ou menos constante, prolongada nos periodos das safras, pode constituir-se em prejuízo para o de senvolvimento físico e intelectual dos menores, obrigando-os 
a atividades não condizentes com sua fase de desenvolvimento físico e mental, forçando-os a um amadurecimento prematuro em relação às responsabilidades sócio-econômicas na sociedade.

Ocupando-se em tarefas sazonais, mesmo leves, o menor afasta-se periodicamente da instituição escolar responsável por sua instrução, afastando-se igualmente da presen ça educativa dos pais, ficando apenas entregue à vigilância de capatazes mais preocupados com a produtividade de trabalha dores do que com a educação de aprendizes.

Interessa à Indústria agrícola na produção capitalista que se vai impondo no meio rural brasileiro, que o trabalho se realize depressa, para que não seja perdida qualquer parcela da colheita. Para se atender às necessidades da safra, o sono da criança é prejudicado, pois ela deve começar mais cedo o serviço. Por outro lado, a tarefa é mais prolongada, apresentando-se com sua característica de repetição e monotonia, conträria aos interesses e necessidades infantis.

A criança precisa de atividades diversificadas, que estimulem as forças de toda a musculatura em desenvolvimento, e conduzam a exercícios de inteligência e de criatividade. Realizando por horas seguidas os mesmos movimentos de colher algodão, café, frutas, etc., o organismo da criança e as faculdades de seu espirito não recebem os estimulos necessãrios ao desenvolvimento normal. Ainda que o trabalho seja 
fácil e, em si mesmo, saudável, porque realizado ao ar livre, torna-se nocivo por sua repetição e continuidade durante longas horas e semanas.

Por outro lado, a criança necessita de ativida des lúdicas e nem sempre é possível ao menor "brincar" durante a tarefa agrícola. Só o é quando cada um trabalha para ga nhar de acordo com a tarefa executada, o que provoca a dilata cão do tempo de trabalho. Quando recebem por dia de trabalho, como ocorre nos períodos de carpa e de colheita do cafe. os menores são vigiados sob o maior cuidado.

o que se pode prever quando o seu trabalho é uma parte do trabalho familiar, contratado este por produtivi dade? ... As leis que proibem o trabalho do menor de anos nada falam quando ele se constitui numa parte da ativida de familiar. Sua participação fica a critério dos pais, e condicionada às exigências da produtividade da família.

O presente estudo tem em vista verificar o pro blema em regĩa caseeira, portanto, de produção voltada para a exportação, na tentativa de incrementar um processo reflexi vo e atento sobre a inserção do menor no trabalho agrícola e no processo geral de produçäo. Pretende ainda contribuir para uma reflexão sobre a organização do ensino no meio rural, pressupondo que a atividade agrícola continuada pode afetar a escolarização e o processo educativo do menor. 
As tarefas agrícolas habitualmente realizadas, se não destroem de todo, podem obstaculizar as tendências naturais do imaturo em seu desenvolvimento:

- tendências que se referem às atividades lúdicas;

- tendências de agrupamento por níveis de idades em torno de interesses condizentes com cada fase infanto-juvenil; tendência espontânea à curiosidade de aprender (necessidade intelectual);

- necessidade do descanso do menor em vista do seu desenvolvi mento;

- necessidades básicas de alimentação suficiente e sistemática, nem sempre atendidas quando o menor desempenha trabalhos que requerem tempo e quase obstinação de vontade. 


\section{OBJETIYOS DA PESQUISA}

\subsection{Objetivo geral}

Analisar a associação entre os diferentes tipos de unidades produtivas existentes na agricultura e a utilização do trabalho do menor num município cafeicultor.

3.2. Objetivos especificos:

3.2.1. Identificar as diferentes formas de utilização do trabalho do menor nos diversos tipos de UPAs.

3.2.2. Verificar as relações sociais de trabalho pre dominantes na cultura cafeeira nas diferentes unidades produtivas e sua possivel influência sobre trabalho e escolarização dos menores pertencentes a famillias de agricultores.

3.2.3. Verificar se as relações cidade-meio rural afe tam e de que maneira a relação trabalho e escolarização no 
meio rural.

3.2.4. Verificar como o Ensino Rural influi no proces so educativo do menor que trabalha na agricultura.

3.2.5. Oferecer subsidios para uma reelaboração da politica afeta ao trabalho e à educação do menor na agricultura. 


\section{REVISÃO DE LITERATURA}

4.1. Trabalho do Menor na Agricultura

KAUTSKY (1968 - 124) refere-se ao emprego de menores na agricultura, em diferentes paises europeus e sobre tudo na Alemanha. Afirma que a utilização do trabalho do me-nor, restringindo sua instrução, aumenta à medida em que a agricultura se racionaliza e à medida em que cresce a concorrência entre a exploração científica do solo e a pequena cultura rotineira.

\section{Observa também como, na pequena propriedade} que ainda resiste ao sistema capitalista de produção, a fruga lidade e o excesso de atividades agricolas extenuam o agricul tor, condenando a um trabalho forçado não apenas o chefe, mas toda a familia. Nessas pequenas unidades exploradas pelo pro prietārio, as crianças estão sempre sujeitas à exploração. 
Um relatório westfaliano citado por KAUTSKY $(1968$ - 123) afirma: "O trabalho das mulheres e dos menores é raramente feito por estranhos e não acarreta, pois, inconveniente de espécie alguma. O das crianças é mesmo muito proveitoso. Mas na maioria das vezes elas são exauridas pelos próprios pais... (...)".

Observa-se em KAUTSKY que a atividade dos meno res causa preocupações acentuadas quando estes exercem atividades agrícolas incluidas no trabalho familiar e quando o fazem a serviço de arrendatários, que os levam a trabalhar em troca de casa e mesa, situação bastante comum no nordeste da Alemanha.

o autor faz importante observação ao estudar o problema do trabalho acessório a que se vê obrigado o agricul tor para suplementar a renda da familia. Quanto mais esse trabalho o ocupa, tanto mais as suas propriedades diminuem e menos ele pode atender às necessidades domésticas. Igualmente, quanto mais o trabalho pago ocupa o primeiro plano, tornando acessório o trabalho doméstico, tanto mais o primeiro absorve o tempo da familia. Habitualmente isto ocorre no momento em que seria necessário que ela empregasse toda a sua energia na exploração da própria gleba, nas fases da colheita. Essa atividade, porém, vai passando gradativamente às mu lheres, aos menores e, às vezes, até aos avós semi-inválidos. 
Um memorial de Hubert Auchagen, sobre a grande e a pequena exploração agrícola, citado por KAUTSKY (1968 - 127-128) informa que o pequeno camponês recebe dos filhos, ainda menores, um auxílio considerável. Estes começam a ajudá-10, não raro, desde que começam a andar. Segundo o relató rio em foco, o camponês empregava no trabalho agrícola todos os seus filhos menores, sem excluir o mais novo que tinha ape nas 7 anos.

Discutindo o problema da Proteção ao Proletariado Agrícola KAUTSKY (1902 - 64/65) lembra que "entre as leis protetoras dos trabalhadores, as mais importantes são aquelas que têm por objeto proteger a geração em crescimento".

Analisando a questão do trabalho assalariado das crianças observa que aquele exerce deploráveis efeitos so bre estas, cujas forças de resistência são menores do que a dos adultos, ressentindo-se mais vivamente de todos os males físicos e morais e sofrendo-lhes as consequências para toda a vida. Explica que, assim como na indūstria, a grande explora ção agrícola criou uma série de trabalhos simples e fáceis, aos quais são atribuidos baixos preços, sendo os mesmos confiados às crianças: amontoar pedras, ajudar nas colheitas, etc.

O autor assinala un ponto importante cquando observa que, na medida em que rareia a oferta de trabalho adulto no cam po, mais se faz sentir a necessidade de introduzir as crianças no 
trabalho. Este, em razão das tarefas mais prolongadas e também mais monótonas, implica na vigilância severa aos menores.

Observa o autor que, embora não se use o traba tho noturno na agricultura, com frequência é abreviado o tempo de repouso das crianças as quais começam, excessivamente cedo, principalmente no verão, a executar essas tarefas.

Nas plantações de beterraba, ligadas às refina rias de açúcar, de cócoras, o corpo inclinado para a frente, fazendo afluir o sangue à cabeça, crianças de 6 a 14 anos eram empregadas durante 12 a 18 horas por dia numa tarefa insuportável para adultos. Depois de várias semanas ocupadas nisso, o retardamento em relação ao desenvolvimento intelectual parece ao autor consequência inevitável e normal.

Segundo KAUTSKY (1968), a agricultura alemã,em 1882 ocupava 291.286 crianças. A estatística oficial, porém, revelou pela primeira vez em 1885 que o número de crianças alemãs que trabalhavam pela subsistência, com menos de 14 anos, era de 214.954; entre elas, 135.125 trabalhavam na agricultura, sendo que 30.604 tinham menos de 12 anos, o que representa 19,9\% do total. O autor observa que tais números eram bas tante irreais, calculando em mais de um milhão o número de crianças efetivamente empregadas em trabalhos de subsistência. Ele não rejeita o trabalho agrícola infantil mas pretende que a proteção à criança em relação ao trabalho não se dirija a 
uma delimitação de idade mínima para o ingresso na atividade agrícola ou em qualquer outra atividade produtiva. Prefere a idéia de se definir tempo de trabalho, opinando que o mesmo seja de 4 horas diārias, incluindo em seu conceito de criança, o menor até os dezoito anos.

Focalizando trabalho-escolaridade no meio rural, destaca-se o estudo de CALDEIRA (1960) o qual, nas suas justificativas, lamenta o fato de que, motivos estranhos à própria vontade, o tenham impedido de executar a pesquisa ori ginalmente programada e a ser realizada em Municípios de gran de expressão agrícola.

Na primeira parte de seu estudo oferece uma vi são geral do trabalho agrícola do menor a nivel internacional. Analisa a situação de países desenvolvidos e de países pobres. observa que o investimento de capitais no setor agrícola, com todo o acervo de tecnologia que pode usar com o emprego de má G'inas, subverte a estrutura de amplas camadas sociais, levan do familias inteiras, cujas propriedades são absorvidas pelas grandes empresas, a alugar a força de trabalho para poderem subsistir. A intensa utilização de maquinärias não permite ou não facilita o trabalho do menor. Considerando isto, CAL DEIRA (1960 - 20) observa que existe estreita relação entre o emprego de menores na agricultura e o nivel de desenvolvimento econômico. Quanto maior este, mais aperfeiçoada serā a 
tecnologia, diminuindo a utilização da mão-de-obra infanto-juvenil. Apesar disto, de acordo com o autor, encontram-se no setor agrícola os maiores efetivos de mão-de-bra infanto-juvenil, no conjunto das diversas regiões do mundo. As informações por ele colhidas o levam a identificar uma tendência à redução do empreço de menores na agricultura, nas socie dades que apresentam uma estrutura agrícola industrializada; ainda assim, em sua totalidade, mesmo os países amplamente in dustrializados utiljzam a mão-de-obra infanto-juvenil, que as segura o trabalho nás empresas familiares e nas explorações que podem utilizar tecnologia tradicional.

Baseado em informes da Organização Internacional do Trabalho o autor observa que, nos Estados Unidos, em 1950, trabalhavam na agricultura cerca de 900.000 menores com menos de 16 anos, entre os quais 447.000 estaram entre 10 e 14 anos; os dados the parecem significativos relativament:e à população rural norte-americana que totalizava, então, sete milhões de pessoas, isto é, $12.8 \%$ dessa população era constituida por menores trabalhadores. Corralacionando desenvolvi mento econômico e emprego de menores na agricultura, concluj. que o reduzido nível de industrialização agrícola imp̣̂ica no aumento do uso do trabalho do menor. Não fundamenta, porể, em estatisticas, esta afjirmação. 
ções legais ao emprego de menores na agricultura e tendo explorado dados relativos à Austrália, Ásia e África, como tanbém referentes a diversos países da Europa, vários Estados da América do Norte e países da América Latina, conclui ser não apenas praticamente impossível a proibição do emprego de mão-de-obra infanto-juvenil na agricultura, fora das horas de en sino como, também, desejável tendo em vista a formação profis sional dos menores.

Julga precária a legislação trabalhista no Bra sil em relação ao trabalhador que se ocupa da agricultura.

$$
\text { Ao tempo em que publicou o seu estudo ainda }
$$
não existia no Brasil o Estatuto do Trabalhador Rural, Lei 4.214, de 02.03.1963, revogado pela Lei 5889 de 08.06.1973, nem o Estatuto da Terra, Lei 4.504, de 30.11.1964. Entretanto, deve-se observar que eles nunca foram, nem o são, aplicados com a devida fidelidade.

O Estatuto da Terra, ao dispôr sobre os imóveis rurais, para os fins de execução de uma possível Reforma Agrária e promoção da Política Agrícola, reconhece a necessidade do atendimento à função social da Unidade Produtiva.

Explicando esta função, mostra que a propriedade da terra a desempenha integralmente quando, simultaneamente:

- favorece o bem-estar dos proprietários e dos trabalhadores que nela labutan, assim como de suas famílias; - observa as disposições legais que regulam as- 
justas relacões de trabalho entre os que a possuem e os que a cultivam.

Reconhece no art. 20, $\S 2$ letra b, ser dever do Poder Público "zelar para que a propriedade da terra desem penhe sua função social, estimulando planos para a sua racional utilização, promovendo a justa remuneracão e o acesso do trabalhador aos beneficios do aumento da produtividade e ao bem estar coletivo".

No Capitulo IV, que trata do uso da posse temporária da Terra, Seção III, artigo 96, inciso VII, § único, a lei afirma: "os contratos que prevejam o pagamento do traba lhador, parte em dinheiro e parte percentual na lavoura cultivada ou gado tratado, são considerados simples locação de serviço, regulada pela legislação trabalhista ..."

PRADO JUNIOR (1963) observa que a atenção prin cipal e quasi única da Reforma Agräria concentrou-se no problema da subdivisão da propriedade fundiāria, com prejuízo de aspetos importantes, como o da legislaça-social-trabalhista aplicada ao trabalhador rural.

Analisando esta ênfase da lei adverte que a proteção legal deixa a descoberto o trabalhador do campo, ficando este praticamente exluido ảssa proteção que só favorece o trabalhador urbano. Lembra ainda que, se a atenção da 
polílica agíicolá se tivesse detido mais na importância das discussões a respeito do projeto-de-Lei sobre o Estatuto do Trabalhador Rurai, o debate ter-se-ia alargaủo e seriam evit́a das as deficiências em que iricidiu a lei 4.214, publicada no Diário Cficial de 18 de março de 1963.

TOSCANo (1976) anālisañ̉o a evolução e composí ção da população agrícola do Estado de são Paulo, no período 72-76, observa ser alta a taxa de participação ảos menores com menos de 15 anus, no trabalho agricola durante as tarefas estacionais, afirmando que, se o mesmo representa em média cerca de $20 \%$ da mão-de-obra agrícula, nos meses de maior trabalho essa taxa aumenta sensivelmente. Esta participação é mais solicitada nás épocas de culheitá, chiegando a se igualarem trabalho do menor e trávalho adulto.

A porcentagem de $20 \%$ ë bem maior do que a dos Estados Unidos em 1950.

ARAUJO MARTINS (1978) volta-se especificamente para a particípação do menor como força de trabalho no setor primário, apresentando na IV Reunião Nacional sobre Mão-de-Olsra Volante na Agricultura, realizada em Botucatu, Estado de São Paulo (1978), um estudo sowre o tema. Considera que a utilização do trabalho do menor na agricultura está relaciona da com os diferentes niveis de desenvolvimento das forças pro dutivas do meio rural. Analisa a questão em diferentes DIRAS 
do Estado de São Paulo e do Paraná.

O autor observa que a expansão capitalista efetuou-se rapidamente no Estado de São Paulo, em decorrência do desenvolvimento da economia cafeeira, dando origem a uma configuração espacial de áreas medernas onde se estabelecem culturas mais comercializadas e exploradas através de técnicas avançadas, ao lado de áreas tradicionais. O antagonismo entre essas áreas implica em diferentes formas de exploração do trabalho da população economicamente ativa. Nas áreas modernas, onde as relações sociais de produção se manifestam sob a forma de trabalho assalariado, o menor passa a competir no mercado de trabalho a fim de complementar a renda da familia. Em outras áreas, quando a família se constitui em unidade de produção, a mão-de-obra do menor aparece como um dos componen tes da exploração, uma vez que a força de trabalho é medida pelo nümero de pessoas em condições de manejar a enxada.

O estudo de ARAJO MARTINS (1978) analisa o problema no período 70/75. Segundo este estudo a utilização do trabalho do menor parece ser principalmente explorada nos pequenos e médios estabelecimentos, onde aparece como sendo mão-de-obra auxiliar e às vezes como reserva de força de trabalho. Em āreas onde a tecnologia apresenta progressos o menor surge como volante. Nas Divisões Regionais de Ribeirão Preto, Campinas e Bauru, onde a capitalização é mais intensa, decresce a utilização do trabalho do menor. Parecem justifi- 
car tal diminuição:

- a intensa e crescente mecanização das lavouras;

- o aumento das médias e grandes propriedades em detrimento das pequenas;

- o crescente aumento do trabalho adulto assalariado, com a diminuição do trabalho familiar.

Em outras DIRAS, como as do oeste Paulista e as de Marília, Sorocaba, são Paulo e Vale do Paraíba, conside ra o autor que a expansão capitalista se efetua em processo ora acelerado, ora mais moroso, resultando em maior utilização do trabalho do menor. Aumentou em números absolutos a utilização desse trabalho nas micro-regiões de Apiaí, Paranapiacaba e Campos de Itapetininga. Abrangendo, num leque muito grande, todas as DIRAS de São Paulo e Paraná, esse estudo deve ser considerado como uma abertura à discussão. Ele não se propõe uma análise exaustiva. Carecendo, também, de dados mais completos, a amplitude da área escolhida prejudicou sua profundidade.

Afirma ERAUJO MARTINS $(1978$ - 254) que "o aumento do emprego do menor tornou-se lugar comum no meio rural frente à crescente necessidade da familia de recrutar todos os braços disponíveis, de maneira a complementar os baixos rendimentos percebidos". No Brasil, em 1970, subia a 
2.900.330 o nümero de menores ocupados na agricultura. Em 1975 os dados consitários acusavam 4.481 .500 trabalhadores me nores.

O autor observa, em suas conclusões, que o trạ balho do menor, assim como o trabalho feminino na agricultura, são considerados como meios mais lucrativos para os empre gadores. Tanto mais que, embora o Estatuto da Terra prescreva para o menor um salário inferior ao do adulto, dada a menor jornada e a natureza mais leve dos serviços, na prática este salário é ainda inferior ao do trabalho feminino que, por sua vez, é inferior ao trabalho masculino na agricultura.

ANTUNIASSI (1981) denuncia a escassês de estudos sociológicos sobre o trabalho infanto-juvenil no meio rural, afirmando não existir significativa preocupação com o problema: limita-se a registrar a presença do menor nas tarefas agricolas. Lembra o trabalho de REBOUÇAS DE BRITO (1979) o qual registra a exploração da mão-de-obra de menores de 5 a 7 anos, entre pequenos produtores do Recôncavo Baiano. Cita CALDEIRA (1960) e observa que o fato do trabalho infantil assalariado aparecer em pequena quantidade pode ter levado os pesquisadores a não se interessarem pelo assunto.

ANTUNIASSI (1981-89) afirma que nas regiões predominantemente pecuaristas que também cultivam algodão e café, são os trabalhadores-mirim não assalariados que têm 
maior participação. Observou em sua pesquisa que, na região do Vale do Paraíba (Região II), a participação da mão-de-obra mirim aparece associada a um maior percentual de mão-de-obra familiar. As pequenas propriedades utilizam o trabalho infan to-juvenil integrado no trabalho familiar em maior quantidade. Nas DIRAs de Sorocaba e São Paulo, o trabalho infanto-juvenil representa cerca de $20 \%$ do total da força de trabalho nas pro priedades de até 20 ha. Esta observação de ANTUNIASSI confir ma aquela de KAUTSKY (1968) sobre o trabalho acessório do agricultor, quando adverte que tal trabalho resulta em maior utilização da mão-de-obra das mulheres, crianças e dos avós, na lavoura da própria gleba.

4.2. Educação elou escolarização e trabalho rural do menor As considerações tecidas por KAUTSKY (1902) a respeito da relação trabalho-escolarização ocupam algumas páginas da obra intitulada "A Politica Agrária do Partido Socia lista". Nelas discute o problema nos meios urbano e rural. Comentando a exploraça da criança pelo trabalho agrícola assalariado, observa não ser necessário enviar crianças como em pregados assalariados à casa dos estranhos, no intúito de ocu pá-las eficazmente. Vedando-se o trabalho assalariado das criangas atē 14 anos, considera que, com maior razão, dever-se-ia vedá-lo na agricultura. Sugere mesmo ser preciso interditar, até uma idade mais avançada, o trabalho de crianças 
fora do lugar de domicilio, não obstante tal interdição, por si mesma, não resolver a questão do trabalho agrícola infantil, pois a criança encontra, na propriedade agrícola dos pais, ensejo suficiente para ser ocupada. Corre-se o risco de que os próprios pais aproveitem dos filhos até à estafa. Verifica o autor que a exploração dos filhos manifesta-se pelos esforços feitos no campo a fim de abreviar o tempo consagrado à escola.

KAUTSKY (1902 - 81) encarece a necessidade de se aperfeiçoar e desenvolver o ensino no campo, e isto no prö prio interesse da agricultura. Ao contrário da indústria que reduz à extrema simplicidade o trabalho do operário, a agricultura cada vez mais se complica, tornando seus instrumentos sempre mais delicados, e exigindo cada vez maior inteligência. Sugere o autor ser da maior importância que a instrução no meio rural seja largamente ministrada não só até os anos, mas que desperte o desejo de outra mais completa. Considerando que o agricultor exige o rendimento do trabalho infantil e crescencio tal exigência na medida em que escasseiam os trabalhadores agrícolas assalariados, sugere ser preciso que o ensino seja mais elevado, devendo comportar conhecimentos sobre as ciẽncias necessárias à exploração racional da agricultura tais como a quimica, a mecānica, a botānica, a zoologia e a geografia. 
Cabe aqui, novamente, referência a

CALDEIRA

(1960) o qual, segundo os objetivos de sua Pesquisa pretende: a. fornecer idéia a mais aproximada possível da escala em que o menor participa das atividades agrícolas , quer como membro da familia, quer como unidade autônoma de trabalho.

b. recolher informações que facilitem a avalia ção das possibilidades educacionais do menor no meio rural dos municípios investigados e dos possíveis fatores de interveniência negativa na sua escolarização.

Observa que o menor constitui habitualmente parte integrante da força de trabalho da familia e que sob di ferentes regimes de posse da terra é, em geral, contratada a atividade familiar. Além de se basear em dados do censo de 1950 sobre 140 municípios tipicamente rurais, nas diferentes regiões do País, o autor apresenta os resultados da pesquisa realizada entre familias rurais de Colatina, Estado do Espíri to Santo.

Em suas conclusões observa que o trabalho agrí cola do menor ocorre mais comumente, como tendência geral, nas regiões de economia escassamente desenvolvida, onde a agricul tura congrega a maior parte da população ativa.

Quanto à interferência do trabalho agrícola na escolaridade do menor, o autor conclui que trabalho e escola 
apresentam-se como elementos inconciliáveis. Ele não julga acertado fazer coincidirem as férias escolares com o tempo de maior atividade agricola, porque a medida lhe parece resultar em detrimento da integridade física e mental do menor. Este retornaria à atividade escolar em condições incompativeis com uma aprendizagem normal.

A conclusão fundamental do autor vincula o pro blema do menor na agricultura aos problemas da familia. Para ele, qualquer melhoria em relação ao trabalho e escolaridade do menor está condicionada às mudanças nas situações que obri gam muitos pais a utilizarem o trabalho dos filhos menores com prejuizo da escolaridade, para suplementar o orçamento doméstico. No exame da situação em Colatina também aborda a ques tão do despreparo de professoras pouco estimuladas pelo baixo nivel de remuneração.

O estudo de CALDEIRA (1960) levantou problemas que podem e devem ser reexaminados à luz das mudanças ocorridas na agricultura nos últimos 20 anos. Entre tais mudanças parece oportuno lembrar o processo de produção capitalista que se vai acelerando na agricultura brasileira.

WANDERLEY $(1979$ - 17) afirma: "O carater capitalista na agricultura brasileira parece ser hoje aceito pelos estudiosos da questão e o debate feudalismo-capitalismo perdeu seu conteúdo polêmico. A tendência dominante se orien 
ta no sentido de admitir o pressuposto da dominação do capital na agricultura nacional e de compreender as formas concre tas de sua reprodução, considerando que, em determinadas circunstâncias, ela cria e reproduz relações de produção diferen tes da relação definidora do próprio capital".

SILVA (1978) examinando o conceito de indústria e industrialização, vê a expansão cafeeira ligada à industrialização, considerando uma e outra como dois estágios de transição capitalista no Brasil.

GRAZIANO DA SILVA $(1978$ - 237) reconhece uma agricultura capitalista no Brasil quando afirma: "Pode-se dizer que a estrutura de distribuição da propriedade da terra enquanto produto de um determinado padrão de desenvolvimento capitalista, que não só defende como subsidia a grande propriedade, influi no mercado de oferta de produtos agrícolas e na absorção de meios de produção de origem industrial. E esse mesmo padrão de desenvolvimento capitalista que faz com que a propriedade da terra condicione o acesso aos meios de produção de origem agrícola, na forma de reservas de valor. $\underline{A}$ lém do próprio valor da terra em si e das riquezas a ela natú ralmente associadas, eles se constituem num estoque de riqueza potencial que, num determinado momento, pode ser convertido em dinheiro pelos proprietários".

MALASSIS (1969) relaciona a educação rural com 
o desenvolvimento econômico global e com o sistema geral de educação, observando que o desenvolvimento agrícola não é autônomo. Para ele às etapas ou períodos de desenvolvimento global correspondem etapas de desenvolvimento agricola.

Analisando a questão da oportunidade da educação rural, coloca como problema fundamental a necessidade de se saber se a educação é causa mais do que consequência do desenvolvimento. Argumenta dizendo que a história do crescimento agrícola mostra que este não parece estar ligado necessariamente ao desenvolvimento de investimentos intelectuais na agricultura. Cita casos de desenvolvimento por extensão e por fatores naturais (recursos da terra), que nada têm a ver com o desenvolvimento intelectual. Aceita, porém, que a história econômica demonstre exemplos de crescimento agrícola li gados à educação rural, como nos casos da Dinamarca, Israel, Japão, etc.

Observa que a educação não representa no meio rural ou em qualquer outro apenas um investimento mas se cons titui em direito fundamental da pessoa humana, um meio de escapar à desigualdade social e às diferentes formas de dominação. Observa ainda que nos países onde o processo de industrialização começa a se desenvolver, ocorre a transferência da população agrícola para atividades não agrícolas, cabendo à escola o papel acelerador nessas transferências, em detrimento do setor agrícola, que perde sua mão-de-obra. Observa- 
-se aqui a contradição capitalista, denunciada também pelo au tor: de um lado o desenvolvimento da educação é necessário pa ra assegurar o desenvolvimento rural; de outro, esse desenvol vimento facilita o acesso a carreiras não agrícolas e pode acelerar o êxodo dos mais capazes e que melhor internalizem os conhecimentos oferecidos pela escola.

Para MALASSIS (1975), mais preocupado com o problema da educação rural do que com o trabalho do menor relacionado com a educação, não basta a revisão dos programas das escolas rurais, nem a localização das escolas de agricultura no meio rural. O desenvolvimento da educação deve ocorrer paralelamente a toda uma transformação estrutural da agri cultura. Ele compartilha do ponto de vista daqueles que vêem na modernização da vida rural a única solução e sugere a adoção de medidas radicais como a reforma agrária, a pesquisa agricola, programas de desenvolvimento das comunidades rurais, assistência técnica, utilização de mão-de-obra rural na cons trução de estradas, casas e escolas e outros programas que vi sem tornar a vida no meio rural ao mesmo tempo mais produtiva e mais atraente.

Este autor afirma existir relação entre níveis de educação e níveis de desenvolvimento dos setores da ativida de econômica. Também considera a modernização da agricultura como causa e conseq̣uência do desenvolvimento da educação. Pạ ra ele não se pode separar a formação do agricultor, do pro- 
cesso de melhoria da agricultura. Tal melhoria supõe alterações fundamentais no regime de propriedade, na dimensão das unidades produtivas, na comercialização dos produtos agríco las, organização do crédito rural, etc.

Para MALASSIS (1969) o sistema de educação deve ter em vista o conjunto da comunidade rural. Não pode haver promoção individual sem promoção coletiva. Para atender a tais exigências torna-se necessária uma ação coordenada de diferentes profissionais (especialistas em saūde, ensino primário, educação de adultos, economia doméstica, educação rural, cooperativismo, etc.), ao nivel da comunidade.

Percebe-se que o autor não está preocupado ape nas com o ensino primário ou o ensino de Primeiro Grau para menores e, sim, tem em vista programas de Desenvolvimento de Comunidade. Sugere também que os sisternas de educação devem adaptar-se aos diferentes estágios de desenvolvimento econômi CO, considerando os sistemas educacionais intransferíveis de um pais para outro.

MALASSIS (1975-30-31) adverte de modo incisi vo que as formas de educação dependem dos sistemas sócio-econômicos ou das formas de produção. "Nas sociedades progressistas, explica ele, em razão do rítmo de mudança e da crescente complexidade dos processos de produção, a educação : é institucionalizada e a escola torna-se o símbolo da sociedade 
em desenvolvimento. A escola tem por objeto principal a aqui sição de conhecimentos; ela não cobre o processo educativo na sua totalidade: a familia, o meio de vida e o meio social con tinuam a desempenhar um papel fundamental ... Sub-sistema da sociedade, a educação reflete, necessariamente os principais traços dessa sociedade... A escola desenvolve um papel de formação ideológica, relacionado com as ideologias dominantes, inspiradas pelas classes dominantes... Sob esta perspectiva, sem emprestar ao termo um sentido pejorativo, a educação é, por natureza, conservadora". Estas observações levam a relacionar Escola Rural e meio Rural com o meio urbano, com a formação acentuadamente urbana dos professores, com a função urbanizadora e a natureza conservadora da Escola. Observa o autor $(1975-40)$ que os sistemas educativos baseados em uma formação geralmente tradicional, produzem muitos "admi nistradores" de zonas rurais que se vangloriam de "nada conhe cer em relação à agricultura" tanto para se desculparem quanto, provavelmente, para se fazerem notar. Acrescenta, além disso, ( $p$ 41) que "a taxa de formação rural é fraca, porque o acesso das populações rurais à educação é fraco, havendo tendência, em relação às pessoas mais instruidas, de deixar a agricultura" .

PEREIRA (1971) considera a Escola Primária como grupo social diferenciado em sub-grupos. Professores e alunos de uma unidade escolar formariam estes sub-grupos, a 
que 0 autor chama de sub-grupos de ensino. Neles existem ele mentos comunicadores e elementos receptores. O sub-grupo de ensino desempenha dois tipos de funções: a explícita e a implícita. A primeira consiste na transmissão da herança sócio -cultural, através da leitura e escrita, dos cálculos e elementos das ciências físicas, higiene, história, preceitos e valores morais, civicos e artísticos.

Segundo PEREIRA (1971-180), o conteúdo da herança sócio-cultural faz parte do patrimônio cultural das camadas sócio-econônicas urbanas "não inferiores". Liga-se este patrimônio a um estilo de vida urbana. Por isto mesmo, o sub -grupo de ensino atua nas comunidades rurais como agência ou instrumento de desintegração do estilo de vida rural, no que constituiria sua função implícita.

o autor observa que a atividade urbanizadora da Escola, no conjunto da rede de Escolas Primárias, realiza a função implícita do sub-grupo de ensino.

Ao lado da Escola, outras Instituições Sociais desempenham também esta função implícita e, provavelmente,com a maior influência.

O exercício da atividade urbanizadora da Escola e de outras Instituições suscita forte tendência à urbanização. 
PEREIRA (1971 - 183) observa que as escolas primárias das zonas urbanas e rurais do Estado de São Paulo não apresentam diferenças pronunciadas quanto às característi cas do corpo docente e quanto ao conteúdo cultural-urbano do ensino. O Estado controla a formação profissional dos profes sores e a própria atividade docente, através da fixação de programas e de um conjunto de padrões. Este controle não é absoluto mas, nem por isto, deixa de representar uma grande força homogeneizadora no ensino.

MARTINS (1975) apresenta um estudo sociológico sobre a valorização da escola e do trabalho, no meio rural. Propõe-se analisar a questão, não ao nível da situação escolar, mas ao nivel da situação-social, entendendo por sujeito de tal situação não apenas, nem propositadamente, o aluno do curso primário (portanto o menor), mas ainda as pessoas para as quais a escolarização do menor é parte do próprio teor de vida.

A escolarização não foi o tema principal da pesquisa que alicerça o seu estudo. Esta dizia respeito às Condições Sociais do Desenvolvimento Agrário em São Paulo. A partir dela o autor utilizou-se de entrevistas feitas durante o trabalho, as quais serviram de material empirico, objeto de análise. 
o homem começa a trabalhar desde a infância, sendo a escola habitualmente pensada em sua relação com o trabalho agrícola. Vários dos casos relatados mencionam explicitamente as idades com as quais muitos agricultores ingressaram no processo de produção agrícola. Analisando a questão da Valorização da Es cola e do Trabalho no meio rural, MARTINS (1969-86) observa que $\circ$ periodo entre 8 e 10 anos representou para os entrevistados mais do que o periodo da escolarização: o início do tra balho produtivo.

O autor chega a algumas conclusões sobre a valorização da escola. Para ele, escolarização e trabalho, ocorrendo concomitantemente, constituem uma característica geral na experiência de vida daqueles que tiveram acesso à esco la, sem distinção de estratos sociais rurais: proprietários e não proprietários, pequenos e grandes proprietários, arrendatários e assalariados e semi-assalariados. Observa que este não é um acontecimento só do passado, mas aparece ainda hoje, constituindo um dado da experiência de vida das crianças atuais no meio rural. Muito embora se tenha alterado a situação (o que é possivel inferir das entrevistas que relata), di minuindo a presença do trabalho infantil no meio agricola, um dado se torna evidente: o trabalho aparece como um valor na interpretação dos diferentes grupos da sociedade agrária, e como valor é considerado em relação às diferentes etapas da vida, desde a infância até à velhice. O trabalho pode ter 
sido também uma necessidade para as populações de imigrantes estrangeiros, mas foi e continua a ser um valor social.

MARTINS $(1975$ - 88) apresenta a opinião expres sa por um agrōnomo, filho de imigrantes: "O pai deve exigir, nem que tenha meios, do filho o trabalho. A turma sai com co nhecimento perfeito da vida e dando valor às coisas. As míni mas coisas têm valor. Para os outros é mais fácil. As coisas conseguidas com dificuldade, com luta, são mais duradouras, têm mais valor. Forma uma personalidade útil. Ao passo que os que têm tudo fácil eles têm aquela personalidade de pendente, e dependem só do pai, de colegas. A luta pela vida encontra mais dificuldades quando pequeno. Depois que a gente se torna pessoa é que vai dar valor a essa formação".

Para esse autor, quando no meio rural a escola aparece como forma de ocupação do tempo da criança, é porque equivale, na verdade, ao trabalho. Aceita-se a escola porque se valoriza o trabalho.

Concorda-se aqui com MARTINS (1975 - 89) quando ele afirma que existe uma imposição do Estado em relação à escola no meio rural. Esta imposição se manifesta em relação a algumas explorações agrícolas no desajustamento entre o ciclo escolar e o ciclo do trabalho agrícola. Muito embora o Ministério da Educação e Cultura tenha permitido a adequação necessāria, esta permissão não tem sido aplicada na prática 
pois o período de férias permanece o mesmo, de um modo geral, em todo o País. A imposição do Estado manifesta-se, sobretudo, na obrigatoridade dos estudos de 10 grau, lei que, aliás, não é respeitada por grande maioria da população brasileira.

$$
\text { Nas entrevistas relatadas por MARTINS }
$$

observa-se, e ele acentua, que a escolarização para o homem rural não chega a ser definida claramente. Insistentemente afirmam os entrevistados:- "Só para a gente se defender". "O que hā de claro na escolarização, explica MARTINS (1975-92) è o tipo de esforço que ela reclama do sujeito e de sua familia, pois o que representa é medido exclusivamente em relação ao trabalho que, por ele, deixou de ser realizado". o "sentido da tarefa escolar entre os ruricolas, aparece estreitamente ligado ao trabalho. "Tirar tarefa" significa cumprir a jorna da de trabalho que um homem pode fazer em um dia. Outra observação refere-se à forma como o rurícola considera a escola rização à maneira de um ritual, o que parece justificado pelo fato de ter o autor encontrado pessoas que se "desalfabetisaram".

MARTINS observa que a escola também aparece vinculada à consciência do desaparecimento de um modo de exis tência, o colonato, sendo a escolaridade vista, como recurso para suportar a passagem de uma forma para nova modalidade de vida. 
A resistência frequente à escolarização, encon trada pelo autor no meio rural é por ele vista como resultan te da falta de integração da escola em um escuema de necessidades vitais. Essa integração só ocorre quando o sujeito tem por objetivo emigrar para a cidade, ou quando o agricultor se envolve em relações materialmente significativas com o meio urbano.

Conclui o autor que no meio rural, a escola é aceita e valorizada apenas como equivalente do trabalho agricola, penoso e habitual, o que leva a familia a manter o fi1ho, às vezes, por muitos anos na escola, aceitando seu baixo rendimento escolar como uma consequência de o mesmo não ter "cabeça para o estudo". As aspirações em relação à escola não vão além de consistir em assinar o nome, ler mais ou menos, etc. Quando, porém, o proprietário ou o trabalhador encontra-se fundamentalmente inserido na economia de mercado, a escola representa outras aspirações. Ainda que então se considere o trabalho escolar como equivalente ao trabalho pro dutivo, é diferente a concepção de cada atividade.

MARTINS (1969 - 98) observa que unicamente nos casos em que o trabalho se determina como abstrato e social, é que no meio rural se admite ser a escola un recurso útil pa ra desvendar as concepções da vida urbana, com seu cabedal de normas e de usos comerciais, e de conceitos sobre a proprieda de privada. O trabalho infantil integra-se, então, no projeto 
da familia, deliberado ou não, de acumular capital e de liber tar-se da venda da força de trabalho ao proprietário da terra, ou de simplesmente ampliar a acumulação. O trabalho esco lar, conquanto socialmente valorizado como trabalho, passa a ser entendido como adestramento que possibilita a apreensão de certas abstrações fundamentais da sociedade urbana, como: linguagem, normas, etc.

Para MARTINS (1975) a escola no meio rural encontra-se irremediavelmente comprometida com as concepcões e valores urbanos dominantes na sociedade capitalista. Sua efi cácia no meio rural depende do envolvimento da população do campo, através da mercadoria, em relações sociais com a socie dade em que está incluida. Dependendo de relações mediatizadas pela mercadoria, a escola rural contém, então, implicitamente, a negação do próprio meio. Esta negação, na análise do autor, ocorre ao nível das condições de relacionamento do homem com o produto do seu trabalho por meio do mercado.

Segundo QUEDA e SZMRECSÃNYI (1976) a educação escolar, bem como a assistência técnica instituidas e operantes no meio rural, encontram-se vinculadas tanto à estrutura de propriedade e de poder do subsistema social rural, como também às relações entre este e outros subsistemas sociais.

Os referidos autores consideram a educação escolar e a assistência técnica como instrumentos de política 
agrícola e econômica e como produtos institucionalizados do sistema econômico e político da sociedade brasileira. A função que preenchem em seu desempenho no contexto das mudanças sociais é encarada como um processo de integração econômica, politica e cultural do subsistema rural à sociedade inclusiva. A integração que se processa opera-se em ritmos diversos, segundo as diferentes regiões.

Conquanto à preocupação central do estudo que apresentam não esteja propriamente e só na escola rural os au tores procuram historiar a implantação do ensino rural no Bra sil. Este não parece ter sido muito cedo objeto da atenção dos poderes constituidos, em relação ao sistema educacional. Apenas as chamadas escolas isoladas, constituidas de uma só classe, com alunos de diferentes graus de aprendizagem, tendo à frente professores improvisados, serviam ao meio rural. As migrações internas do campo para as cidades teriam, então, es timulado uma ideologia reformista segundo a qual seria preciso tentar modificar as condições de vida no campo, visando de sestimular e reduzir a migração e aumentar a produtividade econômica do homem rural. A pretensão que se teria em vista, então, seria a fixação do homem ao campo, através da modernização da vida econômica e social do meio rural.

Segundo as considerações de QUEDA e SZMRECSANYI (1976), apesar da criação do Ministério da Educação e Saû de e do Plano Nacional de Educação, como também da criação de 
um Instituto Nacional de Estudos Pedagógicos e da institucionalização de um Fundo Nacional do Ensino Primário, mantinha-se em situação de inferioridade o sistema de educação no meio rural.

O processo de industrialização que se implanta va no País e, sobretudo em São Paulo, incrementava sempre mais o êxodo rural. A partir de 1946, o Ministério da Agricultura assumia a supervisão de uma rede nacional de escolas agricolas de nível médio e superior, e o Ministério da Educação passava a promover a expansão da rede de escolas primárias rurais, criando a Campanha de Educação de Adultos e a Campanha Nacional de Educação Rural, que funcionou de 1952 a 1962

No entender de QUEDA e de SZMRECSĀNYI (1976 225) uma causa importante da intensificação do êxodo rural pa rece ter sido o processo de modernização do setor agrícola. Esta modernização se vem realizando à margem do sistema de educação escolar, o qual continua com os mesmos e antigos pro blemas. Atẻ 1970, mais de 42\% da população rural com mais de 14 anos permanecia analfabeta.

A escassès de dados estatísticos impediu os au tores de se estenderem em sua análise. Trata-se, como ê possível concluir com eles, de uma área de estudos que se encontra praticamente a descoberto. O trabalho desses autores não 
pode ser considerado como uma pesçuisa exaustiva apesar da apresentação de dados censitários. A preocupação central situa-se ao nível de considerações a respeito da escola primária e do ensino técnico-agrícola de nível médio, mas não explora a relação trabalho agrícola-escolarização. As informações his tóricas situam datas e iniciativas consideradas fruto dos interesses do sistema dominante.

GRILO (1978) propôs-se, em sua tese de Mestrado, estudar as formas de inserção da Escola Rural no conjunto das formas de produção econômica do campo. Seu estudo foi realizado em um "bairro rural" do Município de passos (MG), onde a pequena propriedade e as relações de produção tipicamente familiares constituem predominância. Ateve-se, não à problemática do menor, mas a uma análise que procurou incorpo rar os elementos da educação no meio rural, visando compreender um dos diferentes modos de consolidação do capitalismo no Brasil. Fez cuidadosa análise da situação das escolas rurais em seu campo de pesquisa. Observou que $84,8 \%$ das famílias julgam que a criança deve estudar e trabalhar ao mesmo tempo. Quanto ao conteúdo cultural do ensino, sua pesquisa revela que este aparece sempre referido às palavras "leitura" e "escrita". 18\% dos entrevistados relacionaram escolarização com projetos de trabalho.

Em termos de expectativa profissional dos pais 
em relação aos filhos, o autor observou que 33\% dos entrevistados querem que o filho seja "doutor", incluindo sob esse ti tulo, o médico, o advogado, o engenheiro e o agrônomo. 12\% es peram que os filhos se tornem fazendeiros; apenas 9\% esperam que os filhos se tornem lavradores.

Analisando o problema das relações "escola-meio rural", GRILO (1978-110) observa: "A escola não se incompatibiliza formalmente com a produção e estrutura agrárias. Mas é verdade que, ... está habilitando o indivíduo para um universo econômico e social que contraria, implicitamente, o rural". Enfatisa que a parte mais significativa dos conteúdos e práticas educativas foge ao mundo rural com suas referências ao mundo urbano; referências como questões de trânsito, canalização de āgua, esgoto, usinas, relações sociais, po litticas, econômicas, etc. Para ele, os fatos sob análise reforçam a idéia de que a exterioridade da educação rural, com seu descompasso em relação ao meio, co-participa de politicas elaboradas apenas no interesse da sociedade envolvente. Para 33 dos seus entrevistados, a escola é "coisa da cidade"; para 57\% "não deve ser só da cidade" e para 10\% o fato é indife rente.

Analisando os curriculos e os programas de ensino o autor observa que uns e outros, nas diferentes discipli nas, revelam profunda discrepāncia com o meio rural, apresentando-se vazios e absolutamente desconexos em relação ao pū- 
blico que pretendem atingir, isto é, à população rural.

A pesquisa de campo levou-o a verificar que as práticas escolares compativeis com a produção não eram ministradas dentro da escola e, sim, através da familia, ou através de práticas educacionais extra-curriculares, entre as quais o extensionismo. Sua análise vai-se afunilando em tor no da ligação entre política educacional para o meio rural e manutenção ou reprodução de classes sociais que sirvam ao sis tema capitalista. A atuação da escola rural tem como consequência a formação de um exército de reserva industrial, funcionando como instrumento qualificador do trabalho-mercadoria, capaz de gerar mais valia, ampliada pela educação recebida, favorecendo-se assim o capital.

Em suas conclusōes GRILO (1978-163) considera que a escolarização, qualificando por um lado a futura força -de-trabalho industrial e, por outro, contrabalanceando, com práticas pedagógicas, o próprio movimento, bloqueia eventuais brechas à mobilidade social, enquanto mantém a força-de-traba lho atrelada à produção alimentar ou, em uns poucos casos, à reserva para assalariamentos capitalistas na própria agricultura.

Assim a escola rural não se desincumbiria apenas de uma reprodução do sistema capitalista. Na realidade por ele analisada e segundo a sua perspectiva, a escola é con 
siderada como instrumento político de controle do trabalho. Tal controle é exercido em bases expoliativas, transferindo seus próprios custos à comunidade agrária que implicitamente nega.

DEMARTINI (1981) começando sua análise com referências históricas lembra que a Institucionalização do Ensi no no Brasil nasceu com a própria história da colonização empreendida pós descobrimento e posse da terra pelos portugueses. Iniciou-se em 1549 com a vinda dos primeiros jesuitas que acompanharam a comitiva do governador geral Tomé de Souza. Estes implantaram na Colônia as primeiras escolas, montando, no correr de mais de duzentos anos, todo um sistema de ensino que veio a se transformar em 1759 quando, pelo decreto do Marquês de Pombal, os jesuitas foram expulsos de Portugal e de todos os seus dominios. Ao afastar os jesuitas do Império e das Colônias e ao assumir a responsabilidade do Ensino Público, Pombal pretendia não apenas renovar os métodos e pro cessos de ensino, mas laicizá-lo em seus objetivos e colocá-lo a serviço dos interesses civis e políticos.

O Anuärio do Ensino de 1936-1937 mostra que apenas no século Xx surgiram algumas escolas rurais no Estado de São Paulo. Estudando a questão da Educação da População Rural no Estado sob perspectiva histórico-sociológica, DEMARTINI observa que as iniciativas no sentido da fundação de escolas só atingiam as áreas urbanas. Afirma à página 16 que 
"não parecia haver qualquer interesse em criar escolas na zona rural, fossem estas públicas ou privadas". Este desinteresse seria motivado pela mentalidade existente, ligada ao po der dominante, escravocrata, do tempo do Império, desinteressado da educação popular, convencido de que o trabalho da terra, como a atividade industrial, caberiam aos ignorantes e incapazes. Alguns autores destacaram a indiferença da popula ção em relação às escolas, mesmo nas cidades ou vilas em que foram criadas. Essa indiferença, teria diminuido nas últimas décadas do regime monárquuico, condicionado pela prosperidade econômica da então Província, hoje Estado de são Paulo. Outro fator apontado como responsável pelo aumento do interesse da população, mesmo rural, em relação ao ensino, consistiria na intensa imigração européia observada no final do Império. o autor faz referências à situação escolar dos trabalhadores li vres no meio rural, concluindo que inexistiam escolas para os filhos de colonos mas havia interesse destes pelo estudo, não apenas em relação aos colonos imigrantes como também em relação à população nacional residente em bairros rurais. Sugere que a questão do ensino rural no Estado de são Paulo deveria ser encarada em função dos diferentes níveis sociais existentes desde o império: 1. o dos fazendeiros, possuidores de escravos, que a partir de 1850 e sobretudo depois de 1888 passa ram a ter "colonos", "camaradas" e "parceiros", no trabalho de suas fazendas; 2. o dos sitiontes independentes, cultivando a terra en regime de trabalho autônomo, com mão-çe-obra fami- 
liar; e 3. aqueles agricultores da camada inferior, sem terra e sem autonomia de trabalho. Reconhecendo a falta de dados para uma análise conforme estes níveis observa que, com relação ao nível social dos fazendeiros, "ə. falta de escola no meio rural não os impedia de proporcionarem uma educação razoável aos filhos; quando não contratavam professores particu lares, (...) eram os filhos enviados para colégios e escolas superiores." Com base em documentos (cartas de una educadora alemã que viveu na zona rural do Estado de São Paulo de 1881 a 1883) afirma que muitas professoras residiam junto às familias dos proprietários, nas fazendas de café.

Com relação ao ensino para os outros níveis so ciais afirma terem sido marginalizados, em relação à escolari zação, durante todo o Império. Baseada, em documentos, cita referências da professora Ina Von Binzer que, em suas cartas afirmava: "A lei da emancipação de 28 de setembro de 1871 determina entre outras coisas, aos senhores de escravos, que mandem ensinar a ler e a escrever a todas essas crianças. En todo o Império, porém, não existem talvez nem 10 casas onde esta imposição seja atendida. Nas fazendas sua execução é quase impossivel ..."

O autor não esgota a questão mas apresenta duas conclusões que parecem pertinentes: 19) que não se pocie generalizar para o meio rural a indiferença ou aversão pela escola, com base no baixo nivel de escolaridade reinante, uma vez 
que a escola era, até pouco, praticamente inexistente na zona rural; 29) que não se pode considerar como "antecipatórias" as medidas tomadas durante o Império em relação à educação no meio rural. Tais medidas limitaram-se, aliás, frequentemente, à aprovação de leis não cumpridas. Os exemplos obtidos, docu mentados e citados por DEMARTINI são disso contestação, pois indicam que o interesse da população pelo ensino parece anteceder a criação de escolas. Sua análise exploratória limitou -se ao período do Império.

FUKUI (1981-33) identifica decréscimo deste in teresse em épocas posteriores. Em seu estudo afirma que "a década de 70 foi marcada por uma estagnação da escolarização no país, associada a um aumento do trabalho infantil e às dis cussões em torno de questões do menor carente e trabalhador." Considera então que a escola estabelece fatores de seletivida de que dão origem aos. "excluidos" da mesma. Entre os fatores que influiriam nesta situação estariam as próprias leis sobre o Ensino e sobre o trabalho, que se defrontam em situação de incompatibilidade.

A Lei 5692/71, que estabelece a Reforma do Ensino de 19 e 20 graus, estende o ensino obrigatório e gratuito de 4 para 8 anos. A obrigatoriedade atinge a população de 7 a 15 anos. Em contraposição, o trabalho é permitido por lei aos maiores de 14 anos; mas a própria lei permite, com aprovação do Juiz, que esse limite de idade seja rebaixado pa- 
ra os 12 anos. Começando a frequentar a Escola aos 7 anos, o menor deveria nela permanecer até os 15. Chamado, porêm, ao trabalho aos 14 e mesmo aos 12 anos, com permissão da lei, dei xa a escola ou a frequenta sem rendimento escolar efetivo.

FUKUI (1981-40) observa que, em relação ao sis tema escolar, "tem-se o reconhecimento oficial da estagnação da taxa de escolaridade, aliada a uma diminuição das verbas destinadas à educação no País".

Merece atenção este fato. Estaria a diminuição das verbas condicionada a um suposto desinteresse pela Es cola? Ou o que parece desinteresse evidenciaria o ingresso prematuro do menor no sistema de produção agrícola?! 


\section{ORIENTACAOO TEORICA E HIPOTESES DA PESQUISA}

\subsection{Referencial Teórico}

A revisão da literatura apresentada possibilitou que fossem destacados os conceitos básicos a servirem de referencial teórico para a pesquisa. São eles: os conceitos de Unidades Produtivas Agrícolas, de Relações Sociais de Trabalho, de Relação "Campo-Cidade" e de Institucionalização e Organização do Ensino. Através do Quadro 1 pretende-se visua lizar suas relações com a realidade pesquisada.

No nivel empirico aparece em destaque a unidade de análise, isto é, o Menor, e os problemas que, em relação a este, interessam ao pesquisador - Trabalho agricola e Escolarização, em inter-relação. 
QUADRO 1. Esquema teórico

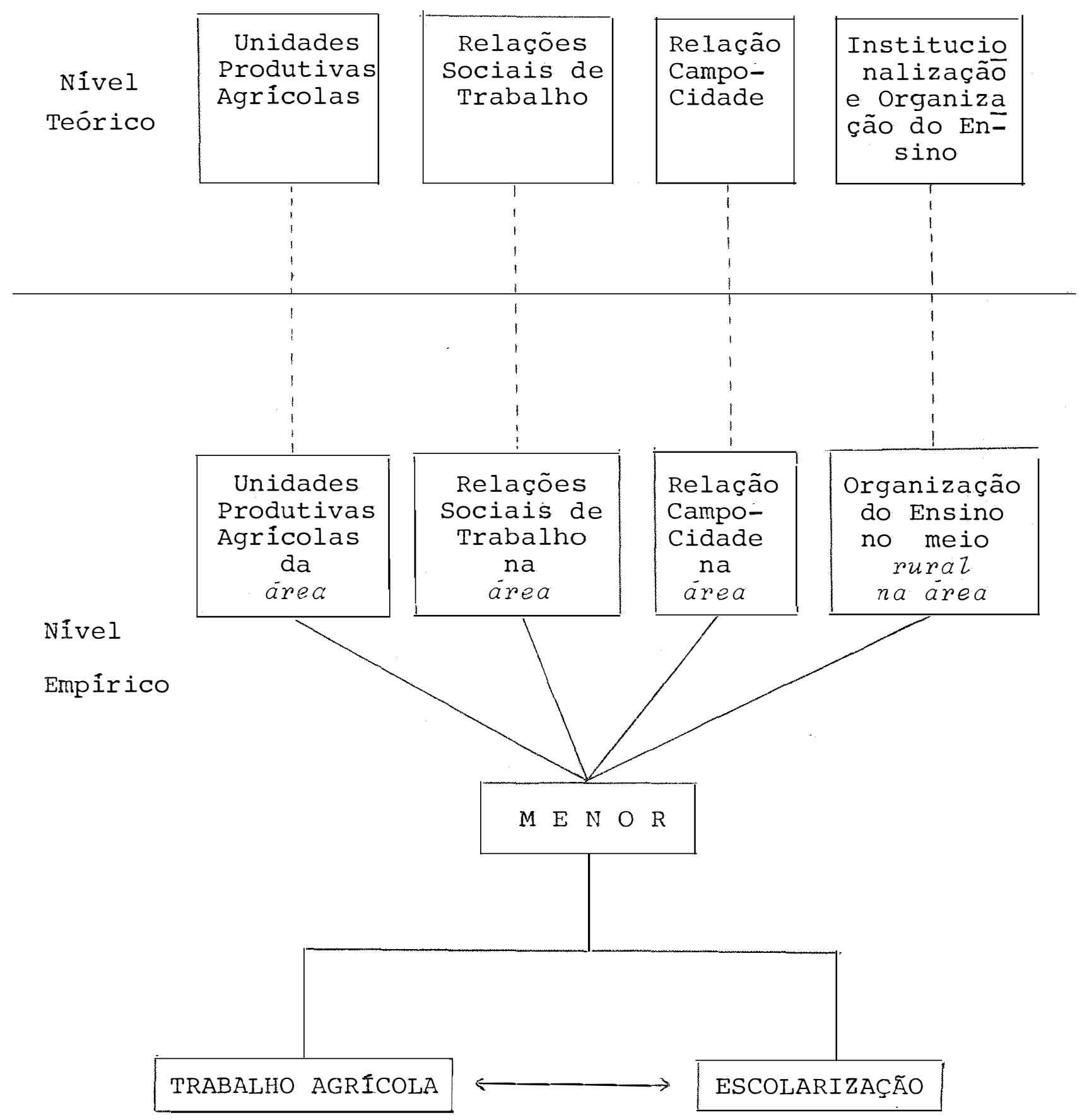


5.2. Explicitação dos Conceitos

\section{A. Unidades Produtivas Agrícolas (UPAs)}

Neste estudo foram considerados UPAs os chamados "Estabelecimentos". Estes, de acordo com a conceituação do IBGE (Censo Agropecuário de 1975) compreendem todo terreno de área contínua, independente do tamanho ou situação urbana ou rural, formado por uma ou mais parcelas confinantes, sujei tas a uma única administração, onde se processe uma exploração agropecuária. O IBGE considera como um único Estabelecimento as áreas que, ocupadas segundo diferentes condições legais (próprias, arrendadas, ou alugadas através de contrato de parcerial estejam sob a mesma administração. Considera co mo Estabelecimentos distintos as áreas confinantes pertencentes a um só proprietário, mas entregues a administrações diversas. De igual modo considera Estabelecimentos distintos as áreas exploradas em regime de parceria quando os responsáveis pela administração de cada área são os próprios parceiros.

Os Estabelecimentos ou UPAs incluidos na presente Pesquisa constam exclusivamente daqueles que apresentam como linha especial de exploração a cultura do café, ainda que mantenham outras 1 i has.

Na região da pesquisa os Estabelecimentos são 
chamados "fazendas", "sítios", ou "chácaras". Tal denominação não corresponde a uma classificação rigorosa.

Mesmo em uma região especificamente cafeiculto ra as UPAs apresentam caracteristicas diversificadas, o que, aliás, favoreceu o atendimento de alguns objetivos deste trabalho: analisar a associação entre os diferentes tipos de uni dades produtivas e a utilização do trabalho do menor en um liu nicipio cafeicultor; verificar as relações sociais de trabalho na cultura cafeeira de diferentes UPAs.

Existem vários critérios de classificação para distinguir as UPAs além daquele que enfoca suas principais produções: o tamanho da unidade, o volume da renda, etc.

MOLINA Filho (1977) considera tais critérios insuficientes e propõe uma classificação multidimensional, su gerindo uma tipologia construida a partir da realidade empíri ca: considera sua classificação aplicável a diferentes realidades rurais, sem desconhecer a possibilidade de discrepâncias, o que é comum a qualquer tipificação. Segundo ele, coe. xistem em todo o Brasil quatro tipos básicos de UPAs: a. as Unidades Produtivas Camponesas; b. a Empresa Familiar; c. a Empresa Capitalista; d. o latifúndio, assim caracterizados:

\section{O Latifúndio}

Este tipo de UPA supõe uma produção especializada, monocultura ou pecuária de corte, associada à produção 
para o consumo pelos parceiros. Usa pouca ou nenhuma tecnolo gia moderna e maquinária, atuando em um nivel de tecnologia pré-industrial. São propriedades senhoriais, multifamiliais, com grandes extensões de terra pouco aproveitadas. Não usam capital de exploração. Mantêm relações de produção não capitalistas e o proprietário não reside na área. Há grande dependência do mercado internacional e das cidades para consumo interno.

\section{A Empresa Capitalista}

Caracteriza-se pela superioridade do trabalho assalariado sobre outras relações de produção, inclusive a fa miliar. ivela a exploração é mecanizada, existe a utilização de insumos modernos, a UPA apresenta alta especialização, com uma ou poucas linhas de exploração destinadas ao mercado externo e interno, estando ausente ou inexpressiva a produção para o consumo. Na Empresa Capitalista há tendência a se reduzir a mão-de-obra residente, com exceção daquela altamente qualificada. A regra, quanto às dimensões, é a grande extensão de terra. Os juros do capital, a renda da terra e o lucro, determinam a tomada de decisões e a permanência da Empre sa no setor. As áreas exploráveis da unidade produtiva capitalista são totalmente utilizadas. Há grande uso do crédito bancário.

Os empresários capitalistas, geralmente, não residem na área da Empresa, embora ocorram muitos casos de 
ali residirem, principalmente quanco estão à testa da explora ção. Os empresários podem ser os proprietários ou, ainda, grandes arrendatários capitalistas, incorporando estes as mes mas caracteristicas dos empresários proprietários, com os quais se identificam.

\section{A Empresa Familiar}

A Empresa Familiar baseia-se essencialmente no trabalho da famỉlia, embora isto não implique na inexistência de mão-de-obra estranha. Se a atividade familiar se restrin ge às tarefas técnicas ou administrativas, a Empresa Familiar se aproxima da Empresa Capitalista, mudando seu caráter essen cial que é o trabalho familiar.

A Empresa Familiar faz uso de tecnologia indus trial con a utilização de maquinária e de técnicas agrícolas modernas. A área da unidade produtiva, entretanto, não é por demais extensa: varia em função das linhas de exploração da terra. E grande o uso do crédito bancário. Voltada para a produção de valores de troca, a dependência da Empresa Familiar em relação às cidades é um dado expressivo.

Os pequenos empresários familiares residem habitualmente na: área da UPA. Existem, porém, aqueles que resi dem nos bairros rurais ou na cidade próxima, estando frequentemente presentes à frente da exploração. Nas colheitas utilizam a mão-de-obra familiar além da mão-de-obra volante. 


\section{A Unidade Produtiva Camponesa}

E uma Unidade baseada exclusivamente no trabalho familiar, em pequenas extensões de terra com policultura, e voltada para o consumo da familia. Vende os excedentes não consumidos. Essa forma pura tende a se modificar com a crescente participação no mercado de produtos, para o que ten de a se concentrar em uma ou poucas linhas de exploração eminentemente voltadas para o mercado. Apesar disso a produção para o auto-consumo continua significativa na composição da renda bruta.

Sua tecnologia é pré-industrial. Neste tipo de UPA faz-se pouco ou nenhum uso do crédito institutional e do capital de exploração. O crédito usurário é a forma mais fre quente. Sua autonomia em relação às cidades e ao mercado de produtos e de insumos é muito grande na sua forma pura. Com sua inserção na economia de mercado tende a diminuir essa autonomia.

Os camponeses são residentes nas áreas de suas UPAs, ou próximos a elas.

Com frequência membros das familias camponesas trabalham em outras UPAs, em relações de produção polivalentes. 
B. Conceito de Relações Sociais de Trabalho

No sistema capitalista de produção, o trabalho aparece como mercadoria.

Em se tratando de formações sociais capitalistas, as relações sociais de trabalho supõem, de um lado, detentores dos meios de produção e compradores da força-de-trabalho e, de outro lado, trabalhadores desprovidos dos meios de produção, vendedores da sua força-de-trabalho. No meio ru ral são detentores dos meios de produção sobretudo os proprie tários, como também os arrendatários. Não se pode, porém, considerar de forma rígida, nesse meio, a divisão clássica en tre patrões e assalariados. No capitalismo agrícola, diferen temente do que ocorre no capitalismo industrial, as relações sociais de trabalho não se traduzem sob a forma exclusiva de assalariamento. Sem deixar de se constituirem em exploração da força-de-trabalho e de sua mais valia, outras formas de re lações sociais diferentemente configuradas, aparecem no meio rural: são as formas de parceria, arrendamento, empreita, tra balho volante (ou de boias frias). Conquanto diferentes, estas formas implicam na separação entre o produtor direto e o detentor dos meios de produção, portanto, o proprietário da terra. Esta, pertencendo aos proprietārios, é transformada ou entendida como capital fixo ou como mercadoria que pode ser vendida, alugada, emprestada ou legada. 
Importa esclarecer o que se entende neste estu do sobre os diferentes tipos de trabalhadores agricolase suas relações sociais de trabalho.

O I.B.G.E., ao conceituar e classificar os pro dutores, entende por parceiro a pessoa cue explora a terra de terceiros, em regime de parceria, mediante contrato verbal ou escrito, do qual resulta a obrigação de pagamento ao proprietário de um percentual da produção obtida (Censo agropecuário de 1970). No Censo de 1975 vêm definidos simplesmente como parceiros "as pessoas subordinadas à administração do Estabelecimento", percebendo "como remuneração parte da produção ob tida com seu trabalho (meia, terça, quarta, etc.), havendo a distinção entre estes e os parceiros autônomos, os quais são definidos como responsáveis pela administração do Estabelecimento. O Censo não fala em parceiros subordinados mas, na de finição de 75, acima apresentada, fala em pessoas subordinadas à administração, recebendo percentual sobre o produto do trabalho. O Manual do Entrevistador do Censo de 1980 denomi na parceiro empregado a "pessoa que exerce uma atividade econômica lagricultura, pecuảria, extração vegetal, caça, pesca ou garimpo), individualmente ou com auxilio de membro do domi cílio não remunerado, recebe uma parte da produção pelo traba tho e não possui autonomia em relação a quem the cede a parce ria". O mesmo Manual chama de "parceiro conta-pröpria" a pes soa que explora uma atividade econômica lagricultura, pecuá- 
ria, extração vegetal, caça, pesca ou garimpol, individualmen te ou com auxílio de membro não remunerado do domicillio, paga pela exploração com serviços e/ou parte da produção e possui autonomia em relação a quem the cede a parceria.

No presente estudo, sem preocupação rigorosa , são chamados de parceiros subordinados os que são entendidos pelo IBGE como parceiros empregados, e parceiros autónomos aqueles que gozam de autonomia em relação à administração do Estabelecimento agrícola.

Considerou-se como arrendatário o produtor que, sob contrato de arrendamento, verbal ou escrito, explora a terra pagando ao proprietário, em dinheiro ou em produto, no valor equivalente, o uso da terra. Este é também o conceito do IBGE no Censo Agropecuário de 1975.

- proprietário é entendido da mesma forma como o entende o Censo, isto é, como o dono da terra, o qual de senvolve ou não pessoalmente a exploração.

$$
\text { o assalariado tem, neste estudo, o mesmo senti }
$$

do do trabalhador assalariado, tal como o entende o sistema de produção capitalista. E preciso observar, porém, que o as salariado rural apresenta sub-categorias, aqui entendidas como assalarialos permanentes, e assalariados temporários. Nes te estudo foram adotadas estas duas sub-categorias para efeito da coleta de dados, não, porém, como critério rigoroso pa- 
ra a análise.

Os volantes, ou boias-frias, no universo da pesquisa e na região, eram pessoas que a si mesmas assim se denominavam quando, residindo ou não nas UPAs, trabalhavam por tarefa, por saco colhido ou por diária. Reservou-se para tais trabalhadores, indistintamente, as designações de boias-frias e diaristas.

Neste estudo também foi feita a distinção entre assalariado e empreiteiro, muito embora existam autores que preferem ver no empreiteiro um assalariado. Preferiu-se a distinção por se considerar que o empreiteiro pode apressar ou dilatar o tempo de sua produção, utilizando, inclusive, o trabalho dos filhos menores, enquanto que o assalariado é men salista (permanente ou temporário), sendo o seu salário avaliado e pago pelos dias ou meses de trabalho, não considerada a rapidês da produção. E preciso, porém, observar que um mes mo trabalhador ora trabalhava como empreiteiro, ora como diarista ou tarefeiro, na área da pesquisa. Para efeito da cole ta e análise de dados foram considerados empreiteiros os que, no ato da entrevista, se declararam como tais.

Resta considerar as relações sociais de produção em relação ao menor. No processo produtivo agrícola, a inserção do menor ocorre sob quatro formas possíveis de relacões de trabalho: a de assalariado permanente, a de assalaria 
do temporário, de volante e/ou tarefeiro, ou ainda integrado ao trabalho familiar, o que acontece comumente.

Os diferentes tipos de relação social do traba Iho existentes na agricultura determinam, com referência ao menor, o que aqui se entende por:

- Relaqões diretas, compreendidas como relação empregador-empregado, o que, no caso, se reduz à relação proprietário ou arrendatário e menor trabalhador assalariado.

- Relacões indiretas, aqui compreendidas como a utilização da atividade agrícola do menor através do trabaTho familiar.

E, finalmente, o trabalho do menor utilizado pela famizia do proprietário, arrendatário, parceiros ou outros.

\section{Conceito da Relação Campo-Cidade}

Este conceito é aqui entendido sob a ótica do mundo das mercadorias, que introduzem o homem rural na trama dos negö́cios e condicionam a sua nova visão de mundo. A mer cadoria produzida pelo trabalho industrial penetra no campo e cria necessidades antes inexistentes, valores de uso antes não desejados. Com esta nova visão o agricultor passa a considerar o trabalho agrícola como trabalho produtor de mercadorias 
Os sistemas dominantes de valores de troca empenham não somente a força-de-trabalho físico, mas também solicitam o dominio suficientemente seguro dos conceitos e valo res aceitos e correntes na sociedade inclusiva.

O homem rural passa a relacionar-se frequentemente com a cidade assimilando concepções e valores geradores de expetativas de vida diferentes da vida rural. A forma de relação vai desde a presença física mais habitual na cidade por motivos diversos, até ao contato intenso, no próprio meio rural, com valores urbanos, via meios de comunicação de massa introduzidos pela industria urbana, necessidades de finan ciamentos, vistorias da lavoura para fiscalização de empréstí mos, etc.

Estes contatos levam o agricultor a ver na lei tura uma necessidade indispensável para fazer negócios, transações financeiras, assinatura e compreensão de documentos. Passa ele a ver no raciocínio e no conhecimento da matemática (das contas, em sua fala simples), o meio para não ser engana do e para ganhar nas trocas. Em decorrência dessa nova visão impõe-se ao homem rural a necessidade de um conhecimento esclarecido sobre transações bancárias, cheques, ordens de paga mento, poupança, etc. Estimula-se nele o desejo de mobilidade geográfica, do êxodo rural, e da ascensão social, no senti do de trabalho mais rendoso e de melhor status. 
D. A Institucionalização e Organização do Ensi no

Para se conceituar a Institutionalização e a Organização do Ensino é necessário que se delimite aqui a extensão dos termos.

Institutionalização significa a sedimentação de qualquer comportamento social transformando-o em Instituição Social. Esta é um complexo integrado por idéias, padrões ou normas comportamentais, adotadas e sistematizadas por uma sociedade. As Instituições Sociais desenvolvem-se a partir de costumes nos quais estão radicadas. Normas ou leis são qualidades incidentais na vida das Instituições. A existência de uma Instituição Social supõe o consenso social. Daí a dificuldade de se transplantarem Instituições de uma para outra sociedade, culturalmente diferentes.

Há que se fazer distinção entre Instituições Sociais reguzativas e operativas. Interessam aos propósitos desta conceituação apenas as primeiras.

As Instituições regulativas, consideradas instıtuições primárias, têm funções de importância vital para a sociedade. Elas se propõem controlar determinados setores do comportamento dos indivíduos. São comumente entendidos como tais: a familia, a propriedade, o Estado, a escola e outras. 
se constituem em fatos sociais e, como tais, correspondem a maneiras de pensar e de agir que o individuo encontra pré-estabelecidas na sociedade. Sua transmissão se realiza através do processo da educação.

Os seruidores de DURKHEIM, sobretudo FAUCONNET (1874-1938) e MAUSS (1872-1950), procuraram explicar melhor o conceito, acentuando que as verdadeiras Instituições Sociais vivem e, portanto, transformam-se continuamente. Assim, elas existem entre todos os povos, apresentando formas diversas e, num mesmo povo, como nos demais, transformam-se no decurso da história.

Um outro aspecto a se destacar é o de que elas apresentam comumente um equipamento material organizado em torno de interesses socialmente reconhecidos. No Ensino este material se concretiza no sistema escolar.

Tem-se, pois, que a Escola, como Instituição Social regulativa, reveste-se de todas as caracteristicas des critas. O termo Escola sugere algo muito objetivo, configura do em uma unidade de ensino que compreende prédio, equipamentos, professor, alunos. A expressão Ensino parece mais adequada para significar a Instituição Social mais ampla, ocupada mais precisamente na organização do sistema de Instituições Locais de Ensino, as Escolas, destinadas a se empenharem na transmissão de conhecimentos e na formação ou na modifica- 
ção da conduta humana, direcionando-a através do adestramento, ou despertando o senso critico.

\subsection{Hipóteses da Pesquisa}

Explicado o referencial teórico que orientou o presente trabalho, cabe destacar as hipóteses que foram formu ladas, relacionadas aos conceitos apresentados.

Foram elaboradas sete hipóteses com vistas à orienţação da pesquisa. Estas foram designadas como H.1., H. 2., H.3., H.4., H.5., H.6. е H.7.

H.1. A utilização do trabalho do menor na cultura do café ocorre em todos os tipos de unidades produtivas.

H.2. O custo de mão-de-obra, como componente do custo da produção agrícola, leva à utilização habitual do trabalho do menor.

H.3. Relações sociais de trabalho estabelecidas sob a forma de arrendamento e parceria levam à maior utilização do trabalho do menor.

H.4. O trabalho do menor nas culturas cafeeiras é utilizado habitualmente em atividades agricolas consideradas leves $(*)$.

H.5. As atividades sazonais na cultura cafeeira levam à utili zação do trabalho do menor afetando a sua escolarização

(*) ver nota p. 4. 
de forma a provocar a evasão escolar temporária e até de finitiva.

H.6. A escolarização do menor será tanto mais habitual e perseverante quanto mais intensa for a relação campo-cidade no meio rural.

H.7. A escolarização no meio rural, influenciada pela organização do Ensino, direciona a população escolar e a comunidade rural à negação do próprio meio, pela falta de es tímulos aos valores e ao trabalho rural, motivando consciente ou inconscientemente expetativas urbanas. 


\section{METODOLOGIA}

6.1. Procedimentos gerais

No estudo da realidade empirica foram utilizados dados primários e secundários. Os dados secundários foram obtidos através de Relações Cadastrais do INCRA fornecidos pela agência local do Instituto Nacional da Coloni zação e Reforma Agrária, dos Relatórios Anuais/1980 da Prefe tura Municipal de Osvaldo Cruz, e os de 1980 da Delegacia de Ensino com sede no Município.

As informações sobre as DIRAs do Estado de São Paulo foram obtidas na Coordenadoria de Assistência Técnica Integral (CATI) e complementadas pela revisão de trabalhos pu blicados sobre o menor como mão-de-obra agrícola e como objeto-sujeito da educação.

Os dados primários foram obtidos através de questionários respondidos e preenchidos em entrevistas for- 
mais, realizadas pelo próprio pesquisador auxiliado por entre vistadores previamente treinados, entre os quais duas professoras de ensino médio, quatro professoras de ensino do primei ro grau e um estudante de oitava série, com experiência de ví da e de trabalho rural.

As entrevistas foram realizadas durante 0 mês de outubro de 1981, a fim de que pudessem ser analisadas as escolas rurais da região durante o ano letivo. Teria sido ideal, em relação ao ano agrícola do café, que a pesquisa pudesse ser levada a efeito durante todo o ano, considerando-se as fases da cultura cafeeira. De acordo com o calendário agrícola, esta supõe, além do preparo inicial do solo, a semea dura ou plantio (mais intenso de janeiro a março e de setembro a dezembro), a colheita (mais intensa de maio a julho, pro longando-se com menor intensidade até outubrol, e os tratos culturais (estendendo-se por todo o ano). A comercialização ocupa sobretudo os meses de julho a setembro inclusive.

\subsection{Definição da Amostra}

Foi feita a opção pela amostragem aleatória sim ples, tomando-se por critério de validade a regra de TOMPKIM (1967-55), segundo a qual "uma amostra de 50 observações é ge. ralmente o minimo. Se a população é menor do que 5.000 , cincoenta mais $2 \%$ é bom. Se mais de 5.000 , um por cento mais 
cincoenta deve ser usaảo".

Foram consideradas, para cálculo da amostra,as unidades produtivas agrícolas do Município, definidas como va riável contextual. Estas, segundo o cadastro do INCRA/1978, totalizavam 777 unidades. Feitos os cálculos a amostra limitou-se a um total de 65 UPAs, a serem aleatoriamente sorteadas, com reposição.

6.3. Critérios definidores para a coleta de Dados Primários

Foram adotados os seguintes critérios:

6.3.1. Forma de obtenção dos dados

Os dados foram coletados através de entrevistas, a partir de questionários. Estes foram utilizados como roteiro, sendo elaborados com base nas variáveis a serem analisadas, de acordo com o modelo conceitual estabelecido. Foi preparado um conjunto de cinco unidades distintas, compreen dendo:

a. Unidade 1. Unidades Produtivas Agricolas. As questões foram apresentadas ao responsável presente na ocasião da entrevista;

b. Unidade 2. Pais (ou responsáveis) 
c. Unidade 3. Menor Trabalhador, considerados como tais os Menores que executavam habitualmente tarefas agrícolas sob qualquer forma de relação social de trabalho.

d. Unidade 4. Escola. As questões foram respondidas: pelo próprio entrevistador (via observação) e pelo(s) professor(es).

e. Unidade 5. Menor Escolar. As questões foram respondidas por alunos entrevistados nas Escolas, aleatoriamente selecionados entre os discentes das diversas séries.

Os questionários foram testados na primeira quinzena de setembro de 1981, pelo próprio pesquisador, sendo depois reelaborados, mimeografados e preenchidos a partir das entrevistas, de acordo com os critérios a seguir apresentados.

6.3.2. Pessoas que deveriam ser entrevistadas

a. Responsáveis pelas UPAs sorteadas;

b. Pais ou Mães ou Responsáveis pelas famílias, aleatoriamente selecionadas, desde que desempenhassem trabalho agrícola na Unidade e que tivessem filhos em idade escolar, trabalhando ou não na agricultura;

c. Menores que desenvolvessem atividades agricolas; 
d. Responsáveis pelas Escolas Rurais situadas em locais próximos das UPAs e que atendessem à população rural dessas Unidades (constando entre tais responsáveis de 1 a 2 professores, quando a Escola contasse com mais de um profes sor);

e. Alunos das diferentes séries em cada Escola, aleatoriamente selecionados.

O número de pessoas a entrevistar não foi rigi damente pré-estabelecido em relação aos pais e Menores. Considerando-se a possivel diversidade das UPAs foi estabelecido variar entre 1 e 3 pessoas por Unidade, em relação aos Pais e entre 1 e 10 em relação aos Menores que executassem trabalhos agrícolas.

O número de alunos a entrevistar em cada Escola também não foi pré-estabelecido, considerando-se a possibi lidade de serem encontradas Escolas Isoladas e de Emergēncia com reduzido número de educandos e Escolas Agrupadas de bairros rurais, com maior população escolar.

Quanto ao número de pessoas responsáveis pelas UPAs foi estabelecido que seriam tantas quantas fossem as UPAs da amostra. 
6.4. Pessoas Entrevistadas

Foram entrevistados 65 responsäveis por UPAs, 78 Pais lentre os quais foram incluidos, nos casos pertinentes, os responsáveis pelas UPAs que, então, responderam a dois questionários) e 150 Menores trabalhadores, os quais desempenhavam habitualmente tarefas agrícolas, não considerados neste número os alunos entrevistados nas Escolas, entre os quais havia também os que desempenhavam trabalhos agrícolas. Em apenas 03 UPAs não foram entrevistados os menores que trabalhavam na lavoura em razão da extrema dificuldade de encontrá-los por estarem trabalhando em lugares muito distan tes.

Foram entrevistados 14 Professores de 12 EscoLas Rurais, duas das quais se caraterizavam como Escolas Agru padas de Bairros Rurais. Nas diferentes Escolas foram entrevistados 116 alunos, sendo: 09 da primeira série, 12 da segun da, 53 da terceira, 37 da quarta, 02 da quinta e 03 da sexta sẻrie.

Os dados foram codificados e tabulados por uma equipe coordenada pelo próprio pesquisador.

Foi escolhido o processo manual por ser pequena a amostra e significativo o número de questões abertas con tidas nos questionários. 


\subsection{Modelo Conceitual}

Conforme se disse na Introdução deste trabalho, para se definir a Metodologia da Pesquisa, foi elaborado o Mo delo Conceitual apresentado no Quadro 2, no qual se procura visualizar as relações existentes entre as variáveis.

QUADRO 2. V.C. (Unidades Produtivas Agricolas) $\rightarrow \mathrm{H} .1$.

x.1. Custo da mão-de-obra

x.2. Relações Sociais de Tra balho

x.3. Atividades Agricolas leves desempenhadas na entre-safra

x.4. Atividades Sazonais

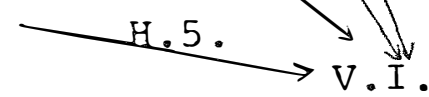
Trabalho $\rightarrow$ V.D. Escolaridade do Menor do Menor

x.5. Intensidade da Relação Campo-Ciidade

x.6. Organização do Ensino Rural 
6.6. Definição Nominal e Operacional das Variáveis

$$
\text { 6.6.1. Unidade de análise }
$$

Foi considerado como unidade de análise o menor do meio rural, situado na faixa etária de 07 a 18 anos in completos, conforme caracterização jurídica do menor.

A variação esperada (trabalha, não trabalha; estuda não estuda, nunca estudou, estudou e parou) foi medida através das respostas obtidas: a. junto aos responsáveis pelas UPAs da amostra; b. junto aos Pais ou responsáveis; c. junto aos Menores que executavam habitualmente tarefas agríco las; d. junto a Menores Escolares.

Visando a obtenção de dados para uma análise qualitativa, além da escala prevista para a classificação dos menores por faixa etária, e das questões fechadas sobre estudo e trabalho agrícola, foram colocadas questões abertas para medir a satisfação no trabalho e na escola, os anseios profís sionais, a internalização de conhecimentos apreendidos na Escola, o desejo de mudar ou não para a cidacie, questões que são apresentadas nos questionários em anexo.

Teve-se em vista: a. fornecer a idéia mais aproximada possivel sobre a situação do menor que, em idade es colar, quer como membro da familia, quer como força autônoma de trabalho, participa das tarefas agricolas; b. verificar a 
interferência dessa participação na escolarização e no proces so educativo do menor no meio rural.

Associando-se as variáveis estabelecidas procu rou-se apresentar, na medida do possivel: informações sobre as tarefas mais comumente realizadas pelo menor na cultura ca feeira; sobre as fáses da produção agrícola em que se aplica mais intensamente o seu trabalho; sobre as unidades produtivas que mais intensamente o utilizam e sobre sua remuneração, quando o contrato estabelece com o menor uma relação direta.

Deveriam ser considerados os menores situados na faixa etária que vai dos 07 aos 15 anos, considerando-se ser esta a faixa em que o menor deve frequentar a escola de 1. Grau. Foi preciso, porém, estendè-la dos 06 aos 18 anos, considerando-se as leis sobre a minoridade e o fato de terem sido encontrados menores de 06 e 07 anos trabalhando na lavou ra.

\subsubsection{Variävel contextual (V.C.) UPA}

Esta variável correspondeu às unidades de produção agrícola da região da Pesquisa. Nelas a utilização do trabalho do Menor poderia ou não ocorrer através da realização de diferentes tarefas agrícolas.

Foram consideradas para efeito da amostra somente as UPAS total ou parcialmente dedicadas à cafei- 
cultura, ainda quando o café não fosse o único produto explorado, desde que fosse colocado no mercado interno ou externo. As UPAs foram classificadas a partir do estudo da classificação proposta por MOLINA Filho (1977), procurando-se a sua ade quação à realidade empírica. Foi descartada a categoria dos latifundios por não aparecer na amostra. Em primeiro lugar, não foram encontradas UPAs cujas dimensões justificassem, por si, a tipificação segundo a categoria descartada. Em segundo lugar, observou-se que nas maiores UPAs encontradas, o nivel de tecnologia utilizada era significativo, o que a classifica ção de MOLINA Filho supóe inexistente na categoria. Por outro lado, não foram encontradas grandes extensões de terras não aproveitadas, considerando-se as extensões reservadas às florestas naturais e artificiais como medida de defesa ecológica. Não foram, também, encontradas propriedades senhoriais. Em relação à mão-de-obra, foram encontradas em 02 UPAs mais de 15 familias residentes trabalhando como parceiros subordinados, entretanto, considerando-se as outras caracteristicas, o fato não foi considerado relevante.

Foi necessário descartar também a categoria do camponês, não encontrada na ámostra.

Restavam ainda diferenças significativas que não facilitavam a categorização pura e simples das UPAs segun do as duas outras categorias básicas propostas por MOLINA Filho (1977), justificando-se por isto a construção de sub-ti- 
pos, a partir da própria posição do autor, o qual reconhece nos tipos que propõe, o que chama de "tipos básicos", aceitan do não ser plenamente satisfatória a classificação, dada a di versidade encontrada no meio rural. Criou-se, então, uma sub -tipologia que facilitasse a adequada alocação das UPAs da realidade empirica da Pesquisa.

Não foi possivel a aferição rigorosa entre o valor da porção comercializada da produção e o valor total, considerando-se que as informações obtidas careciam de precisão. O volume da produção foi, portanto, calculado pelo núme ro de pés de café da UPA.

Foram usados para a classificação também os ou tros indicadores apresentados por MOLINA Filho (1977-13): uso de maquinária e de insumos, diversidade das linhas de produção, tipo de administração, mão-de-obra assalariada.

Tomando-se como tipos-base a Empresa Capitalis ta e a Empresa Familiar, foi construida a seguinte sub-tipolo gia para a classificação das UPAs cafeicultoras da região:
a. Empresas Capitalistas;
b. Empresas Familiares;
c. Unidades Familiais Pré-Empresariais. 
Para que a classificação fosse viabilizada foram estabelecidos os seguintes indicadores:

a. Empresa Capitalista:

1. Administração diferenciada;

2. posse de outras UPAs no Município, fora dele ou fora do Estado;

3. contratação habitual de assalariados permanentes e/ou de boias-frias;

4. especialização cafeicultora voltada para o mercado, em quantidade bastante expressiva, avaliada pelo número de pés de café;

5. mecanização acentuada e uso sistemático de insumos;

6. utilização habitual do crédito bancário.

b. Empresa Famiziar

1. Engajamento da Familia na administração e no trabalho agrícola;

2. uso de insumos e maquinária sob tração animal ou motorizada;

3. especialização cafeaira (produção significa tiva, avaliada pelo número de pés de café);

4. poucas linhas de exploração intercalar para 
consumo;

5. utilização de boias-frias em ocasiões de maior trabalho e um ou dois assalariados permanentes;

6. utilização do crédito bancário.

c. Unidade Familial Eré-Empresarial

1. Engajamento da Familia no trabalho administrativo e nas atividades agricolas;

2. pouco uso de insumos, utilização de instrumentos primários (enxada) e, quando muito, arado com tração animal (apenas uma UPA);

3. cultura cafeeira para o mercado, com produção pouco significativa, avaliada pelo núme ro de pés de café;

4. algumas linhas de exploração para consumo;

5. rara e/ou inexistente utilização do crédito bancário.

6.6.3. Variável Dependente (V.D.)

- Escolarizacãa do Menor. Esta variável foi entendida enquanto relacionada com o processo de escolarização no meio rural, compreendendo a matrícula e frequência do Menor à Escola, e os estágios de estudos que consegue comple- 
tar. Sua mensuração foi realizada através de quatro fontes: a. informações da Delegacia de Ensino de Osvaldo Cruz; b. res postas dos Professores das Escolas que entraram na amostra; c. respostas dos Pais ou Responsáveis sobre a escolarização dos filhos; d. respostas dos menores (trabalhadores e/ou alunos) sobre a própria escolarização e frequência escolar.

Entendeu-se por matricula a inscrição do menor na Escola, a rogo dos Pais ou dos próprios Menores; sendo interrompidos definitivamente os estudos, procurou-se resposta que definisse o nível ou série em que o Menor havia deixado a Escola. A frequência foi aqui entendida como o comparecimento dos Menores às aulas diárias. Estas informações foram obtidas a partir das respostas dos Pais, dos Menores e dos Professores (no caso dos Menores Escolares).

\subsubsection{Variāvel Interveniente (V.I.)}

Trabalho do Menor na Agricultura Cafeeira. Re feriu-se esta variável à utilização do menor na realização de tarefas agrícolas: a. relacionades com a cultura do café; b. relacionadas com produtos intercalares cultivados em UPAs cafeicultoras, fossem ou não tais produtos destinados à comercialização; C. atividades agrícolas destinadas exclusivamente à manutenção da família, tais como: cuidados com a criação do méstica, atividade na horta familiar ou no quintal. 
6.6.5. Variāveis Independentes

As variäveis independentes foram designadas pe los simbolos $x .1 . \ldots .6 .6$.

x.1. Custo da mäo-de-obra. Esta variável foi destacada com o objetivo de se verificar a utilização do menor em atividades agrícolas, sob salārio ou sem ele, a fim de se testar a Hipōtese H.2.

o custo da mão-de-obra é entendido como a despesa feita pelo capital no pagamento do trabalhador. Esse cus to, na agricultura, pode aparecer sob a forma de salário lo que representa uma relação capitalista em seu sentido puro), como também sob a forma de contratos de parceria, empreita ou outros. Os contratos de empreita e de parceria, frequentemen te, implicam no trabalho familiar.

A mensuração desta variável esteve ligada às respostas relativas à utilização do trabalho de menores pela familia do proprietário e/ou arrendatário lque utilizando o trabalho dos filhos evitariam fazer gastos com assalariados, diminuindo o custo operacional da produção), bem como às respostas relativas à utilização do trabalho do menor como parte do trabalho familiar contratado sob reaime de parceria e/ou empreita. Se este fato ocorre, diminui também o custo opera- 
cional da mão-de-obra, aumentando as possibilidades de lucro do capitalista através da exploração da mais valia, que passa a estender-se ao trabalho não pago do menor. As respostas ou informações foram apresentadas: a. pelos responsáveis pelas UPAs; b. pelos Pais; c. pelos Menores Trabalhadores; d. pelos Alunos que trabalhavam na agricultura.

x.2. Relagões Sociais de Trabalho. Tendo-se como referencial as diversas categorias apresentadas neste trabalho, na parte referente à explicitação do conceito "Rela ções Sociais de Trabaiho", foram tomadas como indicadores para mensuração e análise da variável, além dos dados do INCRA: a. as respostas às perguntas feitas aos responsáveis pelas UPAs sobre a própria situação em relação à exploração da terra e em relação à própria terra e/ou ao seu proprietário; sobre as familias que trabalhavam na unidade, sobre os trabalha dores assalariados e outros que trabalhavam na unidade; b. respostas das familias através do Pai, Mãe ou Responsável c. das respostas dos menores que desenvolviam tarefas agricolas.

x.3. Atividades agrícolas leves desempenhadas na entre-safra. Foram assim entendidas atividades diversificadas próprias à agricultura tais como: a carpa ou capina 
(são realizadas quatro durante o ano), a esparramação, a arruação, o plantio de produtos intercalares e sua colheita, cuidados com a criação doméstica e adubação do solo.

Essas atividades dispensam o trabalho do adulto, e permitem atividades menos continuadas, ocupando menor tempo diário.

O pesquisador tinha em vista verificar quais as atividades desempenhadas pelos menores na região e observar o grau de influência de tais atividades na escolarização. Esta variável foi destacada no intuito de servir de referencial para se verificar a validade da hipótese H.4. Sua mensu ração foi feita através das respostas dos responsáveis pelas UPAs e das respostas dos menores, tanto daqueles que estavam afastados da Escola, como daqueles que a frequentavam e que realizavam tarefas agrícolas.

x.4. Atividades sazonais. Foram entendidas co mo tais as atividades da colheita que exigem aumento de mão-de-obra, sendo as do café facilmente possiveis de serem executadas por mão-de-obra infanto-juvenil.

Associando-se à hipótese H.5. esta variável foi destacada a fim de que se pudesse verificar se os menores eram ou não recrutados em maior número nos períodos das coIheitas e se êste recrutamento resultava efetivamente na eva- 
são escolar temporária ou definitiva. Tal resultado foi aferido a partir das respostas: 19) dos Menores Trabalhadores que ainda frequentavam ou que já haviam deixado a Escola; 2甲) dos Pais, com relação aos filhos que haviam deixado o estudo; 39) dos menores escolares que executavam tarefas agricolas e 49) dos professores, que informaram sobre o nivel de frequência escolar máximo e mínimo nos diferentes meses do ano.

\section{x.5. Intensidade da relasão Campo-Cidade. Esta} variável foi definida ao se esclarecer o conceito de relação Campo-cidade.

Nesta pesquisa procurou-se medir a intensidade dessa relação através de questões referentes: 19) à frequência e às razões das idas da familia à cidade; 2\%) à utilização dos meios de comunicação de massa no meio rural pelas fá milias dos agricultores (pais entrevistados) e 3o) às aspirações de mobilidade geográfica para o meio urbano.

Na mensuração da variável procurou o pesquisador aferir a Hipótese H.6. "A escolarização do menor será tanto mais habitual e perseverante quanto mais intensa for a relação campo-cidade no meio rural". Por isto foi necessário considerar ainda entre os indicadores, os dados relativos à escolaridade, que poderiam confirmar ou rejeitar a hipótese. 
x.6. Organizacão do Ensino Rural. Destacando -se esta variável o objetivo previsto consistia en se verificar como a organização do Ensino Rural se concretizava na área da pesquisa, como atendia às necessidades do meio e como influenciava na escolarização e no processo educativo do menor.

Sendo a organização do Ensino concebida como o resultado do exercício da função atribuida aos órgãos oficiais da administração geral, representantes da Instituição Social de Ensino na área, entendeu-se caber à Organização do Ensino Rural local: a distribuição de cargos nas Unidades Escolares, a determinaçaõ de programas, o atendimento às necessidades da população escolar.

Na mensuração da variável procurou-se verificar a validade da hipótese H.7. Tal mensuração foi realizada a partir de diferentes respostas:

a. informações da Delegacia de Ensino a respei to do nümero e localização das Escolas Rurais, das transferên cias de Professores, condições de lotação para o cargo, nưmero de alunos matriculados e Programas de Ensino;

b. respostas dos Professores em relação à pró pria formação profissional, aos programas de ensino, às influências da situação da Escola sobre a matrícula e frequência de alunos, etc.; 
c. respostas dos Pais em relação aos horários das aulas, tempo de férias, contato pessoal com a Escola e com os Professores, distāncia da Escola, etc.;

d. respostas dos alunos a respeito do conteúdo programático, dos conhecimentos que conseguiram internalizar, da importāncia que dão à Escola, das razões que os levam a va lorizar ou desvalorizar a Escola, do sentido valorativo por eles atribuido comparando-se trabalho agricola e trabalho escolar e, Einalmente, de suas aspirações em relação ao nível de estudos a que aspiram chegar;

e. respostas dos menores trabalhadores que dei xaram de estudar a respeito de suas aspirações e motivações para voltarem ou não à Escola e a respeito das razões pelas quais deixaram de estudar. 


\section{ANALISE DOS DADOS}

7.1. Breves considerações sobre a ärea da Pesquisa

Já foi observado por diversos autores que a agricultura de uma determinada região não obedece a rotinas, nem representa unicamente uma resposta às condições de solo e clima, fatores importantes, não, porém, os únicos.

o cenário agrícola tem raizes históricas; representa $\circ$ ajustamento entre diferentes atividades possiveis e as politicas agricolas, os processos de urbanização e de in dustrialização, a oferta e desenvolvimento do Capital e a demanda da terra, os incentivos ou subsidios governamentais e, ainda, às pressões da economia internacional.

E sabido que diversas têm sido as formas assumidas pela reprodução do Capital no setor agricola brasileiro. Este já se constituiu em principal "locus" de acumulação capi talista, através da prođução de matêria-prima para o mercado 
externo. Muito antes que a indústria penetrasse no País, já se produzia a acumulação capitalista através de formas variadas de produção agrícola.

- Estado de São Paulo manifesta a considerável diferenciação que, a partir da colônia e do Império, ocorreu na estrutura agrária da economia brasileira. Durante o século XIX O País, já independente e ainda sob a economia escram vista, inseriu-se no mercado mundial capitalista através da exportação do café, produto cultivado, sobretudo nos primórdios de sua exportação, no Planalto Paujista.

Quando a abolição transformou o mundo do traba Iho agrícola brasileiro, a introdução do colono imigrante nas novas áreas do café representou importante desenvolvimento do capitalismo agrário no Estado de são Paulo. Ao imigrante, na caminhada cafeeira para o oeste, foi possivel ter acesso à terra, graças aos seus rendimentos monetários e à disponibili dade de terras abandonadas pelo próprio café. Além de recebe rem salários em dinheiro, cabia aos colonos, frequentemente, o produto das culturas intercalares. Cabia-lhes também, frequentemente, o café colhido no período das plantações.

Nas zonas rurais, sob o regime do colonato, os armazens foram, aos poucos, substituidos por "vendas" de pequenos negociantes, o que contribuiu para libertar o colono da dependência do barracão, e para diminuir suas dívidas com 
o dono da terra.

Tais condições, aliadas à experiência que os imigrantes traziam de seus países de origem, favoreceram a acumulação de pequeno capittal monetário, logo investido em terras; com a aquisição de terras; constituiu-se também, ao ladio do latifündio, o regime de propriedades agrárias de requenos produtores mercantis.

Depois da grande crise de 1929, a partir da cé caảa de 30, o País incrementou o processo de industrialização. o chamado "Estado Novo" assumiu êste processo a partir das iniciativas de Volta Redonda, acompanhadas pelas leis trabaIhistas da ditadura populista de VARGAS.

Uma das consequências para o setor primário foi o desenvolvimento da exploração agrĩcola, voltada para o abastecimento urbano, e a consequente formação de um mercado interno, resultantes do crescimento das cidades.

No Estado de São Paulo produziu-se, então, uma considerável transformação na agricultura. Ao lado das grandes fazendas começaram a aparecer os pequenos "sitios". Os Ía zendeiros transformaram parte de suas terras em pastagens, con servando as encostas para a cafeicultura e cedendo aos sitios via arrendamento ou parceria, as várzeas próprias para o algo dão e a policultura, o que deu margem ao surgimento de uma ca mada crescente de pequenos produtores, arrendatários e parcei 
ros autônomos, voltados, em geral, para a produção destinada ao mercado interno.

Continuava a marcha para o oeste. Nos anos 50, constituiram-se fazendas e sitios dedicados à agricultura co mercial de abastecimento da região são Paulo-Rio, enquanto em outras zonas do Estado crescia a expansão da atividade agro-pecuária.

O histórico da região para a qual voltou-se o interesse da Pesquisa está ligado à marcha do café para o oes te do Estado.

Em 1921 Max Wirth, suiço que imigrou para

○ Brasil, adquiriu terras na região situada no oeste do Estado, entre 0 51: de latitude sul e o 220 de longitude (GR), e aí empreendeu a primeira derrubada da mata, visando a montagem de uma serraria e a possível organização de uma fazenda.

Nessa época Araçatuba era a cidade mais próxima, servida pela Estrada de Eerro Noroeste do Estado de São Pau10. Os moradores mais próximos à derrubada, de origem ale mã, residiam no patrimônio "Nova Pátria", mais tarde denomina da "Colônia Paulista". O imigrante foi, assim, entrando terra-a-dentro, rumo ao oeste. Um surto de maläria atingiu todos os homens de Max Wirth que, em 1922 retirou-se da região, deixando o latifúndio para ser valorizado. 
Em 1940, sediado na cidade de Oriente, Max Wirth organizou a colonização das terras compradas, então mu to valorizadas. A colonização processou-se sob a administração geral do Dr. Hans Schweiser e sob a direção técnica do en genheiro Dr. Hans Klotz. Ambos eram auxiliados pelos agrônomos Arno Keifer, Yutaka Abe, Ernesto Melan, Walter Schiller e mais tarde, em 1941, pelo engenheiro agrônomo Dr. Orlando Ber gamashi. Os próprios nomes ou sobrenomes revelam a origem estrangeira dos auxiliares de Max Wirth.

Aos trabalhos topográficos da região seguiu-se - loteamento, em pequenas propriedades. Estas passaram constituir as chamadas Chácaras Califórnia, NJegrinhra, Canaã e Lagoa.

A fertilidade das terras novas, em pouco tempo, atraiu o interesse de muitos para a Chácara Califórnia, onde, a 06 de junho de 1941, era fundada a Vila Califórnia, elevada no mesmo ano à categoria de distrito, com o nome de osvaldo Cruz. Em 1945 o novo distrito tornou-se Municipio, o qual passou logo a ser alvo do interesse de pequenos comerciantes e de pequenos produtores.

Atualmente encontram-se os pequenos produtores disseminados em todo o Município que apresenta uma área de $241 \mathrm{~km}^{2}$, ao norte da DIRA de Presidente Prudente, conformevem indicado no ANEXO 1 e que conserva suas características essen cialmente agricolas. 
A região, levemente ondulada. com a altidude média de 464 m acima do nivel do mar, dista da Capital, por ferrovia, $648 \mathrm{~km}$; por rodovia, em linha reta, $408 \mathrm{~km}$; via Bau ru, $570 \mathrm{~km}$ e via Assis, $550 \mathrm{~km}$. É banhada por inümeros côrregos e ribeirões que favorecem à agricultura. Destacam-se os ribeirões Negrinha, Valesburgo, Cateto e Drava; à pequena distância da divisa do Município, rios maiores, como o rio do Peixe e o Aguapeí, aos lados sul e norte, respectivamente, fa vorecem também ao clima, ao trabalho da terra e à pesca.

O clima e a topografia dão à zona rural as condições para uma exploração agrícola diversificada, facilitando a mecanização.

O Municipio tem como limites:

- ao norte, os Municípios de SALMORÃO E GUARA PES;

- ao sul o Município de SAGRES;

- do lado leste e do oeste, respectivamente, os Municípios de PARAPUÃ e de INÚBIA PAULISTA.

O Censo registra os seguintes dados populacionais: 
População

- Urbana

- Rural

Total
1970

$13.813 \mathrm{hab}$.

9.489

23.302
$1980 *$

17.633

8.505

26.138

Segundo o recadastramento do INCRA havia no Mu nicipio, em 1978, 777 unidades produtivas agricolas. As mais numerosas, medindo até 20 ha constituem, segundo o cadastramento, 61,2\% do total. Seguem-se-1hes, numa porcentagem de $18,1 \%$ as que contam entre 21 e 30 ha e, numa porcentagem de $11,4 \%$ as que medem de 31 até 50 ha. A partir de 51 ha decres ce abruptamente a proporção, passando a 4,1\% para as unidades de 51 a 90 ha; 1,4\% para as de 91 a 120 ha; 0,9\% para as de 121 até 150 ha e 1,1\% para as de 151 a 200 ha. Com mais de 200 ha contam-se apenas duas; a primeira com menos de 300 ha e a outra, pertencente ainda aos Max Wirth, com 2.749 ha, atualmente entregue à pecuária.

A área agrícola é ocupada sobretudo pela cafei cultura. Os dados mais atuais da Prefeitura Municipal / 1980 registram:

Cultura

- cafeicultura

- milho

- amendoim
Area

8.833 ha

2.000

700

*FIBGE: Sinopse Preliminar do Censo Demográfico. IX Recenseamento Social do Brasil. 1980. Rio de Janeiro, Vol I. To mo I. no 1. 1981. 
$-\operatorname{arroz}$

- feijão
400

300

Constituem-se em órgãos de Assistência Técnica à Agricultura, para a sub-região de Osvaldo Cruz: a Casa da Agricultura, a Cooperativa Agrária de Cafeicultores do sul de São Paulo, a Cooperativa Central Agrícola Sul Brasil e a Cooperativa Central Agrícola de são Paulo.

o Município é cortado, na direção leste-oeste, pela Estrada Estadual SP-294, com acesso até à sede. Estradas Municipais, não pavimentadas, servem também à região. FEPASA atravessa o Município na direção leste-oeste, passando pelo centro da sede.

7.2. Anālise dos dados e verificação das hipóteses

7.2.1. Variável Contextual - UPAs, em sua relação com a utilização do trabalho do Menor

A primeira aproximação que se impunha à análise era a classificação das UPAs da amostra, nas quais menores desempenhassem tarefas agrícolas. Tomando-se como referencial a tipificação estabelecida ao se definir operacionalmente a variável UPA, procurou-se fazer a análise de cada unidade, utilizando-se os indicadores estabelecidos para cada sub-tipo construido, a fim de se definir a distribuição das UPAs da amostra. 
Dados Gerais da Amostra

Os dados gerais revelaram que em $47,7 \%$ das UPAs eram habitualmente utilizados tratores, sendo utilizado o arado sob tração animal em 41,5\% das unidades. Em 87,7\% eram habitualmente utilizados insumos químicos, enquanto em 4,7\% este uso era raro. Não se obteve resposta sobre a utili zação de insumos no caso de apenas 02 UPAs; em apenas 01 unidade tal utilização limitava-se à época do plantio do café.

Apenas 07 unidades utilizavam Administradores. Estes orientavam e supervisionavam o trabalho, ficando a Admi nistração Econômico-Financeira por conta dos Proprietários,os quais se valiam habitualmente do trabalho técnico de contadores assalariados ou da própria família.

7,6\% das unidades utilizavam Agrônomo próprio, geralmente o Proprietário ou um parente relaciónado com o mes mo; em 6,0\% das unidades recorria-se eventualmente aos Agrôno mos das Cooperativas Agrícolas; aos da Casa da Agricultura re corriam 40,0\% das unidades. Em 46,4\% eram ouvidos os Agrônomos enviados pelo Banco, quando em vistorias preparatórias aos planos de financiamento e/ou inspecionando a aplicação dos empréstimos ou dos créditos concedidos.

Quando necessário, em 43,0\% das UPAs recorria-se a Veterinários da Casa da Agricultura; 3,0\% dos produtores declararam recorrer ao Veterinārio da Cooperativa e 6,0\% 
afirmaram recorrer a veterinário particular através de consul tas sob honorários.

Em relação, portanto, à tecnologia usada nas diferentes UPAs, verifica-se um nivel significativo, embora variāvel.

Em relação à extensão da terra por unidade, es ta não chegava a ultrapassar 300 ha. Através do Quadro 3 ë possivel perceber que a maioria das UPAs da amostra situavarn-se entre 02 e 60 ha.

QUADRO 3. Dimensões das Unidades Produtivas da Amostra - Muni cípio de Osvaldo Cruz - SP - 1981

\begin{tabular}{rcc} 
Ãrea em ha & UPAs & $\%$ \\
\hline $02-60$ & 55 & 84,7 \\
$61-150$ & 05 & 07,7 \\
$151-250$ & 02 & 03,0 \\
$251-310$ & 03 & 04,6 \\
\hline Totais & 65 & $100 \%$ \\
\hline
\end{tabular}

Os dados relativos ao produtor, quanto à responsabilidade dos declarantes apresentam um elevado número de proprietários, conforme se pode observar no guadro 4. 
QUADRO 4. Categoria dos Produtores por UPAs cafeicultoras Município de Osvaldo Cruz - SP - 1981

\begin{tabular}{lcccccc}
\hline $\begin{array}{c}\text { Area das } \\
\text { UPAs }\end{array}$ & $02-60$ & $61-150$ & $151-250$ & $251-310$ & Totais & $\%$ \\
Categoria & 36 & 03 & 01 & -- & 40 & 60,0 \\
\hline Proprietários & 36 & 02 & -- & 03 & 08 & 13,0 \\
Administradores & 03 & -- & -- & -- & 01 & 02,0 \\
Arrendatários & 01 & -- & 01 & -- & 16 & 25,0 \\
Parceiros & 15 & 05 & 02 & 03 & 65 & $100 \%$ \\
Totais & 55 & & & &
\end{tabular}

Aos dados do Quadro 4 parece oportuno relacionar os que se referem à tenência de outras UPAs. Entre os 40 proprietários da amostra, 67,5 을 possuiam outras terras no Municipio, fora dele ou fora do Estado, como é possivel obser var no Quadro 5.

QUADRO 5. Proprietários da Amostra possuidores de outras UPAs no Município, fora dele ou fora do Estado - Municipio de Osvaldo Cruz - SP - 1981

Area das UPAs em ha

Nūmero de Proprietários

\begin{tabular}{rrr}
\hline $02-60$ & 20 & 74,0 \\
$61-150$ & 04 & 14,8 \\
$151-250$ & 01 & 03,8 \\
$251-310$ & 02 & 07,4 \\
\hline Totais & 27 & $100 \%$ \\
\hline
\end{tabular}


Vale observar que esses proprietários detinham um total de 54 outras UPAs, entre as quais 57,4\% localizavam-se no Municipio de Osvaldo Cruz, 35,2\% estavam situadas em outros Municipios e 07,4\% localizavam-se fora do Estado de São Paulo.

\section{Classifieagäo das UPAs}

Os dados gerais aqui apresentados não são sufi cientes para se fazer a tipificação das UPAs. Sua apresentação teve por fim a visualização geral da amostra. A tipifica cão foi feita a partir da análise de cada unidade considerada como um todo, tomando-se por base os indicadores estabelecidos no capitulo 6 .

QUADRO 6. Unidades Produtivas Cafeicultoras - Municipio de Os valdo Cruz - SP - 1981.

Tipos de UPAS

NO

$\%$

Empresas Agrícolas Capitalistas

17

26,0

Empresas Agricolas Familiares

43

66,3

Unidades Familiais Pré-Empresariais

05

07,7

Totais

65

100 음 
Utiliageão do trabalho do Menor nas UPAs

O passo seguinte deveria ater-se ao problema da utilização da mão-de-obra infanto-juvenil nos diferentes tipos de UPAs. O Quadro 7 demonstra os resultados obtidos.

QUADRO 7. Utilização da mão-de-obra Infanto-Juvenil nas UPAs Cafeicultoras - Municinio de Osvaldo Cruz - SP - 1981

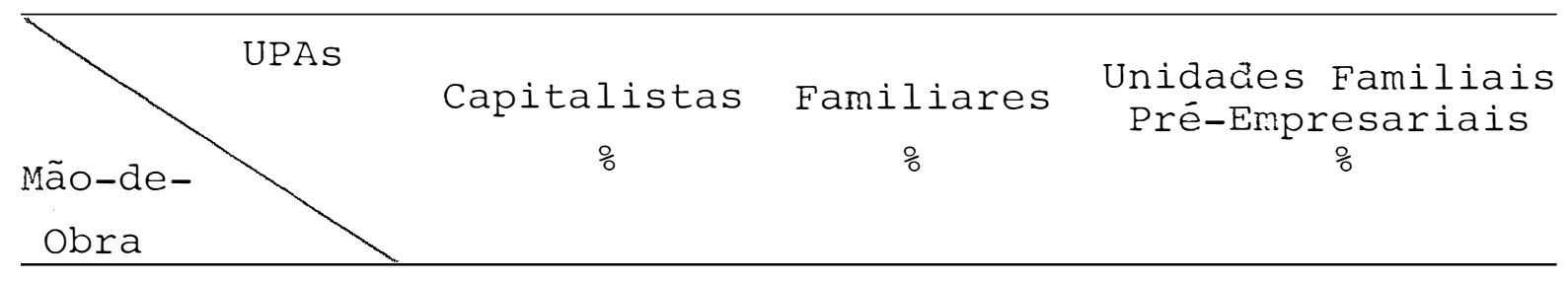

\begin{tabular}{lccc} 
Utilizada & 82,3 & 76,7 & 40,0 \\
Não utilizada & 17,7 & 23,3 & 60,0 \\
\hline Totais & $100 \%$ & $100 \%$ & $100 \%$
\end{tabular}

O Quadro 7 mostra a alta porcentagem de utilização da força-de-trabalho infanto-juvenil nas UPAs Capitaliṣ tas e Faniliares. Esta porcentagem decresce nas Unidades Familiais Pré-Empresariais, mas delas não está ausente, apresen tando 40,0\% de aproveitamento dessa força-de-trabalho. Os da dos confirmam a Hipótese H.1. assim definida: "A utilização do trabalho do Menor na cultura do café ocorre nos diferentes ti pos de Unidades Produtivas".

O tipo de trabalho realizado pela mão-de-obra infanto-juvenil nas diferentes UPAs foi outro dado considera- 
do. Para viabilizar a análise, o trabalho agrícola observado na realidade empírica foi classificado em três tipos básicos: trabalho familiar, trabalho assalariado, bóias-frias. Por Ira balho Familiar entende-se aqui a atividade agrícola realizada pela Familia do proprietário e aquela realizada sob as seguintes formas de relações sociais de trabalho: arrendatário, parceiro autônomo, parceiro subordinado, administrador e outros.

Estabelecidos os tipos para a classificação, f으 ram elaborados os Quadros 8,9 e 10, nos quais os dados de porcentagens deixam perceber a utilização do trabalho infanto -juvenil em relação ao trabalho adulto em cada tipo de UPA e en cada tipo de trabalho.

QUADRO 8. Mão-de-obra utilizada nas Empresas Agricolas Capitạ Zistas - Município de Osvaldo Cruz - SP - 1981

\begin{tabular}{|c|c|c|c|}
\hline Tipo de & $\underset{\%}{\text { Familiar }}$ & $\underset{\frac{9}{\circ}}{\text { Assalariado }}$ & $\begin{array}{c}\text { Bóais-Frias } \\
\frac{\circ}{0}\end{array}$ \\
\hline
\end{tabular}

\begin{tabular}{lccc} 
Adultos & 83,6 & 94,0 & 90,3 \\
Menores & 16,4 & 06,0 & 09,7 \\
\hline Totais & $100 \%$ & $100 \%$ & $100 \%$
\end{tabular}

Nas UPAs Capitalistas o trabalho do Menor é utilizado sobretudo através do trabalho familiar, numa porcen- 
tagem de $16,4 \%$

Nas Empresas Familiares a utilização do trabaIho do Menor em relação ao Trabalho Familiar eleva-se, alcançando 23,2\% (ver Quadro 9), o que representa um aumento de 06,8\% quando comparado com o mesmo dado da Empresa Capitalista. Em relação à utilização do Menor como Boia-Fria, sobe apenas $0,7 \%$, enquanto em relação ao Trabalho Assalariado, este desaparece. A constatação confirma as observações feitas des de KAUTSKY até os autores modernos, sobre a utilização acentuada do trabalho infanto-juvenil integrando o Familiar, em UPAs Familiares.

QUADRO 9. Mão-de-Obra utilizada nas Empresas familiares - Município de Osvaldo Cruz - SP - 1981

\begin{tabular}{lccc}
$\substack{\text { Mão-de- } \\
\text {-obra } \\
\text { trabalho }}$ & $\begin{array}{c}\text { Familiar } \\
\frac{\circ}{\circ}\end{array}$ & $\begin{array}{c}\text { Assalariado } \\
\%\end{array}$ & $\begin{array}{c}\text { Boias-Frias } \\
\%\end{array}$ \\
Mdultos & 76,8 & 100 & 89,6 \\
\hline Totais & 23,2 & $-0,4$ \\
\hline
\end{tabular}

Nas Unidades Familiais Pré-Empresariais o trabalho infanto-juvenil baixa em relação ao Trabalho Familiar $(18,7 \%)$, desaparecendo em relação às demais formas de traba- 
Iho, em que também desaparece o trabalho do adulto. Convém ob servar que as UPAs da categoria contavam, na região, com geni tores novos que tinham poucos filhos; observe-se, ainca, como nessas UPAs o trabalho era feito exclusivamente pela família.

QUADRO 10. Mão-de-Obra utilizada nas Unidades Familiais PrëEmpresariais - Municipio de Osvaldo Cruz - SP - 1981

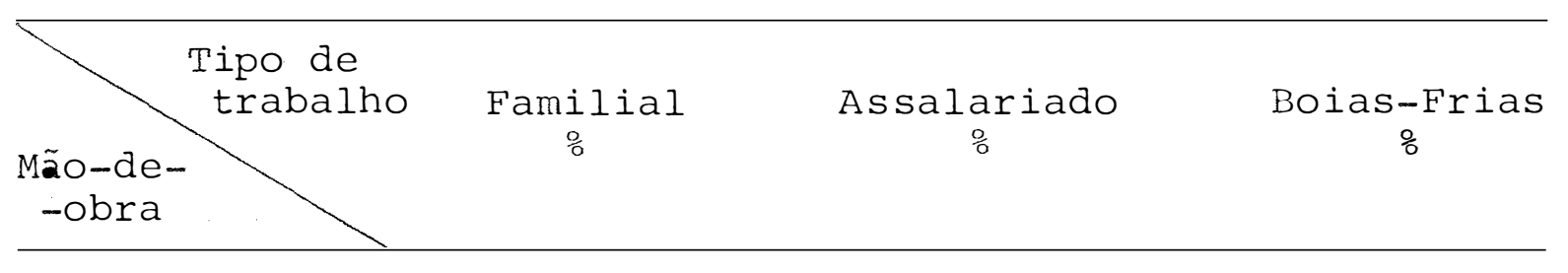

$\begin{array}{ll}\text { Adultos } & 81,3 \\ \text { Menores } & 18,7\end{array}$

Totais $100 \%$

Unindo-se os dados por Categorias de UPAs, sem se levar em consideração os tipos de trabalho (Familiar, Assa lariado e Boias-Frias) e possivel obter uma visão mais global quanto à utilização do trabalho do llenor, como o demonstra o Quadro 11 . 
QUADRO 11. Mão-de-Obra utilizada nos diferentes tipos de UPAs Cafeicultoras - Município de Osvaldo Cruz - SP 1981

\begin{tabular}{lccc}
\hline UPAs & Capitalistas & Familiares & $\begin{array}{c}\text { Unidades Faniliais } \\
\text { Pré-Empresariais }\end{array}$ \\
\hline Adultos & 87,7 & 80,0 & 81,3 \\
Menores & 12,3 & 20,0 & 18,7 \\
\hline Totais & $100 \%$ & $100 \%$ & $100 \%$ \\
\hline
\end{tabular}

Observe-se que nas UPAs classificadas como Empresas Capitalistas a porcentagem desce para 12,3\%, o que con firma a observação de CALDEIRA (1960) sobre a tendência à redução do emprego de menores na agricultura quando a região ou a sociedade apresentam estrutura industrial. E mais intenso este trabalho nas Empresas Familiares $(20,0 \%)$. A porcentagem alcançada neste tipo de UPA iguala-se à observada por TOSCANO (1976), referindo-se à população agrỉcola economicamente ativa do Estado de São Paulo. Decresce, porém, quando se compara o total da Não-de-obra utilizada na região, como o demonstra o Quadro 12. A porcentagern de mão-de-obra infanto-juvenil ê de 15,3\% na região da pesquisa. 
QUADRO 12. Mão-de-Obra utilizada nas UPAs Cafeicultoras - Município de Osvaldo Cruz - SP - 1981

Mão-de-Obra

응

\begin{tabular}{lr} 
Adultos & 84,6 \\
Menores & 15,3 \\
\hline Total & $100 \%$
\end{tabular}

E relevante observar que, nos diferentes tipos de unidades, a atividade agrícola dos nienores figura sobretudo integrada no Trabalho Familiar (ver Quadro 13), tipo de trabalho que oportuniza maior exploração de sua força-de-trabalho, como o demonstra a alta incidência de 73,5\%.

QUADRO 13. Utilização da Força-de-trabalho dos Menores nas UPAs Cafeicultoras, segundo a faixa etária dos Menores e segundo o tipo ce Trabalho - Município de Osvaldo Cruz - SP - 1981

Faixa

etária

\begin{tabular}{lcccccc}
$\begin{array}{l}\text { Rela- } \\
\text { Cöes de } \\
\text { Trabalho }\end{array}$ & $07-09$ & $10-12$ & $13-15$ & $16-17$ & Totais & \% \\
\hline Familiar & 04 & 36 & 57 & 25 & 122 & 73,5 \\
Assalariado & - & - & 02 & 01 & 003 & 01,8 \\
Boia-Fria & - & - & 39 & 02 & 41 & 24,7 \\
\hline Totais & 04 & 36 & 98 & 28 & 166 & $100 \%$ \\
\hline
\end{tabular}


Conforme se pode observar no Quadro $14,59,0 \%$ dos Menores que realizavam tarefas agricolas estavam na faixa etária dos 13 aos 15 anos. Somando-se as porcentagens referentes às faixas de $07 \ldots 15$ anos, tem-se un total de 83,1\% de Menores que, estando em idade escolar, eram ocupados habitualmente em tarefas agricolas. Na faixa dos 13-15 anos os Menores trabalhavam em todos os tipos de UPAs da amostra.

QUADRO 14. Menores que desempenhavam tarefas agrícolas nas di ferentes UPAs cafeicultoras, segundo a faixa etária - Municipio de Osvaldo Cruz - SP - 1981

\begin{tabular}{|c|c|c|c|c|c|}
\hline $\begin{array}{l}\text { Faixa } \\
\text { Etária }\end{array}$ & Capitalistas & Familiares & $\begin{array}{l}\text { Unidades } \\
\text { Familiais } \\
\text { Pré-Empre } \\
\text { sariais }\end{array}$ & Totais & 응 \\
\hline $07-09$ & - & 04 & -- & 04 & 02,4 \\
\hline $10-12$ & 11 & 25 & -- & 36 & 21,7 \\
\hline $13-15$ & 53 & 42 & 03 & 98 & 59,0 \\
\hline $16-17$ & 02 & 26 & -- & 28 & 16,8 \\
\hline Totais & 66 & 97 & 03 & 166 & $100 \%$ \\
\hline
\end{tabular}

Concluindo, é pertinente observar que, não apenas a força-de-trabalho do menor é utilizada em todos os tipos de UPAs como, também, essa utilização inicia-se com frequência relativa $(22,8 \%)$ entre 10 e 12 anos e mantém-se com 
incidência significativa $(56,0 \%)$ entre os 13 e os 15 anos, ocorrendo sobretudo através do trabalho familiar.

7.2.2. Variável x.1. "Custo da mão-de-obra nas UPAs da amostra e sua relação com o trabalho do Menor

Análise das Respostas obtidas junto aos Respon sáveis pelas UPAs

A atividade agricola de 122 Menores

constituia parte do trabalho familiar (verificar Quadro 13). Apenas 03 Menores $(01,8 \%)$ desenvolviam trabalho assalariado recebendo Cr\$8.500,00/mês: dois situados na faixa etária dos 13 aos 15 anos e 01 situado na faixa dos 16 aos 18 anos incom pletos; 24,6\% dos Menores recebiam como Boias-Frias, conseguindo a remuneração de $\operatorname{Cr} \$ 40,00$ a $\operatorname{Cr} \$ 130,00$ por saca, na colheita; apenas $02,6 \%$ dos Menores recebiam de $\operatorname{cr} \$ 283,00$ a Cr\$500,00 por dia de trabalho. Na época a remuneração do adulto era de $\operatorname{Cr} \$ 60,00$ a $\operatorname{Cr} \$ 130,00$ por saca e de $\operatorname{Cr} \$ 283,00$ a Cr $\$ 1.000,00$ por dia. Estes dados mostram como o trabalho do menor pode fazer baixar o custo operacional da produção, não apenas pela baixa remuneração, como pela sua integração no trabalho familiar.

Dados obtidos nas entrevistas com os Fais

pertinente a referência aos dados obtidos junto aos 78 Pais a respeito do salário dos filhos líenores. 
Estes coincidem em número com o total de Menores encontrados nas declarações dos Responsáveis pelas UPAs: 166.

Segundo as declarações dos Pais, apenas 02 Menores, ambos com 17 anos recebiam salários, sendo que um rece bia $\operatorname{cr} \$ 8.100,00$ e outro recebia $\operatorname{Cr} \$ 4.000,00$ por mês $(*)$.

$$
\text { Assim, entre estes } 166 \text { Menores, apenas 01,1융 }
$$
eram assalariados, sendo que o salário de um deles era reduzi do a menos de 50\% do salário mỉnimo regional da época, o que representa um exemplo da inobservância da lei salarial do trabalhador agrícola, visto que os dois menores tinham 17 anos, tendo ambos o direito ao salärio integral.

Através do Quadro 15 o pesquisador procura demonstrar a baixa remuneração da mão-de-obra na região. Trata -se de efetiva expropriação do trabalhador rural, tema que es capa aos objetivos do presente estudo, mas que fica evidente através dos resultados obtidos.

(*) Segundo os Responsáveis pelas UPAs, 03 Menores eram assalariados. A diferença de respostas é aparente. Os Pais entrevistados não coincidem com todos os Pais existentes nas UPAs. 
QUADRO 15. Nivel Salarial de Adultos e Henores em UPAs Cafeicultoras - Municipio de Osvaldo Cruz - SP - 1981

\begin{tabular}{|c|c|c|c|c|}
\hline \multirow{2}{*}{$\begin{array}{l}\text { Salá- } \\
\text { rio }(\operatorname{cr} \$)(*)\end{array}$} & \multicolumn{2}{|c|}{ Adultos } & \multicolumn{2}{|c|}{ Menores } \\
\hline & $\begin{array}{l}\text { Perma- } \\
\text { nentes }\end{array}$ & Temporários & $13-15$ & $16-17$ \\
\hline $1.000,00-4.000,00$ & 03 & - & $-\infty$ & $-\cdots$ \\
\hline $5.000,00-10.000,00$ & 02 & 52 & 02 & 01 \\
\hline $11.000,00-15.900,00$ & 40 & 02 & -- & $-\infty$ \\
\hline $16.000,00-20.900,00$ & 06 & $-\infty$ & -- & -- \\
\hline Totais & 51 & 54 & 02 & 01 \\
\hline
\end{tabular}

(*) Salário mínimo em 1981, no Estado de São Paulo: $\operatorname{cr} \$ 8.464,80$

Cabe lembrar que $73,5 \%$ dos Menores tinham seu trabalho incluido no trabalho familiar (ver @uadro 13), enquanto 24,7\% trabalhavam como Boias-Frias.. O trabalho fari liar reduz o custo operacional da produção, uma vez que não são imputados valores monetários ao uso desta mão-de-obra.

Importa ainda lembrar que 60,0\% dos Responsáveis pelas UPAs da amostra eram Proprietários (ver Quadro 4), utilizando, em sua maioria, o trabalho familiar. Quanto ao ünico arrendatário da amostra, usava o trabalho do filho menor, situado na faixa etária dos 13 aos 15 anos, como também contratava Boias-Frias, no tempo da safra, 03 menores ldois entre 13 e 15 anos e um entre 16 e 17). 
Concusöes da anärise da variáver x.1

Considerando-se a alta incidência do trabalho

familiar na região da pesquisa e levando-se em conta, como já foi dito, que apenas 03 Menores, segundo as declarações dos Responsāveis pelas UPAs e 02, segundo as declarações dos Pais, eram trabalhadores assalariados, e que apenas 24,6\% dos Meno res eram Boias-Frias, tem-se que a maioria dos Menores desen volviam atividades agrícolas sem qualquer remuneração, o que repercute expressivamente no custo-da-produção, mantido ao ní vel do mais baixo possivel, com a máxima exploração da força de trabalho familiar.

Os dados vêm confirmar a hipötese H.2.; "O cus to da mão-de-obra, como componente do custo da produção agrícola, leva à utilização habitual do trabalho do Menor". A con firmação da hipótese é reforçada pela utilização dessa mão-de -obra através do trabalho familiar.

7.2.3. Variäyel x.2. - Relações Sociais de Trabalho e sua relação com o Trabalho e a escolarização do menor

E sabido quanto são complexas e instáveis as Relações Sociais de Trabalho no meio Rural. Ao abordar a rea lidade empírica o pesquisador encontrou uma população a se de frontar com os problemas advindos da geada que, no inverno de 1981, atingiu grande parte dos cafezais em todo o oeste do Es 
tado de São Paulo. Entre as consequências estavam as mudanças nas Relações Sociais de Trabalho. Quando na pesquisa de campo os entrevistadores entraram em contato com os Pais, mui tos dentre estes haviam passado de parceiros subordinados a diaristas residentes. Percebia-se a preocupação e a insegu rança em que se encontravam os agricultores da região. O desejo de deixar a lavoura e procurar emprego na cidade era una constante, ainda que o receio do enfrentamento com tal possibilidade os tornasse indecisos.

Os Proprietários e Administradores tentavam oferecer soluções paliativas em relação às famỉilias dos lavradores, mostrando-se igualmente preocupados com a situação.Não refaziam os contratos de parceria, mas ofereciam trabalhos de emergência, permitindo a continuação da residência nas casas da fazenda ou sítio. Faziam os pagamentos por semana, de acordo com a tarefa contratada verbalmente. Eles mesmos mostravam-se indecisos entre o desejo de recompor os cafezais ou de abandonar a cafeicultura para se dedicarem à pecuária.

Embora interessado no acompanhamento da situaçao, nao foi possível ao pesquisador permanecer na região o tempo suficiente, nem a ela voltar, para chegar a um prognóstico seguro quanto às tendências que se esboçavam.

Entrevistas realizadas com os Pais

Tendo sido entrevistados 78 Pais ou responsä- 
veis por Menores, foram eles classificados de acordo com as Relações Sociais de Trabalho ou com a tenência da terra, una vez que, nas UPAs de menores dimensões o Pai entrevistado devia ser, quasi sempre, o Proprietário que explorava a terra.

O Quadro 16 permite observar çue os parceiros constituiram a porção mais significativa da amostra. o contrato de parceria variava na região entre 30 e 50,0\%. Mais co mum era o contrato de $40,0 \%$, com äireito ao plantio da lavoura intercalar: milho, feijão, amendoim. Nos quintais das residências, cuja terra não favorecia qualquer lavoura sem gran des e especiais cuidados, ficava a pequena criação doméstica (galinhas e un ou outro suino).

No Quadro 16 pode ser observada a alta incidên cia de diaristas residentes, antes parceiros subordinados. Sua redução a diaristas, consequência da geada, significa a tendência à crescente proletarização do homem rural. Este fa to revela o desamparo legal trabalhista do homem do campo.Não ficam os parceiros (autônomos ou subordinados), os arrendatários, os empreiteiros e outros, apenas à mercê das intempéries. Estas atingem tanto o agricultor espoliado quanto o proprietário rural capitalista. Nas ficam eles, também, à mercê da generosidade do patrão que os reduz a diaristas resi dentes, sem carteira assinada, sem salário fixo, sem amparo previdenciário. 
As Leis Trabalhistas que protegem o trabalhador urbano são esvaziadas em relação ao trabalhador rural,gra Gas ao trabalho volante, aos boias-frias, às empreitadas sem recolhimento em Institutos de Aposentadoria, aos contratos ver bais de parceria.

QUADRO 16. Categorias Laborais dos Pais ou Responsāveis por Menores que, em idade escolar, desempenhavam tarefas agrícolas - Municipio de Osvaldo Cruz - SP 1981

Categoria

Parceiros (autônomos e subordinados) 35 45,0

Diaristas Residentes

21 26,9

Proprietārios

09 11,5

Assalariados

07 09,0

Empreiteiros

05 06,4

Arrendatários 01 01,2 Totais 78 $100 \%$

Resta a questão dos arrendatários que aparece no enunciado da hipótese H.3. mas q̣ue, nos dados coletados, se constituem em porção inexpressiva: apenas 01 entre 78 Pais nas 65 UPAs era arrendatário. O dado parece significar mais uma vez a tendência crescente à proletarização do homen rural, 
pois o arrendatário pode constituir-se, até certo ponto, em um mini-capitalista ou, ao menos, com pretensões a tanto e, na região da pesquisa, sua presença é inexpressiva. Somando-se os parceiros aos diaristas residentes, empreiteiros e assalariados, obtém-se uma porcentagem igual a 87, 3\%.

O Quadro 17 mostra a situacáo relativa ao trabatho agricola dos menores pertencentes às familias entrevistadas. Foram colocados neste quadro os que estavam na faixa etária de 0-06 anos porque eles representam pessoas a sustentar e desenvolver sob a responsabilidade dos genitores. Ficam estes menores entregues aos cuidados de outros, tarabém me nores, durante a ausência dos pais que trabalham na lavoura. Os entrevistadores encontraram em várias casas crianças sozinhas.

Até aos 09 anos a participação no trabalho agrícola dos menores pertencentes às 78 familias, era pouco ex pressiva, A partir dos 10 anos o menor ingressava na faina diária, fazendo parte da população rural economicamente ativa, err proporções cada vez mais acentuadas como é possível ver no Quacto 17. 
QUADRO 17. Trabalho dos Menores pertencentes às Familias Entrevistadas - Municipio de Osvaldo Cruz - SP - 1981

\begin{tabular}{lcccccccc}
\hline $\begin{array}{c}\text { Faixa } \\
\text { etária }\end{array}$ & $0-06$ & $07-09$ & $10-12$ & $13-15$ & $16-17$ & Totais & \% \\
$\begin{array}{l}\text { Ativi } \\
\text { dade }\end{array}$ & 01 & 06 & 39 & 70 & 50 & 166 & 58,2 \\
\hline $\begin{array}{l}\text { Trabalham } \\
\text { Não trabalham }\end{array}$ & 47 & 37 & 27 & 03 & 05 & 119 & 41,8 \\
\hline Totais & 48 & 43 & 66 & 73 & 55 & 295 & $100 \%$ \\
\hline
\end{tabular}

A expressão, em termos de porcentagem, é eloquente como o demonstra o Quadro 18. Torna-se mais eloquente se forem somados os percentuais referentes às taxas de 10-15 anos, o que dará uma incidência de $65,7 \%$ de menores que nesta faixa etária desempenhavam tarefas agrícolas.

QUADRO 18. Desempenho de atividades agrícolas entre a população de menores das familias entrevistadas - Municí pio de Osvaldo Cruz - SP - 1981

\begin{tabular}{ccc}
\hline Faixa etária & Unidades & $\%$ \\
\hline $00-06$ & 01 & 00,6 \\
$07-09$ & 06 & 03,6 \\
$10-12$ & 39 & 23,5 \\
$13-15$ & 70 & 42,2 \\
$16-17$ & 50 & 30,1 \\
\hline Totais & 166 & $100 \%$ \\
\hline
\end{tabular}


A comparação entre estes dados e aqueles referentes às Relações Sociais de Trabalho dos Pais é apresentada no Quadro 19, o qual ressalta que a maioria dos menores rea liza trabalho não remunerado porque incluido no trabalho fami liar, através dos contratos de parceria, arrendamento, emprei ta, trabalho pago por diária familiar ou, ainda, através do trabalho da família proprietária ou arrendatária.

QUADRO 19. Relação entre a utilização do trabalho do menor e as Relações Sociais de Trabalho dos Pais - Municipio de Osvaldo Cruz - SP - 1981.

\begin{tabular}{|c|c|c|c|c|c|c|c|}
\hline $\begin{array}{r}\text { Idade dos } \\
\text { filhos }\end{array}$ & $0-06$ & $07-09$ & $10-12$ & $13-15$ & $16-17$ & Totais & \% \\
\hline Pais & & & & & & & \\
\hline Parceiros & 01 & 05 & 24 & 31 & 31 & 92 & 55,4 \\
\hline $\begin{array}{l}\text { Diaristas } \\
\text { Residentes }\end{array}$ & -- & 01 & 08 & 22 & 12 & 43 & 25,9 \\
\hline $\begin{array}{l}\text { Empreiteiros } \\
\text { Residentes }\end{array}$ & -- & -- & 03 & 04 & 02 & 09 & 05,4 \\
\hline Assalariados & -- & -- & 03 & 05 & 03 & 11 & 06,7 \\
\hline Proprietários & -- & -- & 01 & 07 & 02 & 10 & 06,0 \\
\hline Arrendatários & -- & -- & - & 01 & -- & 0.1 & 00,6 \\
\hline Totais & 01 & 06 & 39 & 70 & 50 & 166 & $100 \%$ \\
\hline
\end{tabular}


Dados resultantes das Entrevistas com os Meno res Trabathadores

Analisando as respostas dos 150 Menores trabalhadores entrevistados verificou o pesquisador que $86,6 \%$ desses menores têm suas atividades agrícolas integradas no traba Tho familiar. Estabelecida a comparação entre este dado e o dado anterior resultante das entrevistas com os pais, é encon trada a diferença de 13,4\%, facilmente explicável porque 166 menores trabalhadores pertenciam às familias e apenas 150 Menores foram entrevistados pessoalmente. Apesar da diferença isto revela o que já o revelára o dado anterior: a alta incidência do trabalho não remunerado do Menor.

A análise dos diferentes quadros e das inter-relações entre os dados leva a se inferir que as Relações Sociais de Trabalho dos Pais leva à inserção do Menor no trabalho agricola familiar. Esta exigência torna-se tanto maior quanto maior for a proletarização do trabalhador rural. A par tir desta conclusão é possível afirmar que a hipótese H.3. foi confirmada e as constatações da análise, levaram a complementá-la mais enfaticamente: "Relações Sociais de Trabalho na Produção Agrícola, estabelecidas sob as formas de arrendamento, parceria, empreitada ou por tarefa diária, forçam a utilização do trabalho do Menor que tende a aumentar na razão direta da maior espoliação do produtor ou do trabalhador rural". 
7.2.4. Variāvel x.3. Atividades agrícolas leves desempenhadas na entre-safra

Serviram de indicadores para a mensuração

e análise desta variável as respostas dos Responsáveis pelas UPAs (Questão 13 - Anexo II) e as respostas dos Menores sobre a própria atividade agrícola, conforme foi previsto na metodo logia deste trabalho.

Entrevistas com os Responsäveis pelas UPAs

Segundo afirmações dos Responsáveis pelas UPAs eram as seguintes as tarefas desempenhadas pelos Menores na cafeicultura: capina (em 69,2\% das UPAs); arruação e esparra ma (em 69,2\% das unidades); adubação do solo (em 61,5\%); adubação foliar (em 33,8\%); colheita $(70,7 \%)$; lavagem do café $(18,4 \%)$; secagem do café (em $32,3 \%$ ); beneficiamento lem 01 unidade produtiva). Realizavam ainda outras tarefas agrícolas, como: a. colheita de milho e amendoim - 01,8\%; b. capina pre parando a lavoura do milho e amendoim - 01,2\%; c. bater e cha coalhar amendoim - 01,8\%; d. Iimpeza e cuidados com a alimentação de suinos - 00,6\% .

Entrevistas com os 150 Menores Trabalhadores

As respostas obtidas revelam que 51,3\% desses Menores começaram a trabalhar entre 8 e 10 anos. Os que come çaram aos 11 e 12 anos alcançam a porcentagem de 20,6\%. Mas também, numa porcentagem de 06,0\%, houve entre esses Menores 
aqueles que começaram a trabalhar entre 05 e 06 anos. Suas atividades atuais consistiam tanto em pequenas tarefas (coIher paus, carregar leite, plantar verduras e legumes nas pequenas hortas das UPAs), como se estendiam às diversas atividades requeridas pela cafeicultura, pela lavoura intercalar ou pela pecuária doméstica: carpir, varrex ou rastelar, plantar, arruar, ajudar na esparramação, na colheita, na abanação e se cagem do café, no plantio e colheita do milho e do amendoim, no cuidado com as aves domésticas e com a criação doméstica dos suinos. Nenhum dos Menores entrevistados, declarou trabalhar na adubação química da lavoura ou dirigir tratores ,mas os declarantes nas UPAs afirmaram que eles também aplicavam a adubação foliar.

58\% desses Menores trabalhavam 8 horas por dia; 12 e 9,3\% trabalhavam, respectivamente, 04 e 03 horas diariamente. Conquanto em reduzida porcentagem, 03,3\% desses Menores trabalhavam em média, 10 horas por clia. Os que execu tavam atividade agrícola diariamente, por apenas 04 horas, nos dias feriados e durante as férias trabalhavam 08 horas. os de mais 29,4\% não declararam o nümero de horas durante as quais trabalhavam.

$86,6 \%$ desses Menores declararam gostar do trabalho agrícola, mas 65,3 dentre eles gostariam de fazer outro trabalho. Destes, 79,5\% gostariam de realizar trabalhos na cidade como bancários (office-boys), técnicos ein mecānica 
ou em eletricidade, secretários, desenhistas, comerciários,dọ mésticas, costureiras ou bordadeiras e operários.

Entrevistas com os alunos nas Escolas

116 Menores Escolares entrevistados nas Escolas Rurais também responderam a questões relativas ao traba1ho. 91,3\% declararam que trabalhavam; 59,4\% declararam trabalhar durante o ano todo, enquanto 30,2\% declararam trabalhar apenas durante alguns meses. Suas atividades variavam: 40,3\% trabalhavam mais em atividades domésticas para que os pais pudessem ir para a lavoura: Ievavam comida para os que trabalhavam na roça, lavavam roupas, cozinhavam, varriam os quintais, cortavam e carregavam lenha, puxavam água do poço, cuidavam dos irmãos mais pequeninos, preparavam espantalhos para colocar na plantação, davam água para a criação doméstica e tiravam leite.

59,4\% desenvolviam atividades agrícolas trabalhando com os pais e os irmãos na roça, ocupando-se na capina, no plantio do café, do amendoim, do milho e do arroz, colocando sacos de café no carreador para encher; colaborando na colheita e adubação do solo para o café e a lavoura intercalar; un dos Menores afirmou que ajudava o pai a passar o arado com tração animal, e a aplicar injeções no gado.

Reflexões conclusivas

Os dados confirmam a hipötese H.4.: "O traba- 
Iho do Menor nas culturas cafeeiras é utilizado habitualmente em atividades agrícolas consideradas leves". Realizando tare fas leves, cabiveis na entre-safra, os llenores são praticamen te ocupados na lavoura durante todo o ano, uma vez que também trabalham no tempo da colheita.

Cabem aqui algumas observações:

a. embora considerada leve, a capina exige grande esforço de trabalho. A sua prática habitual pode levar a consequências físicas indesejáveis em relação ao imaturo lexcessivo desenvolvimento muscular, desvios da coluna ver tebral, etc.). Considerando-se a fase de crescimento em que se encontra o menor, esta atividade não parece aconselhável;

b. a adubação do solo é um serviço exaustivo e insalubre, mesmo para adultos;

c. a adubação foliar, realizada com produtos químicos, praticada numa porcentagem de 33,8\% pelos lienores, segundo as declaraçōes dos Responsáveis pelas UPAs, constitui-se em atividade desaconselhável para menores, em razão dos perigos de envenenamento e/ou das doenças consequentes ao contato com tais produtos;

d. o trabalho agrícola de 8 horas diárias reaIizado por 58\% dos Menores trabalhadores parece ser excessivo e desaconselhável para pessoas em fase de crescimento físico e de uma desejável formação (intelectual, moral, cultura, so 
cial);

e. parece pertinente observar que a participação dos Menores nas atividades agrícolas ao lado dos pais e irmãos, desde que sejam respeitados um horário máximo de 03 a 04 horas diārias, o descanso dominical, a idade e o atendimen to às necessidades da formação e instrução, pode ser salutar à prōpria formação do menor, não apenas no sentido do treinamento agrícola, respeitadas as inclinações profissionais, como também no sentido da solidariedade no trabalho e da consolidação da coesão do grupo familiar.

\subsubsection{Variāvel x.4. - Atividades sazonais}

Com vistas à análise desta variável foram considerados os indicadores previstos: respostas dos Menores tra balhadores que ainda frequentavam ou que já haviam abandonado a Escola; respostas dos Pais sobre o estudo dos filhos e férias escolares; respostas dos alunos que executassem tarefas agricolas e dos professores das Escolas visitadas.

As atividades sazonais podem estar relacionadas com a possivel evasão escolar temporária e/ou definitiva.

Antes de se partir para a análise dos indicado res definidos parece oportuno apresentar os dados fornecidos pela Delegacia de Ensino e pelos Professores das Escolas Isoladas e de Emergência, em relação aos alunos matriculados 
(Quadro 20). Faltam as matriculas dos alunos das Escolas Agrupadas, cuja relação não constou daquela apresentada pela Delegacia de Ensino.

QUADRO 20. Matrículas nas Escolas Isoladas e de Emergência Municipio de Osvaldo Cruz - SP - 1981.

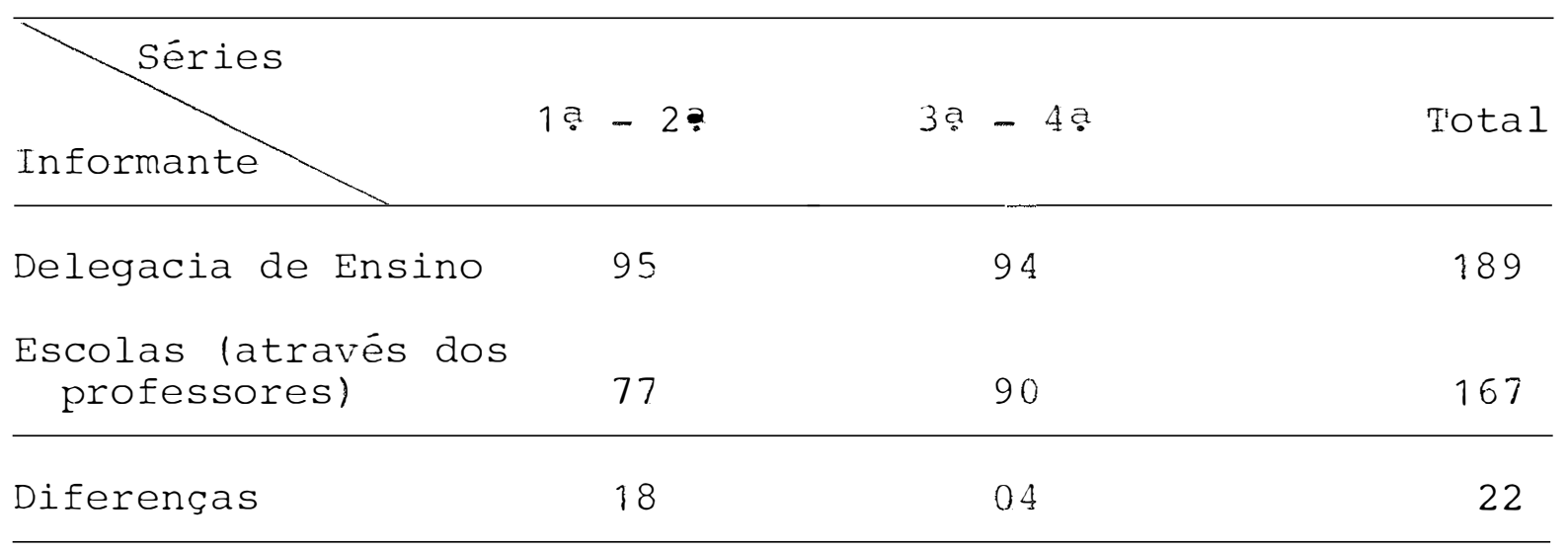

Identifica-se neste quadro uma diferença de 22 alunos. Os dados da Delegacia informam sobre a matrícula de todo o ano de 1981, até outubro; os dados das Escolas informam o nümero de alunos matriculados que permaneciam frequen tando as aulas.

A diferença observada representa uma porcentagem de 11,6\%. Estaria esse dado relacionado à evasão escolar resultante de atividades sazonais? A conclusão é prematura e exige dados mais seguros.

As respostas dos Menores Trabalhadores e dos alunos não forneceram dados esclarecedores. O receio de indu 
zir, levando o pesquisador a não colocar questões diretas sobre o trabalho sazonal, foi responsável pela falha nos dacos recolhidos junto aos Menores.

As respostas dos Pais, em relação aos meses de férias escolares, que possibilitariam obter dados sobre a sazonalidade, são lacônicas ou omissas e apresentam poucas justificativas. Apenas 08 Pais justificaram sua afirmativa com termos como: "Os meses de férias são bem escolhidos. Em janeiro e fevereiro os filhos podem ajudar na plantação e em $\underline{j u}$ lho, na colheita do café"; ou "Seria melhor que as férias fos sem em julho e agosto para que as crianças pudessem ajudar mais na colheita do café". 76,8\% das respostas limitam-se a afirmar: "Sim, os meses de férias foram bem escolhidos". Encontra-se uma negativa assim justificada: "As férias nunca são boas porque os filhos esquecem o que aprenderam". 21,9\% dos Pais não responderam. Assim, não havia possibilidades pa ra uma análise segura.

Recorrendo-se às respostas apresentadas pelos Professores, verificou-se que em apenas 8,3\% das escolas a frequência escolar descia ao nível de 86 e até $80 \%$ entre os meses de abril a junho, voltando ao nível de 97\% a partir de agosto. Algumas imprecisões no preenchimento dos dados sobre a frequência impedem uma análise mais rigorosa. 
nas Escolas de Emergência e nas Escolas Isoladas, como também dos matriculados nas Escolas Agrupadas dos dois bairros Rurais, as quais entraram na amostra, verificou-se que 59,4\% dos alunos desenvolviam habitual e diariamente atividades agrícolas. Esta porcentagem subia para 81,5\% no tempo da colheita do café.

Estes dados foram comparados com os Gráficos do Calendário Agrícola das Principais Culturas do Município. São aqui apresentados apenas os gráficos que se referem à cul tura do café, do milho e do amendoim, culturas mais significa tivas no Município $(*)$.

GRÁICO 1. Calendário Ảgrícoĩà ào Café.

\begin{tabular}{|l|c|c|c|c|c|c|c|c|c|c|c|c|}
\hline \multirow{2}{*}{$\begin{array}{l}\text { Fases da } \\
\text { cultura }\end{array}$} & \multicolumn{9}{|c|}{ Meses } \\
\cline { 2 - 15 } & Jan & Fev & Mar & Abr & Nlai & Jun & Jul & Ago & Set & Out & Nov & Dez \\
\hline $\begin{array}{l}\text { Preparo do } \\
\text { solo }\end{array}$ & & & & & & & & & & & & \\
\hline $\begin{array}{l}\text { Semeadura } \\
\text { ou plantio }\end{array}$ & $\bullet \bullet$ & $\bullet$ & $\bullet$ & & & & $\bullet$ & $\bullet$ & $\bullet \bullet$ & $\bullet \bullet$ & $\bullet \bullet$ & $\bullet$ \\
\hline $\begin{array}{l}\text { Tratos } \\
\text { culturais }\end{array}$ & $\bullet$ & $\bullet$ & $\bullet$ & $\bullet$ & $\bullet$ & $\bullet$ & $\bullet$ & $\bullet$ & $\bullet$ & $\bullet$ & $\bullet$ & $\bullet$ \\
\hline $\begin{array}{l}\text { Colheita } \\
\text { Comercia- } \\
\text { lização }\end{array}$ & & & & & $\bullet$ & $\bullet$ & $\bullet$ & $\bullet$ & $\bullet$ & $\bullet$ & & \\
\hline \begin{tabular}{l} 
Entre-safra \\
\hline
\end{tabular} & $\bullet$ & $\bullet$ & $\bullet$ & $\bullet$ & & & & & & & $\bullet$ & $\bullet$ \\
\hline
\end{tabular}

(*) fonte: Centro de Estudos Rurais da Fundação Getúlio Vargas. Calendário Agrícola Nacional. in: NEVES, E e outros. 1981. Fatores Sócio-Econômicos que afetam a Escolaridade na zona Rural do Estado de São Paulo. p. 53-54. 
GRÁFICO 2. Calenaārio Agrícola do Milho.

\begin{tabular}{|c|c|c|c|c|c|c|c|c|c|c|c|c|}
\hline \multirow{2}{*}{$\begin{array}{l}\text { Fases da } \\
\text { cultura }\end{array}$} & \multicolumn{12}{|c|}{ Meses } \\
\hline & Jan & Fev & Mar & $A b r$ & Mai & Jun & Jul & Ago & Set & Out & Nov & Dez \\
\hline $\begin{array}{c}\text { Preparo do } \\
\text { solo }\end{array}$ & & & & & & 0 & - & - & 0 & - & & \\
\hline $\begin{array}{l}\text { Semeadura } \\
\text { ou plantio }\end{array}$ & & & & & & & & 0 & 00 & - & - & $\bullet$ \\
\hline $\begin{array}{l}\text { Tratos } \\
\text { culturais }\end{array}$ & - & 0 & - & - & & & & & 0 & 0 & 0 & 0 \\
\hline Colheita & & - & 0 & 00 & 00 & 00 & 0 & & & & & \\
\hline $\begin{array}{l}\text { Comercia- } \\
\text { lização }\end{array}$ & 0 & - & - & - & 0 & 00 & - & - & 0 & ○ & 0 & - \\
\hline Entre-safra & - & & & & & & & $\circ$ & - & 00 & 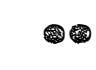 & $\infty$ \\
\hline
\end{tabular}

GRÁfICO 3. Calendârio Agrícola do Anendoim. 1ạ Safra (águas).

\begin{tabular}{|c|c|c|c|c|c|c|c|c|c|c|c|c|}
\hline \multirow{2}{*}{$\begin{array}{l}\text { Fases da } \\
\text { cultura }\end{array}$} & \multicolumn{12}{|c|}{ Meses } \\
\hline & Jan & $F^{\prime} e v$ & Mar & $A b r$ & Mai & Jun & Jul & Ago & Set & Out & Nov & Dez \\
\hline $\begin{array}{c}\text { Preparo do } \\
\text { solo }\end{array}$ & & & & & & & & - & - & & & \\
\hline $\begin{array}{l}\text { Semeadura } \\
\text { ou plantio }\end{array}$ & & & & & & & & & 00 & 00 & - & \\
\hline $\begin{array}{l}\text { Tratos } \\
\text { culturais }\end{array}$ & & & & & & & & & & ○ & - & 0 \\
\hline Colheita & 00 & 00 & - & & & & & & & & 0 & 0 \\
\hline $\begin{array}{c}\text { Comercia- } \\
\text { Iização }\end{array}$ & 20 & 00 & 00 & - & & & & & & & & 0 \\
\hline Entre-safra & & & & & & & & & & & & \\
\hline
\end{tabular}


GRÁfrco 4. Calendārio Agrícola do Amendoim. 2ạ safra (seca)

\begin{tabular}{|l|c|c|c|c|c|c|c|c|c|c|c|c|}
\hline \multirow{2}{*}{$\begin{array}{l}\text { Fases da } \\
\text { cultura }\end{array}$} & \multicolumn{9}{|c|}{ Meses } \\
\cline { 2 - 11 } & Jan & Fev & Mar & Abr & Mai & Jun & Jul & Ago & Set & Out & Nov & Dez \\
\hline $\begin{array}{l}\text { Preparo do } \\
\text { solo }\end{array}$ & $\bullet$ & & & & & & & & & & & 0 \\
\hline $\begin{array}{l}\text { Semeadura } \\
\text { ou plantio }\end{array}$ & $\bullet$ & $\bullet$ & - & & & & & & & & & \\
\hline $\begin{array}{l}\text { Tratos } \\
\text { Culturais }\end{array}$ & & $\bullet$ & $\bullet$ & $\bullet$ & & & & & & & & \\
\hline $\begin{array}{l}\text { Colheita } \\
\text { Comercia- } \\
\text { lização }\end{array}$ & & & & & $\bullet$ & $\bullet$ & $\bullet$ & & & & & \\
\hline Entre-safra & & & & & & & & & & & & \\
\hline
\end{tabular}

Considerando que a colheita do café é mais intensa nos períodos de maio-junho e julho, pode-se afirmar,com base sobretudo no aumento da porcentagem de alunos que trabalham na safra, que existe uma tendência à maior utilização do trabalho do menor em razão da colheita.

E possivel que os menores também sejam aproveitados nesse tempo para a colheita de milho, cujos meses de maior intensidade ocorrem de abril a junho. o mesmo pode ocorrer em relação à colheita da segunda safra do amendoim, que ocorre de maio a julho. Quanto à colheita desse produto, na safra que começa em novembro e se estende até março, com pico mais alto em janeiro e fevereiro, nela podem colaborar os menores em menor intensidade, aproveitando as férias maiores, 
levando-se em conta que o amendoim não é cultura muito expres siva no Município.

Conclusão da anälise da variävel $x .4$

Considerando-se a elevação da participação no trabalho agricola ao tempo da colheita, cuja percentagem alcança entre os alunos o nivel de $81,5 \%$ no período da safra do café, conforme já foi dito, pode-se afirnar que existe acentuada tendência no sentido de se utilizar a mão-de-obra infan to-juvenil nesse periodo. Como os dados sobre a frequência escolar, não foram precisos, parece prudente reconhecer que não são suficientes para a confirmação da Hipótese H.5: "As atividades sazonais na cultura cafeeira levan à utilização do trabalho do menor, afetando a sua escolarização de forra temporária e até definitiva". Foi possível, apenas, constatar que "as atividades sazonais na cultura cafeeira levam à utili zação do trabalho do menor, podendo comprometer sua frequên cia escolar".

7.2.6. Variāvel x.5. Intensidade da relação campo-cidade

Ao se passar à análise desta variável rarece oportuno lembrar que as UPAs visitadas estendiam-se por toảas as direções ào Municipio, ocupando a sede uma posição quasi central en relação ao todo, de moảo que, mesmo as mais distan tes UPAs estão em média a $30 \mathrm{~km}$ da seçe. Além disto, um sis- 
tema de ônibus liga a cidade a todos os pontos principais do Município e aos Municipios próximos, o que facilita a locono ção via estradas principais. Destas observações iniciais depreende-se que a população tem a possibilidade de frequentar habitualmente a cidade.

Ao ser iniciada a análise foram primeiramente estudadas as respostas referentes à frequência da população em seus contatos con o meio urbano, às razões de tais contatos, à utilização dos meios de comunicação de massa habitualmente usados e às expetativas de mudança de residência e de trabalho.

QUADRO 21. Frequência dos contatos da familia rural corn meio urbano - Municipio de Osvaldo Cruz - SP - 1981

\begin{tabular}{lcc} 
Frequência dos contatos & Familias & \% \\
\hline Uma vez por mēs & 42 & 53,9 \\
Uma vez por semana & 29 & 37,2 \\
Todos os dias & 01 & 01,3 \\
Quando necessārio & 02 & 02,5 \\
Respostas em branco & 03 & 03,8 \\
Nunca & 01 & 01,3 \\
\hline Totais & 78 & $100 \%$ \\
\hline
\end{tabular}


$37,2 \%$ das familias estabelecem contato semanal com a cidade, enquanto 53,9\% o fazem uma vez por mês. O Quadro 21 demonstra o que aqui vem afirmado, enquanto o Quadro 22 mostra as razões pelas quais são estabelecidos os contatos da familia rural com o meio urbano.

QUADRO 22. Justificativas apresentadas pelo agricultor para explicar seus contatos com o meio urbano - Ilunicipio de Osvaldo Cruz - SP - 1981.

Justificativas

Número

용

\begin{tabular}{lcc} 
Compras & 69 & 31,5 \\
Frequência à Igreja & 62 & 23,4 \\
Passeios & 46 & 21,0 \\
Visitas a amigos & 42 & 19,1 \\
\hline Totais & 219 & $100 \%$ \\
\hline
\end{tabular}

O nümero de justificativas apresentadas pelo agricultor, relativas à frequência dos contatos da família com o meio urbano, excede ao número dos entrevistados porque estes apresentaram de 2 a 3 justificativas.

Necessidades de manutenção (compras) e interes ses religiosos parecem ser as principais razões. Entretanto, interesses de ordem social (passeios e visitas a amigos) são também atendicios em percentagens significativas. Comparando- 
-se os dados dos Quadros 20 e 21 e levando-se em consideração que 69 Pais iam à cidacie para compras, enquanto 62 iam também para fins religiosos, é possivel afirmar, considerando-se ain do o número de Pais entrevistados que, entre $79,4 \%$ e $88,4 \%$ dentre eles vão à cidade motivados por interesses de manutenção e por interesses religiosos.

Os dados apresentados parecem demonstrar que a intensidade da relação campo-cidade se constitui en uma variā vel bastante significativa.

Os resultados obtidos nas entrevistas com os Pais em relação à utilização dos meios de comunicação de massa também trazem subsídios para a análise. Entre a população da amostra 29,5\% possuia Rádio ou 'I'V. Entretanto, 92,3\% das familias declararam acompanhar programas de Rádio, do que se infere que elas partilhavam dos aparelhos dos vizinhos e amigos. Os programas acompanhados, por ordem de preferēncia, eram os seguintes: noticiários, novelas, cantos sertanejos, mư sica popular, futebol, filmes. 60,2\% das familias assistiam às novelas da Rede Globo, enquanto 73,0\% ainda acompanhavam os noticiários da Rádio ou da TV em diferentes Estações. Ape nas 14,1\% das familias seguiam os programas agrários pela Rádio ou TV, enquanto 08,9\% declararam acompanhar todos os programas desde que alguém estivesse em casa. 05,1\% declararam que acompanhavam os programas de calouros, desenhos animados, shovs e outros. 
Menos expressiva entre a população rural da amostra era a influência da imprensa: os jornais eram lidos apenas numa porcentagem de 08,9\%. O dado parece ser em parte justificado pela proporção de analfabetos e/ou de semi-alfabe tizados. A partir das respostas dos 78 pais entrevistados fo ram obtidos, neste sentido, os dados seguintes: $42,5 \%$ clos Pais eram analfabetos ou semi-alfabetizados, mas entre os filhos maiores - (108) - apenas 07,4\% eram analfabetos. Consideran do-se, porém, que, entre a população rural, cuja renda é redu ziảa e cujos gastos limitam-se geralmente ao que é considerado mais importante para a sobrevivência, o que exclui despesas com assinaturas de jornais, parece óbvia a justificativa em relação à reduzida utilização da imprensa. Por outro lado, via noticiários da Rádio ou da TV, a população rural mantinha-se relativamente informada.

Dos dados apresentados sobre a frequência dos contatos com o meio urbano através do comparecimento habitual à cidade e/ou dos meios de comunicação utilizados, é possível inferir que a população mantinha contatos diretos e indiretos com a sede municipal e outros Municípios, com a Capital do Es tado e com o mundo.

Parece significativo observar que entre as res postas relativas à vida associativa na cidade encontra-se $100 \%$ de abstenção. Nenhuma das famílias entrevistadas tinha qualquer membro participando de clubes urbanos. Deste dado infe- 
re-se que as razões que ligam a população rural ao meio urbano situam-se ao nivel de necessidades e/ou interesses de consumo, de lazer individual ou do grupo familiar voltado para si mesmo, e/ou de interesses religiosos.

Outro dado a ser analisado refere-se às aspira cões em relação à possível transferência de moradia para a cí dade, o que vem objetivado no Quadro 23.

QUADRO 23. Aspirações da população rural em relação à possibi liảade de residência na cidade - Iruncínio de Osval do cruz - SP - 1981.

Aspirações declaradas

Número

○

Desejariam morar na cidade

39

50,0

Desejariam permanecer na roça

38

48,7

Não manifestaram qualquer preferência

01

01,3

Totais

78

$100 \%$

Tentando justificar suas aspirações os

Pais apresentaram diferentes motivos. Entre os que desejariam morar na cidade (39), houve mais do que uma justificativa apresentada, como o demonstra o Quadro 24. As preocupações com o trabalho e as possibilidades de melhor renda são as razões mais fortes apresentadas - 61,9\%. Destaca-se ainda, com 
23,8\%, a preocupação con o estudo dos filhos.

QUADRO 24. Justificativas apresentadas pela população rural com referência às aspirações relativas ao desejo de residir na cidade - Municipio de osvaldo Cruz. $-S P-1981$.

Tipo de justificativas

Nümero

$\%$

Preocupação com o estudo dos filhos 10 23,8

Possibilidades de emprego, facilidades do comércio, comodidade da vida, possi bilidades de "arriscar" u'a mudança econômica de vida

Desejo de experimentar outro tipo de vida, de melhorar o "status" social (a cidade é mais importante)

$06 \quad 14,3$

Totais

$42100 \%$

As justificativas referentes ao desejo de permanecer no meio rural também são significativas como o demons tra o Quadiro 25 . 
QUADRO 25. Justificativas apresentadas pela população referentes ao desejo de permanecer no próprio meio - Plunicípio de Osvaldo Cruz - SP - 1981.

Vantagens do meio rural: maior fartura e maiores possibilidades em relação à subsistência (podem plantar, pescar, desenvolver a criação donéstica); maior liber dade, tranquilidade, silêncio e segurança para a familia, especialmente para os filho pequenos

Desvantagens da cidade: tudo deve ser comprado, a vida é dificil para o pobre, são maiores as exigências de capacitação profissional, é grande a insegurança por causa dos crimes

Os 38 pais que preferem residir no meio rural também apresentaram mais de uma justificativa.

Considerando-se que 27,0\% explicitam sua visão negativa da cidade, e 61,9\% mostram as vantagens do meio urbä no, também implícitas nas justificativas referentes à preocupação com o estudo dos filhos - 23,8\%, cujos dados somados al Cançam 85,7\% (Quadro 24), infere-se que a visão valorativa a respeito da vida urbana entre a população rural parece projetar-se nitidamente através dos dados até aqui analisados. Fi ca demonstrado que existe a relação campo cidade entre a 
população da amostra. Esta relação desperta aspirações no sentido do êxodo rural e se reflete também na escolaridade. É o que se pretende demonstrar no Quadro 26 , en que são apresen tados em porcentagens, os dados sobre a escolaridade das famí lias cujos Pais foram entrevistados. Referem-se à escolarida de dos Pais (76 Pais vivos e 77 mães, totalizando 153 pessoas), 108 filhos maiores e 239 filhos menores em idade escolar.

QUADRO 26. Escolaridade na Familia Rural de UPAs Cafeicultoras - Município de Osvaldo Cruz - SP - 1981.

\begin{tabular}{|c|c|c|c|c|c|c|c|}
\hline \multirow{2}{*}{$\begin{array}{l}\text { Papel } \\
\text { Familiar }\end{array}$} & \multirow{2}{*}{$\begin{array}{l}\text { Analfa- } \\
\text { betos e } \\
\text { Semi al } \\
\text { fabeti- } \\
\text { zados }\end{array}$} & \multirow{2}{*}{$\begin{array}{l}\text { P1O- } \\
\text { BRAL } \\
\frac{0}{0}\end{array}$} & \multicolumn{2}{|c|}{ Séries do } & \multicolumn{2}{|l|}{ 1: Grau } & \multirow{2}{*}{ 29 Grau } \\
\hline & & & $1 a-2 a$ & $3 a-4 a$ & $5 a-6 a$ & $7 a-8 a$ & \\
\hline Pais & 42,5 & 07,2 & 21,6 & 28,7 & $-\cdots$ & -- & -- \\
\hline $\begin{array}{l}\text { Filhos } \\
\text { Maiores }\end{array}$ & 07,4 & --- & 13,0 & 52,8 & 12,1 & 05,5 & 05,5 \\
\hline $\begin{array}{l}\text { Filhos } \\
\text { Menores }\end{array}$ & 06,7 & -- & 05,9 & 27,2 & 04,6 & -- & 05,5 \\
\hline
\end{tabular}

Como é possivel observar, $42,5 \%$ dos pais são analfabetos ou semi-alfabetizados, enquanto apenas $07,4 \%$ dos filhos maiores o são. Entre os filhos menores nas mesmas con dições a porcentagem cai para $06,7 \%$, sendo que apenas 01,2\% são menores de 15 a 17 anos, enquanto $04,5 \%$ são menores de 07 
a 09 anos.

Os dados mostram que entre os menores que já abandonaram a Escola, 27,2\% haviam terminado a 4 ạ série, sendo que entre estes, 08,8\% deixaram a Escola ao terminarem a 3ạ série, enquanto 18,3\% o fizeram ao terminarem a 4ạ. Entre os Pais, dos $28,7 \%$ relacionados como tendo terminado a 4 ạ série encontram-se 16,3\% que deixaram a Escola ao terminarem a 3ạ série e 12,4\% que a deixaram ao terminarem a 4ạ série. As sim, a diferença entre Pais e Filhos Plenores que deixaram a Escola ao completarem a 4ạ série é de 05,9\%. Este acréscimo em relação aos filhos parece revelar o interesse dos pais em garantirem o estudo mínimo para a prole.

E importante observar que 03,7\% dos filhos maio res e 54,8\% dos menores em idade escolar ainda estão na Escola o que, entretanto, não significa que não venham a abandonà-la.

O Quadro 27 apresenta as respostas dos Pais sobre os motivos pelos quais enviaram ou enviam os filhos à Escola. O número de respostas excede o número de Pais; isto parece revelar a sua motivação a respeito do estudo dos filhos. $37,1 \%$ das respostas deixam perceber que vêem na Escola uma possibilidade e um meio de ascenção social, a partir da preparação para outras profissões. 17,2\% vêem na Escola um recurso para lidar com valores urbanos (assinar documentos en 
tendendo), 41,9\% das respostas referem-se à necessidade e importāncia do estudo.

QUADRO 27. Motivos que levaram os Pais a enviarem os filhos à Escola - Município de Osvaldo Cruz - SP - 1981.

Para que os filhos possam deixar a lavoura, preparando-se para outras profissões ou para empregos "menos duros" em que eles ganhem mais

Para que os filhos aprendam; o estudo é importante e necessário

Para que os filhos possari se defender (assi nar documentos, entendendo)

E pertinente observar que os Pais, não apenas enviam e se esforçam por manter na Escola a sua prole, por julgarem o estudo importante e necessário, como ainda mostraram o seu desejo em relação à continuidade dos estudos dos fi lhos e com respeito ao nivel de escolaridade que para eles al mejam. $87,2 \%$ dos Pais desejam que seus filhos continuem estu dando. Apenas $05,1 \%$ não querem que eles continuem estudando depois da 4 ạ série. Os restantes $07,7 \%$ explicaran que seus filhos menores já haviam deixado a Escola. 
Quanto aos motivos pelos quais desejavam a con tinuidade do estudo dos filhos, 59,0\% afirmaram que, embora seja dificil para a familia, querem que eles continuem para que melhorem de vida, possam preparar-se para adquirir uma "boa profissão" para ganhar mais. O Quadro 28 mostra as aspi rações dos Pais neste sentiảo.

QUADRO 28. Aspirações dos pais em relação à continujacie do estudo dos filhos - Município de Osvaldo Cruz - SP $-1981$.

O estudo é importante para que os filhos aprendam, melhorem de vida, adquiram uma boa profissão, mais rendosa

Querem, mas não justificaram

Querem, para fazerem a vontade dos filhos

04

05,1

Querem, mas lamentam que seja impossivel: os filhos têm que trabalhar para ajudar a manter a familia

Queriam, mas os filhos não quiseram

Não querem, porque os filhos precisam trabalhar

Não querem, pois é incômodo demais para a familia 
As respostas quanto ao nivel de estudos a que aspiram conduzir os filhos revelam a influência dos valores urbanos. 21,7\% dos Pais desejavam que os filhos terminassem Cursos Técnicos, enquanto $24,3 \%$ aspiravam a que terminassem Cursos Superiores, o que eles indicavam sob a expressão: "Até à Faculdade". Esta expressão significava para eles o nível de "Doutor", o que coinciae com as observações de MARTINS (1975). A porcentagem sobe a 30,6\% quando os progenitores expressam suas aspiracões em relação à carreira profissional dos filhos, como se percebe no Quadro 29. Apenas 10,6\% dos Pais não expressaram quaisquer aspirações em relação à profis são dos filhos. O nümero de profissões desejadas excede o nú mero de Pais porque alguns pensaram em mais de uma profissão. 
.144.

QUADRO 29. Aspirações dos Pais em relação à futura profissão dos filhos - Município de Osvaldo Cruz - SP - 1981.

Profissão

Número de 응 preferên-. cias

Doutor (médicos, advogados, dentistas, engenheiros-civis, agrōnomos, veteriná rios, contabilistas e/ou administrado= res de empresa)

Escriturários, cartorários, secretários, datilógrafos, bancários, funcionários

Professores

Qualquer profissão, menos a de lavrador

Profissões técnicas lentendidas como enfermeiros, farmacêuticos, mecânicos, téc nicos de TV)

Motoristas ou pilotos

Artes femininas (costureiras, bordadeiras)

$03 \quad 03,1$

Lavradores

$02 \quad 02,1$

Operários

$01 \quad 01,1$

Não expressaram aspirações

Respostas dos Menores Trabathadores

Entre os 150 Menores trabalhadores entrevistados, 93,4\% desejam morar na cidade, do que se infere a acentuada tendência à valorização dos padrões de vida urbana e à desvalorização do meio rural. Embora desejando residir na ci 
dade, 39,6\% dos Menores Trabalhadores preferem continuar desempenhando tarefas agrícolas como o demonstra o euadro 30 . Entretanto, como se pode observar no mesmo quadro, as profis-sões urbanas atraem 59,1\% dos Menores. Apenas 06,3\% não se expressaram sobre aspirações profissionais. Entretanto, Menores demonstraram desejar mais de uma Profissão, razão pela qual o número de respostas excede o número de entrevistados.

QUADRO 30. Aspirações Profissionais dos Menores Trabalhadores - Município de Osvaldo Cruz - SP - 1981.

Ocupações e/ou Profissões desejadas Nümero

Lavradores e/ou outros trabalhos no meio rural (pecuária, trabalhos mais adequados à própria força) 63 39,6

Empregadas Domésticas 16

Operários 14

Comerciários

Escriturários, secretários, bancários

Qualquer emprego mais fácil, na cidade

06

07,6

Artes Femininas

05

06,9

Doutor (advogado, médico, dentista)

04

Motoristas

Professores

Trabalhos Técnicos na cidade (eletricistas, mecānicos)

Trabalhos técnicos na agricultura

Não sabem 
Os dados sobre a escolaridade dos Menores Trabalhadores revelam que 46\% continuavam frequentando a Escola; $27,5 \%$ cursando a 3ạ série, 14,4\% cursando a 4 ạ e 14,4\% cursan do a 5ạ. Entre a 6ạ e a 8ạ séries estudavam 21,7\%, enquanto 04,3\% estavam no Curso Médio. E oportuno observar que entre os Menores Trabalhadores que frequentavam a $3 a ̣$ série encontravam-se 07 Menores que já estavam na Escola havia cinco anos e 03 que estavam havia seis anos. Um dos que estavam na 4ạ série já estava na Escola havia oito anos, ou seja, o dobro dos anos requeridos. O mesmo ocorria com um Menor Trabalhador de 17 anos, que havia dez anos estava na Escola, não tendo ainda passado da 5 ạ série.

Entre os Menores Trabalhadores 54\% haviam deixado de estudar. O maior indice de evasão ocorreu terminada a 4ạ série, correspondendo a $25,3 \%$ dos lenores entrevistados. Até à 5 ạ sẻrie permaneceram apenas $06,0 \%$.

\section{Resoostas dos alunos}

Entre os 116 alunos entrevistados nas Escolas, 33,6\% desejavam morar na cidade, enquanto 66,4\% preferiam ficar no próprio meio rural. Através do Quadro 31 é possivel ob servar como os alunos justificavam suas preferências. Estas mostram que os menores conhecem a cidade e seus valores, sabendo confrontar cidade-meio rural. 
QUADRO 31. Juizes de valor dos Alunos das Escolas Rurais sobre a vida na roça e na cidade - Municipio de osvaldo Cruz - SP - 1981.

1. Na rosa vivem em maior liberdade, a vida é mais sossegada, o ar é mais puro, não existe barulho, há muito tempo livre.

2. A vida na roça é alegre, gostosa, todos têm mais vizinhos, amigos e colegas para brincar e conversar, pode-se brincar a qualquer hora

3. Na roça podem trabalhar, têm mais verduras e frutas frescas do que na cidade, po dem plantar o que quiserem, não precisam comprar tudo

4. Na roça não existem tantos perigos como na cidade, onde existem mais ladrões

5. Querem ficar na roça porque estão acostú mados, podem trabalhar e ganhar dinheirō

6. Na cidade há mais movimento, mais gente, mais alegria, mais diversões; existem os carros, podem brincar com colegas, têm mais amigos

7. Na cidade não se precisa trabalhar debai xo do sol, vive-se mais sossegado

8. Na cidade existem os supermercados e mui tas casas; as coisas ficam mais perto das pessoas

9. Na cidade tem-se maior conhecimento das coisas, maiores oportunidades, lá existe mais dinheiro 
sionais baseadas em padrões e valores tipicamente

urbanos, conforme se pode verificar no Quadro 32. Entende-se por profissões urbanas aquelas que, habitualmente, são exercidas no meio urbano, bem como aquelas que, temporariamente exercidas no meio rural, possibilitam a transferēncia para a cidade, co mo é o caso do professor. O magistério destaca-se com 29,3\%, o que se explica pelo maior contato dos alunos com seus professores. O número de respostas excede o número de alunos, o que demonstra que alguns desejavam mais do que uma profissão, ou pensavam em escolher futuramente a que mais thes conviesse.

QUADRO 32. Preferências Profissionais dos Alunos do meio rural - Municipio de Osvaldo Cruz - SP - 1981.

\begin{tabular}{|c|c|c|}
\hline Profissões Preferidas & Número & \% \\
\hline Professor & 36 & 29,3 \\
\hline Esportista & 11 & 08,9 \\
\hline Doutor & 10 & 08,2 \\
\hline $\begin{array}{l}\text { Profissões técnicas urbanas (mecânico, } \\
\text { eletricista, aviador) }\end{array}$ & 10 & 08,2 \\
\hline Artes Femininas & 09 & 07,4 \\
\hline $\begin{array}{l}\text { Escriturário, bancário, secretário, } \\
\text { contador, desenhista }\end{array}$ & 08 & 06,5 \\
\hline Dona de casa & 07 & 05,7 \\
\hline Isavrador & 06 & 04,9 \\
\hline Químico, enfermeiro & 04 & 03,2 \\
\hline Artista & 03 & 02,4 \\
\hline Operārio & 03 & 02,4 \\
\hline Comerciārio & 02 & 01,6 \\
\hline Outras & 14 & 11,3 \\
\hline Totais & 123 & $100 \%$ \\
\hline
\end{tabular}


Conclusões da anälise da variável x.5. RelaGüo campo-eidade

Considerando-se:

19) que a relação campo-cidade foi verificada em quantidade e qualidade significativas, demonstrando a influência do mo do de vida urbano sobre a população;

29) que existe entre a população significativa tendência ao desejo do êxodo rural, estimulado pela visão da vida urba na e/ou pela precariedade de conforto e de satisfação eco nômica oferecidos pelo meio rural;

39) que a comparação entre os niveis de escolaridade de Pais e filhos demonstra o aumento do interesse pela Escola;

49) que as aspirações profissionais constatadas revelam preferências por profissões ligadas à vida urbana, sendo a Escola considerada como um meio capaz de preparar para a formação profissional adequada à cidade;

Parece possivel ter-se por validada a hipótese H.6. que afirma: "A escolarização do Menor será tanto mais ha bitual e perseverante quanto mais intensa for a relação campo -cidade no meio rural".

7.2.7. Anālise da Variável x.6. Organização do Ensino Rurat

Parece necessärio, antes de se passar à análi- 
se da Variável, apresentar algumas informações gerais sobre os tipos de Escolas Rurais existentes, sobre o sistema de nomeação de Professores, Programas de Ensino, e atendimento às necessidades específicas do meio rural por parte da Delegacia de Ensino.

Segundo a classificação elaborada pela Coordenadoria de Estudos e Normas Pedagógicas (CENP) do Estado de São Paulo, as Escolas Rurais apresentam quatro tipos aiferenCiados: Escolas Agrupadas (EEPG-A), Escolas Isoladas (EEPG-I), Escolas de Emergência (EEPG-E) e as UEAC (Unidades Escolares de Ação Comunitária) .

As Escolas Agrupadas são unidades escolares que mantêm de 4 a 7 classes, sem ultrapassar a 6 ạ série. São vinculadas à Delegacia de Ensino, sendo dirigidas por um professor da própria Escola, habilitado para o Cargo de Diretor. As Escolas Agrupadas mantêm um servente e um escriturário além do pessoal docente. Normalmente estão localizadas nas se des dos bairros rurais mais populosos, nas vilas ou nas sedes dos distritos.

As Escolas Isoladas contam com um só professor nível I e uma só classe onde é ministrado o ensino destinado a alunos de uma ou mais séries do primeiro grau, sem ultrapas sar a 4 ạ série. 
Nas Escolas de Emergência, como nas Isoladas, é ministrado o ensino a alunos de uma ou mais séries do primeiro grau, sem ultrapassar a 4 ạ série, por um só professor admitido em caráter temporário. Sendo de emergência, a Escola será mantida se atender à frequência média de 12 alunos, podendo ser extinta na falta destes ou quando for possivel o seu remanejamento para outras unidades escolares.

As UEAC se constituem em um tipo especial de escola rural, criado pelo Programa de Ensino do Vale do Ribei ra, em 1971, sob a responsabilidade da Secretaria da Educação. Nas UEAC o professor deve desenvolver, além das atividades formais do ensino, um trabalho direto junto à comunidade, ten do en vista incentivá-la a se organizar para solucionar seus problemas vitais.

No Municipio de Osvaldo Cruz existiam 02 Escolas Agrupadas de bairros rurais, 26 Escolas Isoladas, e 05 Es colas de Emergência.

As Escolas Isoladas do Municipio ficam vincula das, para efeitos administrativos, a uma escola-sede, entendi das como tais as Escolas urbanas de 10 Grau situadas na sede do Município. Para efeito de ensino a vinculação é mantida com a Delegacia de Ensino (DE), através de Supervisores de En sino.

A DE, que está vinculada à Divisão Regional de 
Ensino de Presidente Prudente, contava com 04 Supervisores, sendo 02 concursados e 02 efetivos por enquadramento. Todos os supervisores eram portadores de diplomas de cursos superio res, sendo que 02 haviam-se graduado em Cursos de Pedagogia e os outros 02 haviam cursado outras áreas. Um dos Supervisores também havia feito um curso de especialização.

Segundo as informações da DE a nomeação dos professores é feita por títulos, por títulos e provas, ou por decreto, devendo distinguir-se as nomeações por concurso de ingresso e acesso e a destinação de cargos lem relação aos efetivos).

Nos últimos 03 anos, em virtude de inúmeros concursos havidos para ingresso, acesso, remoção e provimento de cargos, foram efetuadas frequentes mudanças de professores. A medida foi considerada como excepcional pela DE.

Foram visitadas para efeito da Pesquisa 02 Escolas Agrupadas, 09 Escolas Isoladas e 01 Escola de Emergência, sendo entrevistados 14 professores. Em relação às mudan ças de Professores, ocorridas nas Escolas visitadas, o Quadro 33 mostra que a medida considerada excepcional atingiu 57,2\% dos professores no ano de 1981. 
QUADRO 33. Tempo de nomeação dos Professores para classes nas Escolas visitadas - Município de Osval do Cruz - SP - 1981.

Tempo na Unidade Escolar ou classe
Número de Professores
$\%$

57,2

menos de 01 ano

08

21,4

02 a 05 anos

03

21,4

12 a 17 anos

03 14

Totais

$100 \%$

Segundo as informações oferecidas pela DE, esta propõe aos Professores um Programa Geral de Ensino, tendo em vista garantir a sequencia dos conteridos e a orientaça dos Professores. Não há obrigatoriedade quanto à aceitação desses Programas, pois a Lei $201 / 78$ garante a liberdade didática e pedagógica do Professor. Os Programas são considerados como roteiros que os docentes podem desenvolver segundo as pecu liaridades de sua clientela escolar; foram elaborados por equipes de Professores da própria DE e são fornecidos em cópias mimeografadas. A DE só exige o desenvolvimento do Programa proposto quando o docente o adota. Este pode optar por elaborax o próprio programa, visando o atendimento mais específico das necessidades dos seus alunos, devendo, neste caso, apresentá- ro à $\mathrm{DE}$. 
Segundo informações da DE, os currículos das Escolas Rurais identificam-se com os das Escolas Urbanas de 1ạ à 5 ạ série, abrangendo as seguintes áreas de ensino-aprendizagem: a. comunicação e expressão; b. integração social; c . iniciação às ciências; d. ensino religioso. A área de comuni cação e expressão compreende as disciplinas: Lingua Portuguesa, Educação Artística e Educação Física. Estas duas últimas começam a ser ministradas a partir da 5ạ série. A área de in tegração social compreende: História, Geografia, Educação Moral e Civica e Organização Social e Politica Brasileira. A ârea de iniciação às ciências compreende as disciplinas: Ciên cias Físicas, Biológicas e Programas de Saúde, e a Matemática. O ensino religioso faz parte do currículo, sem ser obrigatório, com 01 aula por semana.

Estas informações parecem confirmar as observações de PEREIRA (1971 - 183).

Na medida do possivel, segundo informações da DE, as Escolas procuram manter horários condizentes com as necessidades dos alunos, os quais são dispensados das aulas de Educação Física e têm liberdade de opção quanto ao período escolar. Em um mesmo prédio funcionam, em alguns casos, pela manhã e tarde, constituindo-se cada periodo em uma Escola di $\underline{\underline{S}}$ tinta da do outro, o que possibilita a opção quanto ao pexiodo de aulas. 
Visando o atendimento à população Escolar a DE mantém, juntamente com a Prefeitura Municipal, o sistema de transporte que possibilita o acesso às unidades escolares dos Bairros Rurais e também às Escolas Urbanas.

Colaborando com a Secretaria da Educação a DE promove o levantamento das necessidades relativas a prédios escolares, mobiliário, número de classes e materiais didáticos; colabora ainda na área da saúde participando nos programas de vacinação e da oferta de possibilidades de exames de vista à população escolar.

Condigões materiais das Escolas Visitadas

Os prédios das Escolas visitadas eram construi dos em alvenaria. Sua estrutura obedecia a um mesmo padrão. Excluindo-se as Escolas Agregadas, em cuja estrutura havia de 4 a 5 salas de aula, as Escolas apresentavam uma, com capacidade média para 30 alunos; em todas existiam quadros-negros fi xos. As carteiras eram individuais, com exceção de 01 Escola na qual cada carteira comportava dois alunos. Em todas as Es colas havia uma cozinha destinada ao preparo e distribuição da merenda escolar, pela qual eram responsáveis merendeiras da própria UPA contratadas pela prefeitura ou pelo Estado. Te to e pintura do prédio apresentavam bom estado de conservação. Em 75,0\% das Escolas a água, provinda de fonte ou de poço, era encanada, mas não era filtrada e os alunos dela bebiam habitualmente. Em 25,0\% a água de poço era retirada en bal- 
des. As unidades escolares dispunham de fossas sanitárias, situadas em local próximo ao prédio; em 50,0\% das unidades eram equipadas com vasos de louça enquanto em $08,4 \%$ os vasos eram de caixote. 41,6\% não dispunham de vaso algum, estando em condicões materiais precárias e oferecendo perigo aos usuá rios.

O acesso às Escolas era considerado fácil no período das secas, tanto para os alunos quanto para os profes sores. No periodo das chuvas tornava-se dificil para os alunos em 58,3\% das unidades escolares, enquanto que para os Pro fessores apenas em 16,6\% ocorria a dificuldade. Na única Escola de Emergência visitada, o acesso tornava-se de todo impossivel nas chuvas, sendo dificil na seca, o que tornava fre quente a ausência do Professor.

os dados levam ainda a constatar a relativa proximidade das unidades escolares: em 44,6\% das UPAs a distância da Escola em relação à sede era de $300 \mathrm{~m}$ a $2 \mathrm{~km}$; em 21,1\% das UPAs esta distãncia aumentava para 03 a $04 \mathrm{~km}$. São distâncias consideradas pequenas pelos próprios rurícolas, ha bituados a grandes caminhadas. Apenas em 04,6\% das UPAs a distância entre a Escola e a sede atingia de 05 a 06 km. Não foi possivel obter informações a respeito, em relação a 24,7\% das UPAs. 


\section{Entrevistas com os Professores}

Entre os 14 Professores entrevistados, todos eram formados segundo os padrões do Ensino no Estado de São Paulo: 71,4\% eram normalistas nivel 20 Grau, normalmente chamados Professores nivel I; entre estes, 40,0\% haviam frequentado e terminado Cursos de Especialização e de Aperfeiçoamento. $21,4 \%$ dos professores eram graduados em Cursos de pedago gia, de Administração e de Orientação Escolar; 07,2\% eram diplomados em Curso Superior de Letras. Nenhum dos Professores entrevistados recebera formação relativa ao meio rural. Todos residiam fora da área rural; alguns acumulavam outras ativida des laborais de caráter urbano, além do magistério.

87,7\% dos Professores declararam seguir os Pro gramas da DE, adotando livros comumente usados nas escolas da cidade.

Ao se procurar saber se a Escola mantinha algum Programa que atingisse a Comunidade rural, apenas 21,4\% dos professores responderam afirmativamente, citando bailes e quermesses no Centro Comunitário cos Bairros Rurais, Sistema de Contribuições para a Merenda Escolar, Grupos de Artesanato, Aulas de Religião extra-escolares. 42,8\% dos Professores afirmaram não desenvolver qualquer programa, alegando: 19) a existência de apenas um docente para uma classe com mais de 30 alunos; 29) distância entre a Escola e a residência do Pro fessor; 39) falta de quintais domésticos apropriados à horta 
familiar. Em 35,8 das Escolas os Professores não responderam à questão.

Como se percebe, não eran promovidos programas diretamente ligados à agricultura ou ao meio rural. Os Professores procuravam manter contato com os Pais dos alunos através de entrevistas quando estes vinham voluntariamente à Escola, quando eram chamados através de bilhetes ou nas reuniões de Pais.

\section{OS PROGRAMAS}

A leitura dos Programas da área de Comunicação e Expressão, da 1ạ à 4 ạ séries deixa ver a falta de preocupação e/ou de relacionamento de idéias voltadas para o meio rural. Ainda que mostrem alguma flexibilidade nesse sentido, como é possivel observar em orientações como: "identificar as caracteristicas próprias de objetos e animais familiares; de $\underline{s}$ crever cenas" (programa da 4 ạ série); utilizar "gravura de preferência que retrate situações vividas pelas crianças ou que possam ser por elas observadas" (programa da 3ạ série) ; "história da plantinha que nasce, cresce, floresce" (programa da 2a série"; "exploraçaõ de figuras, objetos e meio ambien .. te" (programa da 1 ạ série), as orientações nada sugerem em re lação ao meio rural. Abertas que são para esse meio, perdem-se entre centenas de outras que não dão margem a relações com a agricultura, a menos que cada professor seja capaz de iniciativas pessoais e de invenções múltiplas, criando situações 
ligadas ao meio. Como foi visto, entretanto, 87,7 응 dos professores adotam livros comumente usados nas escolas da cidade e estes apresentam sobretudo situações urbanas. E o que aparece em orientações dos programas como: "ensinar a passar telegramas; estabelecer diálogos a partir de encenação de ligações telefônicas", "escolha de texto escrito por um adulto culto", "organizar artigos pequenos para jornal, dos tinos: "vende-se", "aluga-se", "animal perdido", etc., "fazer relatō rios em situações funcionais, aceitando-se a elaboração lógico-sequencial dos mesmos".

Quanto aos resultados do ensino-aprendizagem, relacionados com os programas, observa-se entre os alunos a preocupação com a leitura e as "contas".

Respostas dos alunos entrevistados nas Escolas Considerados entre os 116 alunos entrevistados, os 90 que cursavam a $3 a ̣$ e a 4 ạ série, os quais constituiram $77,6 \%$ dos entrevistados, foram obtidas as seguintes respostas que mostram as preferências dos alunos em relação ao que aprendem: gostam de contas, tabuada, problemas, sistema métrico e decimal, utilização da régua, porcentagem, àrea, perímetro, geometria. Não aparece, em relação à matemática, qualquer alusão à sua aplicação no meio rural. Gostam de assinar, ler, escrever, entender anüncios, redigir cartas, bilhetes e recados para a familia, separar silabas, fazer composições e ditados, escrever telegramas. 
27,2\% declararam gostar de brincar com bolas e outros jogos. 46,6\% dos alunos afirmaram gostar de noções de Ciências, Higiene e Saúde. Nesta área nuito se poderia fazer em relação ao meio rural; não aparecem, contudo, quaisquer referências ao neio. 05,1\% declararam gostar de aprender noções sobre Município e Estado e de aprender a fazer compras.

$78,4 \%$ dos alunos declararam gostar mais do tra balho escolar do que de trabalhar na roça ou em casa. Este é um dado significativo em relação à valorização da Escola e à desvalorização do meio rural. Demonstra que a população esco lar sente-se mais ligada à Escola do que à Agricultura, não apenas em vista desta declaração, como tambéra pelo conteúdo programático que conseguem internalisar, desligado do meio ru ral, e pelo qual mostram especial preferência.

\section{As respostas dos Menores Trabaihadores}

Entre os Menores Trabalhadores Agricolas entre vistados, 56,6\% abandonaram a Escola ou nunca a frequentaram. Apenas 50,6\% declararam os motivos desse abandono, apresentados no Quadro 34. O trabalho e as mudanças da familia foram as razões que mais pesaram como justificativas da evasão esco lar. Somadas suas incidências, alcançam 55,3\%. E interessan te observar que as mudanças da Eamília foram quasi sempre motivadas pelo trabalho dos pais; portanto, o trabalho aparece como fator que influencia fortemente a evasão escolar. A dis tância da Escola, o período noturno lo que significa que a Es 
cola era urbanal, a falta da 4 ạ ou da 5ạ séries nas Escolas frequentadas e ao alcance dos Menores, são razões que dizem respeito à própria Escola, atingindo uma incidência de $28,9 \%$ As causas apresentadas no liltimo item do quadro 34, com 11,8\% parecem demonstrar desinteresse pela Escola: "não quiseram. Achavam que já tinham muita idade, não gostavam".

E possivel perceber, através das razões apresentadas pelos Menores Trabalhadores, a acentuada relação "trabalho-escolarização" no meio rural, em que a atividade agricola ocupa o primeiro lugar, em detrimento da Escolarizaçâo . 
QUADRO 34. Causas da evasão escolar dos Menores Trabalhadores Agrícolas - Município de Osvaldo Cruz - SP - 1981

\begin{tabular}{|c|c|c|c|c|c|c|}
\hline $\begin{array}{c}\text { Faixa } \\
\text { etária }\end{array}$ & $07-09$ & $10-12$ & $13-15$ & $16-17$ & Totais & $\%$ \\
\hline Trabalho & -- & 02 & 14 & 12 & 28 & 36,9 \\
\hline Mudanças da Familia & 02 & 01 & 09 & 02 & 14 & 18,4 \\
\hline Distância da Escola & -- & 01 & 07 & 05 & 13 & 17,1 \\
\hline $\begin{array}{l}\text { A Escola era noturna } \\
\text { tinham medo ou sono }\end{array}$ & -- & -- & 05 & 02 & 07 & 09,2 \\
\hline $\begin{array}{l}\text { Não havia } 4 \text { ạ ou } 5 a ̣ \\
\text { séries na Escola que } \\
\text { frequentavam }\end{array}$ & -- & 01 & 01 & -- & 01 & 02,6 \\
\hline $\begin{array}{l}\text { Doença, ou falta de } \\
\text { permissão do pai }\end{array}$ & -- & -- & 01 & 02 & 03 & 04,0 \\
\hline $\begin{array}{l}\text { Achavam que tinham ja } \\
\text { "muita idade", não } \\
\text { gostavam }\end{array}$ & - & - & 03 & 06 & 09 & 11,8 \\
\hline Totais & 02 & 05 & 40 & 29 & 76 & $100 \%$ \\
\hline
\end{tabular}

$64,5 \%$ dos Menores Trabalhadores que deixaram a Escola desejavam e esperavam voltar a estudar visando empregos melhores na cidade e/ou melhores profissões entendidas co mo: advogado, professor, dentista, médico, bancário, escriturário, datilógrafo. 44,9\% afirmaram que gostavam de estudar e desejavam aprender mais e obter diploma do 19 e/ou 29 grau.

Os dados revelam a forte tendêndia dos Menores Trabalhadores no sentido de expetativas de ascensão social e 
de êxodo rural.

o quadro 35 mostra tais expetativas.

QUADRO 35. Expetativas dos Menores Trabalhadores en relação ao retorno à Escola - Município de Osvaldo Cruz $-S P-1981$.

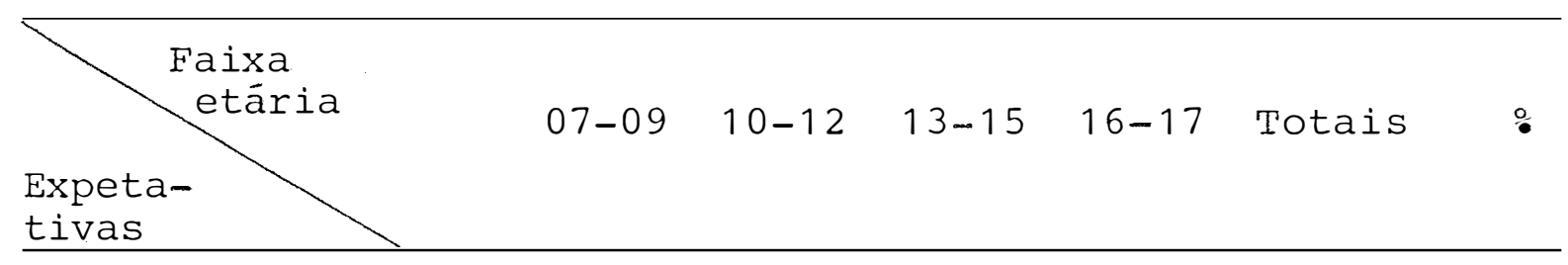

Aprender mais e ob-

ter uma profissão ou

emprego melhor na

cidade

$\begin{array}{llllll}- & 02 & 11 & 11 & 24 & 49,0\end{array}$

Aprender mais, pois

desejam alcançar o

diploma do 1\% e/ou

do 2 g grau

02

03

1106

2244,9

Conseguir melhor

serviço na roça

$\begin{array}{llllll}- & - & 0 & 0 & 01 & 02,0\end{array}$

Não declararam

$--$

02

0204,1

Totais

02

05

25

17

$49 \quad 100 \%$

Respostas dos Pais entrevistados

A relação entre o trabalho e a escolarização

também aparece com grande incidência nas respostas dos Pais. O Quadro 36 mostra que as razões "trabalho" e "mudanças da Fa milia" foram as que mais pesaram para a evasão escolar dos fi 
lhos. Somadas as duas incidências o resultado atinge a 52,7\%, dado bastante significativo. Os Pais apresentaram mais de uma justificativa, motivo pelo qual aparecem 93 respostas de apenas 78 Pais.

QUADRO 36. Razões atribuidas pelos Pais para a evasão escolar definitiva dos filhos - Municipio de osvaldo Cruz- SP - 1981.

\begin{tabular}{lcc}
\hline Justificativas & Nümero & $\%$ \\
\hline Necessidade de trabalho & 36 & 38,7 \\
Mudanças da família & 13 & 14,0 \\
Distancia da Escola & 10 & 10,8 \\
$\begin{array}{l}\text { Era preciso que os filhos fossem à } \\
\text { cidade para estudarem à noite }\end{array}$ & 14 & 15,1 \\
O filho "não tinha cabeça" & 19 & 20,4 \\
O filho ficou doente & 01 & 01,0 \\
\hline Totais & 93 & $100 \%$ \\
\hline
\end{tabular}

A maior incidência, 38,7옹, recái sobre o traba Iho. Se for levado em consideração o fato de que as mudanças da familia tiveram sua origem nas dificuldades de trabalho dos Pais, os quais mudavam porcue procuravam atividade mais rendo sa, ou forque haviam sido despedidos de outras UPAs e que, $57,6 \%$ das Familias mudaram de duas a mais vezes nos últimos 5 
anos, o dado cresce de significação. Houve, no cômputo geral, um total de 148 mudanças, o que corresponde, em média, de 3 a 4 mudanças por familia. Embora algumas familias nunca ti vessem mudado, outras mudaram-se de 6 a 7 vezes, havendo uma que se mudou 10 vezes. Observe-se que, entre os Pais que se mudaram, 57,7\% eram parceiros ou parceiros transformados em diaristas residentes.

Respondendo à questão: "as mudanças da famíIia têm atrapalhado o estudo dos seus filhos?", 38,4\% dos Pais responderam afirmativamente, apresentando as seguintes razões: a. mudando de lugar, os filhos tiveram que mudar de Escolas e de Professores o que deu origem às repetências e ao desestímulo nos estudos; b. ficando a outra Escola muito distante, e faltando vagas para matricular os filhos no meio do ano, estes tiveram que deixar a Escola, não voltando mais a frequentá-la.

Por outro lado, face à questão: "O senhor acha que vale a pena ficar no mesmo lugar bastante tempo para os filhos poderem estudar?", 91,0\% responderam afirmativamente. o dado mostra que, se pudessem, os Pais não mudariam de residência para favorecerem o estudo dos filhos, demonstrando que eles valorizam a Escola. Entretanto a necessidade do trabalho provoca a mudança e a consequente evasão escolar. 
tange à importância do estudo, às razões da evasão escolar dos filhos (trabalho, mudanças da familia) resta perguntar se o contato habitual entre Pais e Professores estaria direcionando as respostas dos primeiros. O Quadro 37 mostra a relam ção entre Pais e Professores. Para a questão: "O senhor já conversou com o Professor de seu filho(a)?", foran obtidos os seguintes resultados:

QUADRO 37. Contato dos Pais com os Professores - Municipio de Osvaldo Cruz - SP - 1981.

\begin{tabular}{lcc}
\hline \multicolumn{1}{c}{ Respostas } & Nümero & $\frac{0}{0}$ \\
\hline De vez em quando conversam & 30 & 38,5 \\
Nunca conversa ram & 23 & 29,5 \\
Conversam muitas vezes & 05 & 06,4 \\
Conversaram uma vez & 02 & 02,5 \\
Sempre conversa & 01 & 01,3 \\
Não responderam & 17 & 21,8 \\
\hline Totais & 78 & $100 \%$ \\
\hline
\end{tabular}

Considerando-se as abstenções, as respostas dos que nunca conversaram ou conversaram uma vez com o Profes sor, obteve-se em termos de porcentagem, 53,8\% do total de respostas e abstenções. O dado parece expressivo, podendo ma nifestar desinteresse dos Pais quanto à vida escolar dos fi- 
lhos. Entretanto, os resultados da questão: "O senhor já foi a Escola de seu filho?", apresentados através do Quadro 38, parecem demonstrar acentuado interesse, incentivado pelo contato dos Pais com a Escola. No quadro é possivel observar a abstenção de 14 entrevistados, entre os quais estava um Pai cujos filhos menores já haviam deixado a Escola.

QUADRO 38. Frequência dos Pais à Escola dos Filhos - Município de Osvaldo Cruz - SP - 1981.

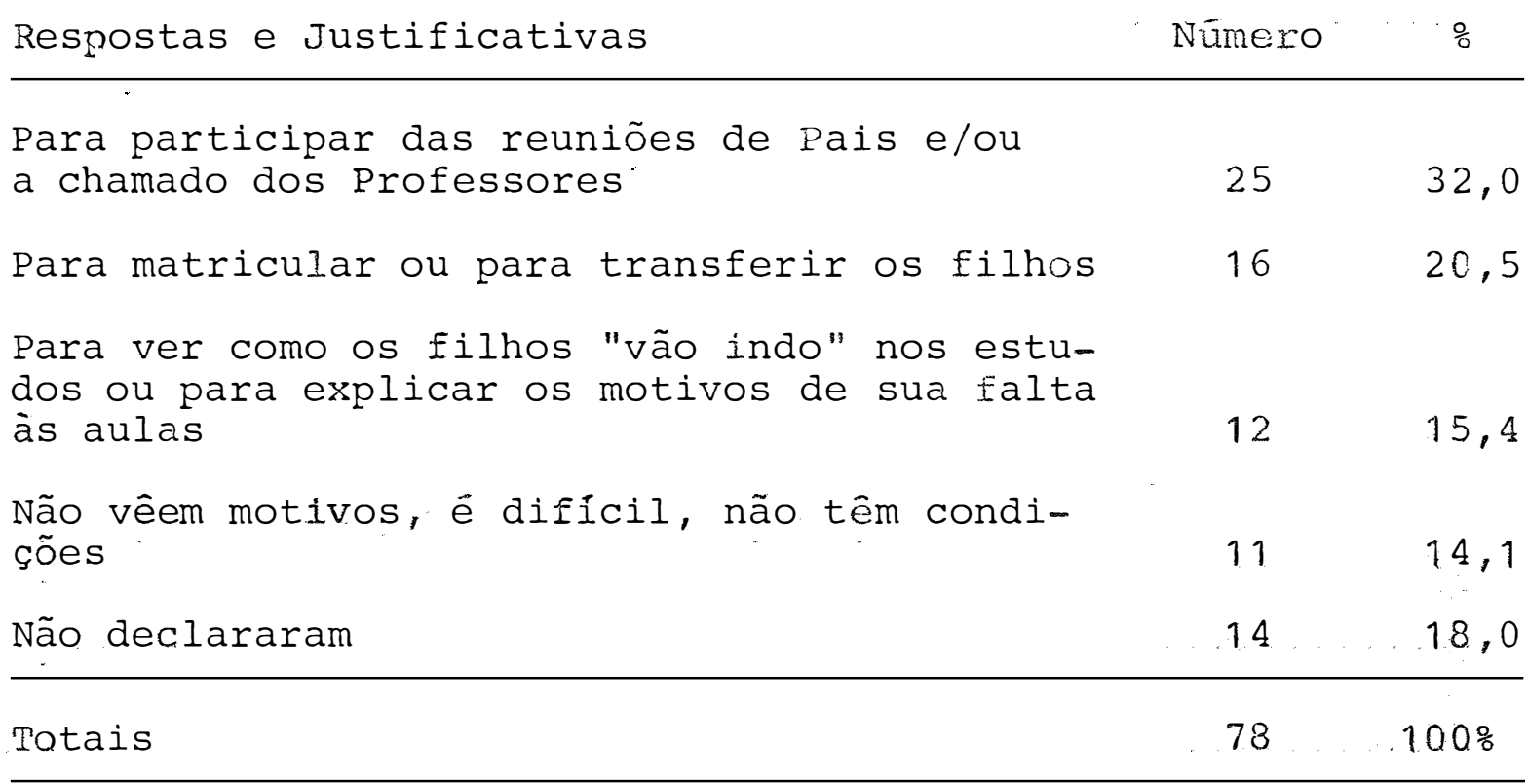

Onze Pais nunca foram à Escola, justificando-se com a explicação: "não vejo motivos", ou "não tenho tempo, nem condições". Entretanto, 37 deles, isto é, 47,4\% afir maram terem ido para participar de reuniões, obter informações ou apresentar explicações o que, sem düvida, manifesta 
interesse.

O dado parece demonstrar que a população rural da amostra não procura a Escola apenas ritualmente e sim com a finalidade de participar do processo educativo dos filhos.

Considerando-se, em retrospeto (ver Quadro 27) os motivos que levaram os pais a enviar os filhos à Escola, ressaltam, com 41,9\%, a importância do estudo e, com 37,1\% 0 desejo de que os filhos deixem a lavoura preparando-se para outras profissões ou empregos menos duros. Observando-se as justificativas que apresentam em relação às aspirações à continuidade do estudo da prole (ver Quadro 28) ver-se-á que se destacam, com a incidência de 59,0\%, as justificativas que mostram aspirações por melhores e mais rendosas profissões ; se forem revistas as respostas em relação às aspirações pela profissão dos filhos, ver-se-á que 30,6\% desejam que estes se jam doutores, 21,1\% aspiram por profissões burocráticas para a prole, 15,6\% desejam fazer dos filhos professores, 05,3 an seiam por profissões técnicas e 07,4\% aceitam qualquer profis são, menos a de lavrador.

Conclusão da análise $x .6$. em sua relação com a hipótese H.?.

Considerando-se que:

- Onsino Rural, na concretização de suas funções utiliza re cursos administrativos (humanos: professores suficientemen- 
te titulados; materiais: transporte, merenda escolar, mobiliário, material didático, etc.; disposições normativas como: horários adequados, flexibilidade quanto à matrícula em períocio compatível com as prōprias necessidades), que facilitam e incrementam a escolarização, a qual apresenta na re gião uma tendência à elevação de sua taxa e correspondente diminuição da taxa de evasão escolar definitiva;

- os professores, embora suficientemente titulados, não têrı formação que thes possibilite ministrar ensino adequado ao meio rural e promover programações extra-classe também rela cionadas com o meio;

- o conteúdo programático das disciplinas apenas tangenciam, e raramente, questões relacionadas com o meio rural;

- a internalização ensino-aprendizagem, por parte dos alunos, manifesta preferências que não dizem respeito em nada ao meio rural;

- embora o trabalho tenha afastado da Escola 56,6\% dos Menores Trabalhadores, 64,5\% dentre eles desejam e esperam retornar aos estudos visando a ascenção social, via profissões urbanas ou diplomação aos níveis de 19 e 29 graus de Ensino;

- Os Pais valorizam a Escola pela importância do estudo e pela possibilidade que consideram oferecer em relação à ascen 
são social e ao êxodo rural para os filhos;

é possivel inferir que a Escola é portadora e veiculadora de valores urbanos, tendendo a negar o meio a que servem, constatação que reforça as de GRILO e MARTINS, citadas neste estudo.

Estas considerações confirmam a hipötese H.7.: "a escolarização no meio rural, influenciada pela organização do Ensino, direciona a população escolar e a comunidade rural à negação do próprio meio, pela falta de estímulos aos valores e ao trabalho rural motivando, consciente ou inconsciente mente expetativas urbanas". 


\section{CONCLUSOES}

A pesquisa constatou que a força-de-trabalho do menor é habitualmente utilizada em todos os tipos de unida des Produtivas Cafeicultoras, encontrando-se percentualmente em maior intensidade nas Empresas Agrícolas Familiares, integrando sobretudo o trabalho familiar sem qualquer remuneração e onde é também maior sua utilização como Boia-Fria. Raros são os assalariados, remunerados com um ou meio salário, embora tenham idade prevista em lei para perceberem salário integral. Eventualmente trabalham também como Boias-Frias. Realizam todas as atividades agricolas requeridas pela cafeicultura, excetuando o trabalho de tratorista.

Os periodos agrícolas do café e das culturas in tercalares da região favorecem a ocupação diversificada do me nor durante todo $\circ$ ano. Este inicia o trabalho entre os 10 e 12 anos, havendo em pequena porcentagem os que começam entre 7 
e 9 anos, constituindo-se exceções alguns que, desde os 6 anos começam seu trabalho na lavoura. Esta participação intensifica-se entre os 13 e os 15 anos, quando além de trabalharem em maior porcentagem, passam a fazê-lo em horärio inte gral. O trabalho infanto-juvenil na cafeicultura è motivado em razão da necessidade de contribuir para a renda familiar.

Verificou-se entre os agricultores a predorainância de parceiros, na grande maioria reduzidos a parceiros subordinados, categoria que apresentou a maior participação do menor no trabalho familiar, o que tencle a aumentar na razão di reta da maior espoliação do produtor ou do trabalhador rural, e que resulta, para o capital, em redução do custo operacional da mão-de-obra e, portanto, do custo operacional da produção.

Verificou-se que os parceiros autônomos foram transformados em parceiros subordinados e, significativas por centagens, em diaristas residentes, o que demonstra a crescen te proletarização do homem rural na região. Desamparado juridicamente, sem carteira assinada, sem assistência previdenciäria, sem esperança de aposentadoria, reduzido a níveis cada vez mais baixos e menos rendosos, o agricultor empenha toda a força-de-trabalho da família, inclusive dos filhos menores, conseguindo apenas sobreviver.

Despojado da terra que produz mercadoria para o mercado interno e externo, o homem rural vê-se obrigado a 
estabelecer com a cidade, sede do Município, as relação de compra dos produtos de subsistência que não pode produzir. Sendo baixo o seu poder aquisitivo, não pode armazenar, o que - leva a frequentar semanalmente os centros de fornecimento do meio urbano. Esse relacionamento aliado à influência dos meios de comunicação, suscita novas necessidades, desejo de usufruir dos bens urbanos, esperança de uma ascensão social que o liberte da faina agrícola, pouco compensadora e desgastante. Percebe que precisa instrumertalizar-se, diretamente, ou através de sua prole.

A pesquisa constatou também a insatisfação em que vive o homem rural e os seus anseios por melhores condições, manifestados nas expetativas de profissões urbanas para os filhos, menos penosas e mais rendosas que a do lavrador, e que ofereçam possibilidades de seguridade social.

Motivado por estes anseios o agricultor vê na Escola um instrumento para esta ascensão social. Não são uni camente os Pais que têm esta visão da Escola e que desejam, através dela, alcançar melhor status. Transmitem-na aos fiIhos. Esta visão motiva a escolarização e a frequência escolar que, mesmo durante a colheita è mantida, na região, em um nível de $80 \%$, segundo informação dos professores. Os que abandonaram a Escola, por razões de trabalho, desejam voltar visando preparar-se para empregos urbanos. Embora estimulan- 
do tais expetativas, a Escola Rural não qualifica o aluno para isso. Carrega contradicoóes como a pröpria ideologia de que estä impregnada.

100: dos Pais não conseguiram ultrapassar a 4. série e muitos siquer a alcançä-1a. Jä os filhos são manti dos em maior porcentagem na éscola, embora os maiores tenham cursado apenas até a 4 à série. Na Região, alguns dos menores vão sendo mantidos no estudo atẻ o segundo Grau, sendo alimen tadas expetativas de que alcancem o rexceiro.

A Escola no meio rural, influenciada pela orga nização geral do Ensino, na qual estä subjacente a ideologia dominante, direciona a população escolar e a comunidade rural no sentido da negação do próprio meio. Residindo na cidade e nela assumindo outros encargos, acumulando magistério rural e atividades urbanas para complementarem a pröpria renda, cons ciente ou inconscientemente, os professores, formados e titulados segundo os parâmetros do Estado, deixam de estimular os valores e o trabalho rurais, motivando, através dos conteúdos programáticos, expetativas urbanas, veiculando valores da cidade e rejeitando o meio a que servem.

Näo se pode afimar que exista entre os Professores a consciência do que sua açäo representa no meio rural. Mas é possivel concluir, pelos dados da pesquisa, que a 
.175 .

Escola nesse meio serve à preparação de futuros trabalhadores que, proletarizados, venham a se constituir no chamado exérci to de reserva exposto à exploração do capital industrial. 


\section{BIBLIOGRAFIA CITADA E CONSULTADA}

AlvTUNIASSI, M.F.R. , 1981. O trabalhador Mirim e a Modernazi zação da Agricultura Paulista. in: CERU. Caderno n! 11, 1. série. São Paulo. p. 75-122.

ARAUJO MARTIIS, M.L., 1978. A Participação do Menor como For ça de Trabalho no Setor Agrícola. in: Mäo de obra volante na Agricultura. IV Encontro Nacional de Estudos Rurais. UNESP/Botucatu. (Edição mimeografada) p. 229-259.

BREJON, M., org. 1978. Eetrutura e Funcionamento do Ensino de $1 \%$ e 2 Graus. 11.a edição, são paulo, Pioneira. 315 p. CALDEIRA, C., 1960. Menores no Meio Rural. Rio de Janeiro, Centro Brasileiro de Pesquisas Educacionais, MEC. 190 p. CAMPANHOLE, A., org. 1971. Consolidacão das leis do Trabatho. 30: edição. São Paulo, AritAs. 320 p. 
CONTAG. Questões Agrärias. Doc. 8. O Estatuto da l'erra e Decretos Regulamentares.

CUNHA, T.I., 1978. Participasão Social e Estratificąão numa Perspectiva de Intervenção em Comunidades Rurais. Tese de Mestrado. ESALQ/USP. Piracicaba, S.P. 119 p.

DEMARTIIJI, Z., de B.F. Uma visão histörico Sociolögica da Edụ cação da População Rural em são Paulo. in: CERU. Caderno n! 15. 1: sërie. São Paulo. p. 7-32.

DUARTE, J.C. e QUEDA, O., 1974. Agricultura e Acumulação. in: Debate \& Critica. II. 90-97.

DIEGUES, M., 1976. Populações Rurais Brasileiras. in: SZMRE CSANYI, T. e QUEDA, O., org. Vida Rural e Mudansa Social 2. edição. São Paulo, Editora Nacional. p. 121-131.

FUKUI, L.F.G. et alii, 1981. A desescolarização, o Trabalho Infantil e a Questão de Menor: Um projeto de Pesquisa. in: CERU Caderno no 15. 1. a sêrie. p. 33-43.

GRAZIAINO da SILVA, J.F., coord. 1978. Estrutura Agrária e Produção de Subsistência na Agricultura Brasizeira. São Paulo, Hucitec. 267 p.

GRILLO, A., 1978. A Terra Tolnida, Escola Rural em Area de Produção Familiar. F.F.C.L. "Barão de Mauä". Ribeirão Preto, são Paulo. 196 p. (Dissertação de Mestrado) . 
GUIMAR̃̃ES, A.P., 1978. A Agricultura Capitalista - uma Perspectiva de Inviabilidade? in: Reforma agräria. Boletim ABRA São Paulo. $6.4-10$.

INCRA/UNICAMP., 1981. Regiões Homogêneas da Agricultura. 1., parte. $290 \mathrm{p}$.

KAUTSKY, K., s/d., A politica do Partido Socialista. COUTINHiO G., trad. São Paulo, Editora Assunção. 195 p.

KAUTSKY, K., 1968. A Questão Agrária. IPEROIG, C. trad. Rio de Janeiro, Editora Laemmert. 325 p.

LANG, A.B.S.G., 1981. Aspirações à Educação, à Ocupação e ao Êxito Social. in: CERU. Caderno no 15. 1. série. p. $45-73$.

LOPES, J.R., 1976. Do Latifündio à Empresa, Unidude $\varepsilon$ Diver sidade do Capitalismo no Campo. São Paulo, CEBRAP. p. 2655 .

MALASSIS, L., 1976. Educação e Desenvolvimento Social. in: SZMRECSANYI, T. e QUEDA, O., Vida Rural e Mudanga Social, 2. edição. São Paulo, Editora Nacional. p. 80-93.

MALASSIS, L., 1975. Ruralité. Education-Developpement. Paris. les Presses de L'Unesco. MASSON Et Cie. lère. Ch. p. 17-33. 
MARTINS, J.S., 1975. A valorização da Escola e do Trabalho no Meio Rural. in: Capitalismo e Tradicionalismo. São Paulo, Pioneira Editora. p. 83-102.

MARX, K., 1980. O Capital. Critica da Economia Politica. o Processo global de produção Capitalista, SANT'ANA, R. trad. Rio de Janeiro, Civilização Brasileira. III - 6 - p. $705-1078$.

MARX, K., 1978. o Capital. Livro I - Cap. VI (Inédito). SuCUPIRA, E.F., trad. São Paulo, Livraria Editora Ciências Humanas Ltda. $151 \mathrm{p}$.

MOLINA FILHO, J., 1977. Unidades de Produção Agrícola no Bra sil. in: O Solo. Piracicaba, SP 1 p. 7-14.

MOLINA, M.I.G., 1970. Migraşão Rural-Rural. Análise Socioló gica da Migrą̧̃a dos Parceleiros do Projeto Iguatemi. Tese de Doutoramento USP/ESALQ. Piracicaba. São Paulo, 188 p.

NEVES, E.M. et alii, 1981. Fatores Sócio-Econômicos que afetam a Escolaridade na Zona Rural do Estado de São Pauro. São Paulo. SE/CENP. 176 p.

PEREIRA, L., 1971. Rencimento e Deficiências do Ensino Primā rio Brasileiro. in: Estudos sobre o Brasil Contemporâneo. São Paulo, Pioneira Editora. p. 179-212. 
PREFEITURA MUNICIPAL DE OSVALDO CRUZ, 1979. Dados Gerais e Histórico do Municipio. Mimeografado.

QUEDA, O. e SZMRECSÃNYI, T., 1976. O Papel da Educação Escolar e da Assistência Técnica. in: SZMRECSÃNyI, T. e QUEDA, O., org. Vida Rural e Mudanşa Social. 2a edição. São Paulo, Editora Nacional. p. 216-233.

RAìGEL, I., 1978. Estrutura Agrária, Sociedade e Estado. in: Reforma Agräria. Boletim ABRA. Campinas, SP 6 p. $25-33$.

RYFF, Y., 1978. Preço da Terra e Acumulação de Capital no Se tor Agrícola. in: Reforma Agräria. Boletim ABRA. Campinas, SP 6 P. 11-17.

SILVA, S., 1976. Expansão Cafeeira e Origens da Indüstria no Brasil. 2a reimpressão. São Paulo, Alfa-Omega. 120 p. SILVA, J., 1978. Resultados e Alternativas da Política de De senvolvimento - A Questão da Reforma Agrária. in: Refor ma Agräria. Boletim ABRA. Campinas. SP 6 p. 46-51.

STAVENHAGEN, R., 1976. A Comunidade Rural nos Paises Subdesenvolvidos, in: SZMRECSANYI, T. e QUEDA, O., org. Vida Rural e Mudansa Social. 2a edição. São Paulo, Editora Nacional, p. 26-38. 
STINCFOMBE, A.L., 1976. Classes Rurais e Meio Rural. in: SZMRECSANYI, T. e QUEDA, O., Org. Vida Rural e Mudanga Social. 2a edição. São Paulo, Editora Nacional. p. 3956 .

TOMPKIN, J.R. Estatistica e Métodos de Pesquisa em Ciências Sociais Rurais. Conv. USAID/B OSU/ESALQ. Piracicaba. SP. Brasil. Parte 1. Mimeografado. p. 39-57.

TOSCANO, G., 1976. Evolução e Composição da População Agrỉco la no Estado de São Paulo. in: Agricultura em São Paulo. Boletim do IEA. ano XXIII - I. p. 191-213.

WANDERLEYY, M.N.B., 1979. Capital e Propriedade Fundiāria na Agricultura Brasileira. in: WANDERLEY, M.N.B. et alii. Reflexões sobre a Agricultura Brasileira. Rio de Janeiro, Paz e Terra. p. 15-40.

WANDERLEY, M.N.B., 1979. Capital e Propriedade Fundiáriasuas Articulasões na Economia Aqucareira de Pernambuco. Rio de Janeiro, Paz e Terra. 145 p. 
.182 .

A NE $X 0 \mathrm{~S}$ 
ANEXO I

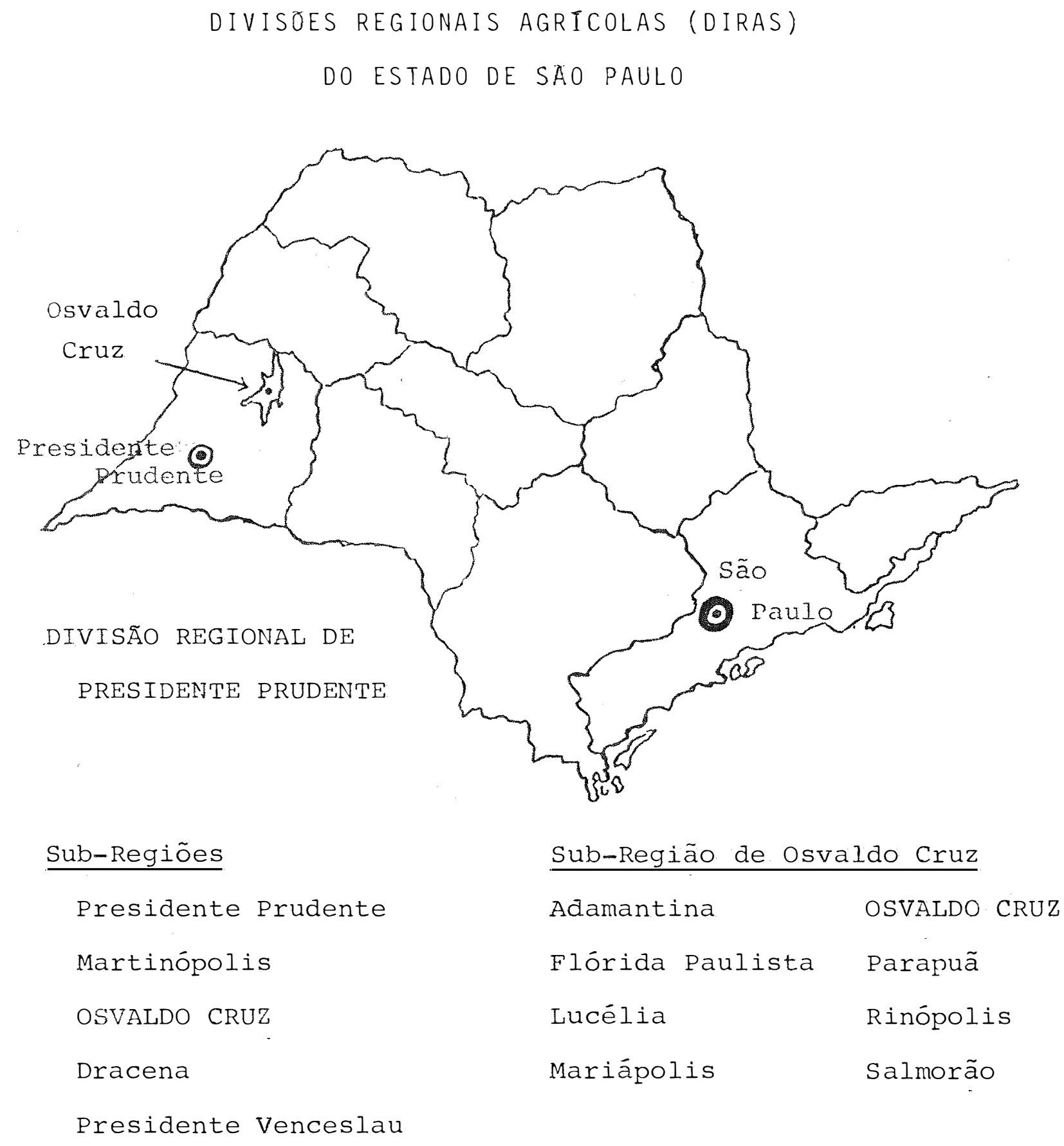


ANEXO II

UNIDADE 1 - UNIDADE PRODUTIVA - Data da Coleta

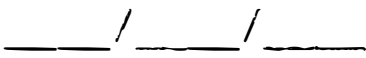

NOME DA UNIDADE (Fazenda, Sítio, Chácara)

01. Área da Unidade: algueires paulistas ha

02. Condição do Declarante: Proprietário ( ); Arrendatário( ); Administrador ( ); Parceiro ( ); Empreiteiro ( ); Assalaraiado com direito à terra ( ); Colono ( ); Outros ( ).

03. O Proprietário tem outras fazendas (sítios ou chácaras) a lém desta? Sim ( ); Não ( ). Se tem, quantas possui: no Municipio Fora do Município Fora do Estado

04. Se o Declarante é arrendatário, parceiro, colono, etc., quais as condições de pagamento da terra?

05. Residência do Declarante: na área ( ); na sede do Município ( ); no bairro rural ( ); fora do Município ( ); fora do Estado ( ).

06. Residência do proprietário: na área ( ); no Município( ); fora do Município ( ); fora do Estado ( ).

07. Presença do Responsável pela exploração: constante ( ); vem algumas horas por dia ( ); algumas horas por mês ( ); vem todas as semanas ( ); todo mês ( ); alguns dias por ano ( ).

08. Tecnologia: são utilizadas máquinas na lavoura? Sin ( ); Não. ( ). Se sim, quais?

09. Sendo usadas maquinas, elas são: propriedade da Unidade ( ); alugadas ( ); cedidas por empréstimo ( ). 
10. A Unidade Produtiva recebe Assistência Técnica de quem? Agrónomo: próprio ( ); da Casa da Agricultura ( ); da Casa da Lavoura ( ); da Cooperatura Agrícola ( ) ; do Banco, quando vem inspecionar a lavoura por causa do empréstimo que vai ser, ou foi concedido ( ); de Veterinario da Casa da Agricultura ( ); da Casa da Lavoura ( ); particular, com pagamento de consulta ( ); de Técnico Agrícola ( ) ; Outros ( ).

11. Quais as lavouras e criações exploradas? Lavoura Area/pés; cabeças Valor da porção Valor da por-

\begin{tabular}{|c|c|c|c|}
\hline Culti- & Dúzias & vendida em & ção consumida \\
\hline vada & Litros & $1980 / 1981$ & $1980 / 1981$ \\
\hline \\
\hline & & & \\
\hline & & & \\
\hline Arroz & & 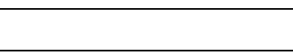 & \\
\hline Feijão & & 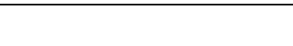 & \\
\hline & & & \\
\hline \multicolumn{4}{|l|}{ Pecuāria } \\
\hline \multicolumn{4}{|l|}{ Aves/ovos } \\
\hline \multicolumn{4}{|l|}{ Vacas / } \\
\hline Porcos & & & \\
\hline Cutros & & & \\
\hline
\end{tabular}

12. Mão-de-Obra

a: Eamílias? Sim ( ); Não ( ). Se sim, quantas? São residentes? Sirr ( ); nJão ( ). Quantos Adultos trabalham na Unidade? Homens $\underline{\mathrm{Mu}}$ Iheres Quantos fienores? 
b. Faixa etária dos Menores:

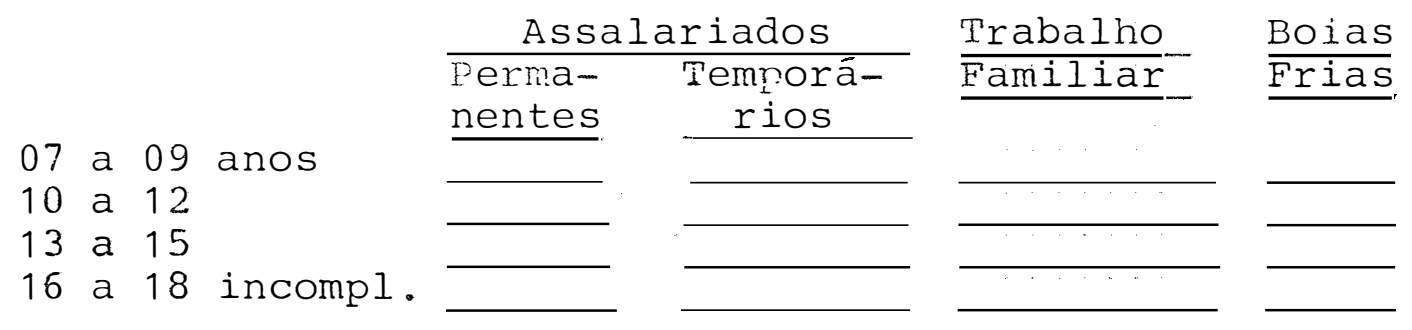

c. Boias-Frias:

Adultos: quantos em média: na safra? Menores: quantos em média: na safra?

Salário Cr na entre-safra?

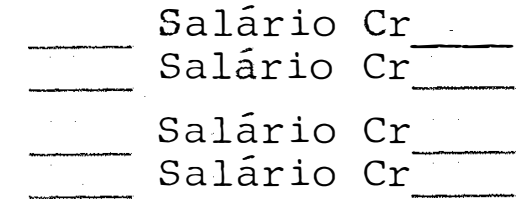

d. Assalariados Adultos:

Permanentes: cquantos Temporários:quantos
Nivel Salarial Cr Nível Salarial C a $\mathrm{Cr}$ a $\mathrm{Cr} \longrightarrow$

13. Tarefas Agrícolas necessárias às duas principais explorações:

a. café

capina

adubação solar

plantio

arruação

esparrama

adubação foliar

colheita

beneficiamento

b.

capina

adubação solar

plantio

tratos culturais

Adubação foliar

Colheita
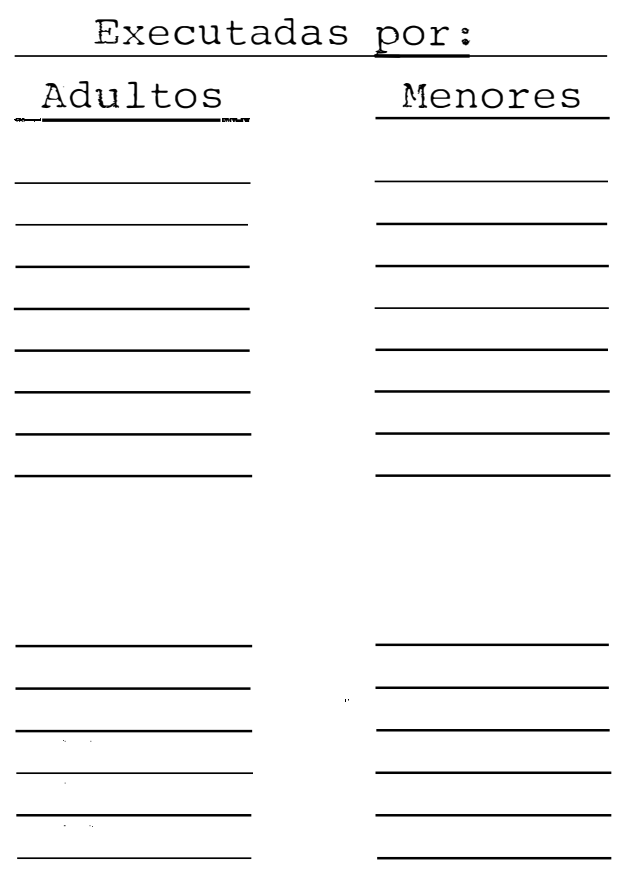
14. A Administração:

a. econômico-financeira é feita pelo proprietário ( ); pẹ lo Administrador ( ); Arrendatário ( ); Parceiro ( ); Outros ( ) .

b. da organização do trabalho, distribuição de tarefas de funções, é feita: pelo Proprietário ( ); Administra dor ( ); Arrendatário ( ); Parceiro ( ); Outros ( ).

15. Já fez empréstimos bancários alguma vez? Sim ( ); Não ( ). Se já fez, foi ocasionalmente? $\operatorname{Sim}($ ) ; Não ( ) ; faz anual mente? Sim ( ); Não ( ). Para que fim é feito o empréstí mo? Custeio ( ); compra de maquinas ( ); compra de imunizantes ( ). OBSERVAÇÕES

16. Uso de insumos (imunizantes e outros): são usados habitualmente ( ); raramente ( ); só na época do plantio ( ); não são usados produtos químicos ( ) . 
ANEXO II I

UNIDADE 2 - PAIS (que tenham

filhos em idade escolar)

Data da Coleta

01. Nome da Unidade Produtiva

02. PROPRIETARIO

03. Dados familiares

\begin{tabular}{|c|c|c|c|c|c|c|c|c|}
\hline \multirow{2}{*}{$\begin{array}{l}\text { Membro da } \\
\text { familia e } \\
\text { outras pes } \\
\text { soas resi- } \\
\text { dentes }\end{array}$} & \multirow[b]{2}{*}{$\begin{array}{c}0 \\
0 \\
0 \\
0 \\
0 \\
0\end{array}$} & \multirow[b]{2}{*}{$\mid \begin{array}{c}0 \\
0 \\
0 \\
0 \\
0 \\
1-1 \\
1 \\
\end{array}$} & \multirow[b]{2}{*}{ 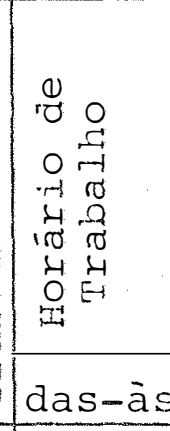 } & \multicolumn{3}{|c|}{ ESCOLARIDADE } & \multirow[t]{2}{*}{ SALĀRIO } & \multirow{2}{*}{$\begin{array}{c}\text { OBSERVA- } \\
\text { ÇÕES }\end{array}$} \\
\hline & & & & 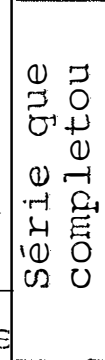 & 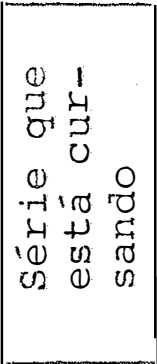 & 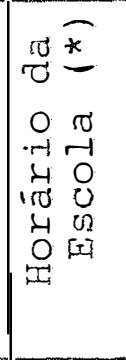 & & \\
\hline \multicolumn{9}{|l|}{ Pai } \\
\hline \multicolumn{9}{|l|}{ Mãe } \\
\hline \multicolumn{9}{|l|}{ Filhos: } \\
\hline & & & & & & & & \\
\hline & & & & & & & & \\
\hline & & & & & & & & \\
\hline & & & & & & & & \\
\hline & & & & & & & & \\
\hline & & & & & & & & \\
\hline $\begin{array}{l}\text { Outras pes } \\
\text { soas }\end{array}$ & & & & & & & & \\
\hline & & & & & & & & \\
\hline & & & & & & & & \\
\hline
\end{tabular}


05. O senhor quer que seu filho(a) continui a estudar depois que terminar a 4 ạ série? (ou a 3 ạ série) $\operatorname{Sim}($ ); rvão ( ). Se quer, porque, ou para quê deseja que ele(a) continui a estudar?

Até que série quer que ele(a) estude? 1\% Grau 2. Grau Curso Técnico completo Faculdade

06. Que profissão o senhor deseja para seu filho(a) que estuda?

07. Se algum filho(a) parou de estudar, porque parou?

08. O horário da Escola dos seus filhos é bom? $\operatorname{Sim}($ ); rãa( ). Seria melhor se fosse outro? $\operatorname{Sim}($ ): Não ( ). Qual?

09. O senhor acha que os meses de férias escolares foram bem escolhidos? $\operatorname{Sim}($ ); Não ( ). Porque?

Seria melhor se as férias fossem dadas em outro tempo?

$\operatorname{Sim}($ ); Não ( ) . Qual?

10. O senhor já conversou com o Professor(a) de seu filho(a)? Sim ( ); Não ( ); de vez em quando ( ); muitas vezes ( ); conversa sempre ( ). OBSERVAÇOES

11. Já foì à Escola de seu filho(a) alguma vez? $\operatorname{Sim}($ ) ;Não( ). Porque foi ou não foi? 
12. MIGRAÇÃO: lugares em que a família morou nos últimos cin co anos.

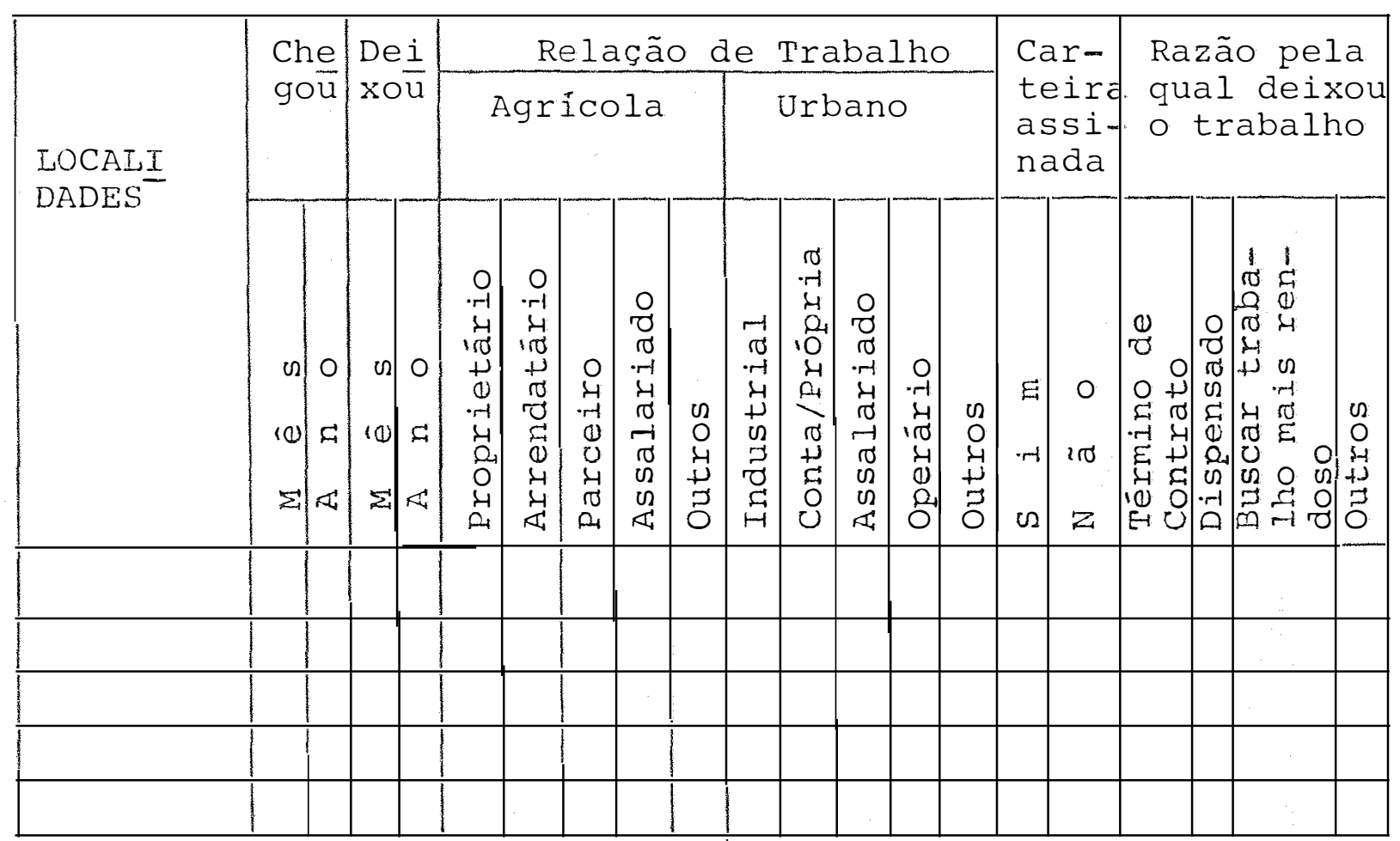

13. As mudanças de moradia e de trabalho têm atrapalhado o es tudo dos filhos? Sim ( ); Não ( ). Porque sim,ou porque não?

14. O senhor acha que vale a pena ficar bastante tempo em um Iugar para os filhos poderem estudar? $\operatorname{Sim}($ ) ; Não ( ). Porque sim ou porque não?

15. A sua familia costuma ir à cidade para: Compras ( ); Visi tas (); Passeios ( ); Frequentar a Igreja ( ).

Vai à cidade: todas as semanas ( ); uma vêz por mês ( ); raramente (); todos os dias ( ). 
16. Vocês costumam em casa: ler jornal ( ); ouvir rádio ( ); ver Televisão ( ); Quais os programas de rádio ou de TV de que mais gostam?

17. O senhor gostaria de morar na cidade? $\operatorname{Sim}($ ); Não ( ); Por que?

(assinatura do entrevistador para controle) 
ANEXO IV

UNIDADE 3 - MENOR TRABALHADOR - Data da Coleta

01. Identificação geral do Menor:

Idade anos; Sexo: Masc. ( ); Fem. ( ).

02. Com quantos anos você começou a trabalhar?

03. Quantas horas você trabalha por dia?

04. Qual o trabalho que você faz?

05. Quanto você ganha? Cr\$

Quem recebe o dinhei ro do seu trabalho? Se é você quem recebe o dinheiro, você o entrega todo para a família? Sim( );Não( ). Em parte ( ).

06. Você gosta do trabalho que faz? $\operatorname{Sim}($ ); Não ( ). OBSERVAÇÕES

07. Você gostaria de fazer outro trabalho? $\operatorname{Sim}($ ); Não ( ) . Se você pudesse, que trabalho gostaria de fazer?

08. Você está na Escola? $\operatorname{Sim}($ ); Não ( ). Se está, em que sế rie está?

09. Você já esteve na Escola? Sim ( ); Não ( ). Até que série você estudou ou parou de estudar? Quantos anos você estudou? ___ Sabe ler e escrever? $\operatorname{Sim}($ ); Não ( ). Se você saiu da Escola, por que saiu? 
10. Se você saiu da Escola, tem vontade de voltar? $\operatorname{Sim}($ ); Não ( ). Por que?

11. Você quer ficar sempre trabalhando na fazenda? $\operatorname{Sim}(1)$; Não ( ). Por que?

12. Se você quer sair daqui, para onde deseja ir? Para outra fazenda ou sitio (); Para a cidade ( ). Por que?

(assinatura do entrevistador, para controle) 
ANEXO V

UNIDADE 4 - ESCOLA

Data da Coleta:

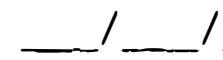

01. Nome da Escola

02. Tipo da Escola: Emergência ( ); Isolada ( ); Agrupada ( ); Outros ( ).

03. Número de Professores

04 . Horários

a. Funcionamento: manhã ( ); tarde ( )

b. O horário favorece a frequência dos alunos? Sim ( ); Não ( ). Por que?

c. É horário adequado às possibilidades do Professor? $\operatorname{Sim}($ ); Não ( ). Por que?

05. Condições da Escola:

a. Construção e Conservação:

Alvenaria ( ); Madeira ( ); Iluminação: Boa ( ); Má( ); Rachaduras:Sim( ); Não ( ). Goteiras: $\operatorname{Sim}($ ); Não ( ); Pintura: limpa e conservada ( ); desgastada, necessitando reparos ( ).

b. Condições de Higiene

Água: de fonte, encanada ( ); de poço, com bomba ( ); de poço, sem bomba ( ); filtrada ( ); não filtra da ( ).

Fossa sanitária:

com vaso de louça ( ); vaso de caixote ( ); sem vaso e em condições precárias ( ); sem vaso, mas limpo ( ).

c. Recursos:

Quadro negro: fixo ( ); móvel ( ). Mapas cartográficos: $\operatorname{Sim}($ ); Não ( ).

Carteiras: individuais (); para dois alunos ( ). Armário: Sim ( ); Não ( ). 
d. Número de salas de aula E suficiente ( ); Insuficiente ( ); salas fora de uso - quantas? Sala reservada para o preparo da merenda? $\operatorname{Sim}($ ); Não ( ).

06. Número de alunos; 1 a $2 a$ 3 ạ 4 a 5 a 6 a

07. Acesso à Escola:

$$
\begin{aligned}
& \text { Para os alunos } \\
& \text { Fácil Difícil Muito }
\end{aligned}
$$

\begin{tabular}{ccc}
\multicolumn{3}{c}{ Para o Professor } \\
Fácil & Dificil & $\begin{array}{c}\text { Muito } \\
\text { dificil }\end{array}$ \\
( ) & $(1)$ & $(1)$ \\
( ) & $(1)$ & $(1)$
\end{tabular}

$\begin{array}{lllllll}N a \text { seca } & (1) & (1) & (1) & (1) & (1) & (1) \\ N a \text { chuva } & (1) & (1) & (1) & (1) & (1) & (1)\end{array}$

08. Quantos alunos trabalham em tarefas agrícolas?

Habitualmente? Na safra

09. Frequência dos alunos:

\begin{tabular}{ll}
\multicolumn{1}{c}{ M é s } & \\
Fevereiro & \\
Março & \\
Abril & \\
Maio & \\
Junho & \\
Agosto & \\
Setembro &
\end{tabular}

Causas das ausências

10. A Escola oferece aos alunos outros serviços além do Ensino? Merenda Escolar ( ); Outros ( ). Quais?

11. A Escola mantém algum Programa para a Comunidade? Sim ( )i Não ( ). Se mantém, dizer quais são estes Programas? 
12. Professor (para cada Professor entrevistado na Escola) Formação: Professor nível I ( ); Professor nível II ( ); Pedagogia? ( ); Especialização? ( ) ; Outros Cursos ( ) Quais?

Possui formação para a agricultura? Sim ( ); Não ( ) . Situação Funcional: efetivo ( ); não efetivo ( ); Estagiáa rio ( ); Substituto ( ). Há quanto tempo dá aulas nesta Escola? de

a

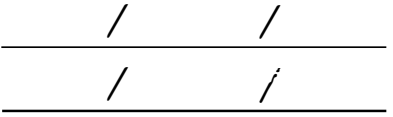

Onde lecionou nos últimos cinco anos?

Nome da Escola

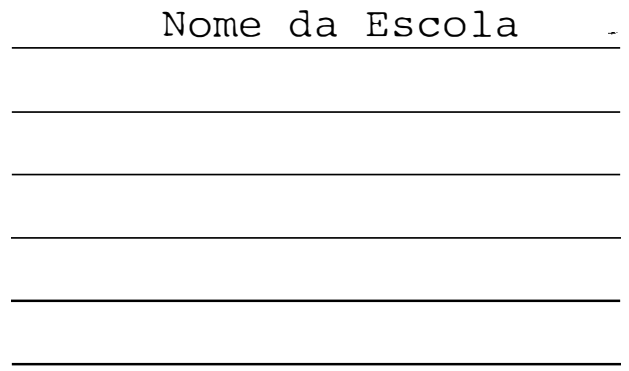
- Municipio Tempo de Exercício

Quais os programas que segue no Ensino?

Organiza atividades extra-classe? $\operatorname{Sim}($ ) ; Não ( ). Se or ganiza, qual o tipo de atividades?

Procura manter contato com os pais dos alunos? Sim ( ); Não ( ). Se procura, como mantém tais contatos? 
ANEXO VI

UNIDADE 5 - MENOR ESCOLAR (alunos) - Data da Coleta

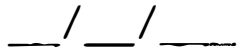

01. Escola

02. Identificação geral do Menor: Idade anos; Sexo: Masc. ( ); Fem. ( ). Série

03. Por que o seu Pai ou sua Mãe o colocaram na Escola?

04. Você falta às aulas? muitas vezes ( ); poucas vezes ( ); nunca falta ( ). Se você falta às aulas, qual o motivo ? distância muito grande ( ); trabalho na roça ( ); fica cuidando dos irmãos ( ); doenças ( ); fica fazendo trabalho em casa; lavar roupa ( ); cozinhar ( ); Não gosta da Escola ( ).

05. Você gosta de vir à Escola? Sim ( ). Por que? Não ( ). Por que?

06. Do que você gosta mais em relação ao que você aprende na Escola?

07. Do que você gosta menos (ou não gosta) em relação ao que você aprende na Escola?

08. Até que série você quer cursar?

09. O que você gostaria de ser quando crescer?

10. Você faz alguma coisa mais do que vir à Escola e estudar? Sim (1); Não ( ). Se faz, o que você faz? brinca ( ) tra balha ( ). Se você trabalha, que trabalho você faz?

Se você trabalha, o faz durante o ano todo? ( ); só alguns meses (); somente em alguns dias do ano ( ). 
11. Seus pais mudam muito de uma fazenda para outra? Sim ( ); Não ( ). Se mudam, quantas vezes você já mudou nos últimos três anos?

12. Você pode dizer o que você sabe daquilo que aprendeu na Escola?

13. O que você acha que é mais importante: o trabalho que você faz na roça ( ); o trabalho que você faz em casa ( ) ; o trabalho ou estudo da Escola ( ).

Por que você acha mais importante o trabalho que escolheu entre estes?

14. De onde você gosta mais? da roça ( ). Por que?

Da cidade? ( ). Por que?

(assinatura do entrevistador, para controle) 